\title{
Лимфома Ходжкина
}

\section{Клинические рекомендации}

Е.А. Демина', Г.С. Тумян ${ }^{2,3}$, Т.Н. Моисеева ${ }^{4}$, Н.Б. Михайлова ${ }^{5}$, Н.В. Мякова ${ }^{6}$, А.Г. Румянцев ${ }^{6}$, А.А. Масчан ${ }^{6}$, К.Д. Капланов ${ }^{7,8}$, Р.Г. Шмаков ${ }^{9}$, Н.А. Фалалеева ${ }^{10}$, В.В. Птушкин ${ }^{11}$, Е.А. Османов ${ }^{3,12}$, И.В. Поддубная" ${ }^{2}$ В.В. Байков А.М. Ковригина ${ }^{4,13}$, Д.М. Коновалов ${ }^{6}$, О.П. Трофимова ${ }^{2,3}$, В.М. Сотников ${ }^{14}$, Н.В. Ильин ${ }^{15}$, Ю.Н. Виноградова ${ }^{15}$, А.В. Нечеснюк 6 , Р.А. Пархоменко ${ }^{14}$, Д.Н. Стефанов ${ }^{6}$, А.А. Невольских ${ }^{10}$, С.А. Иванов ${ }^{10}$, Ж.В. Хайлова ${ }^{10}$, Т.Г. Геворкян ${ }^{3}$ 'ФГБУ «Национальный медико-хирургический центр им. Н.И. Пирогова» Минздрава России, Москва, Россия; 2ФГБОУ ДПО «Российская медицинская академия непрерывного просрессионального образования» Минздрава России, Москва, Россия;

${ }^{3}$ ФБУ «Национальный медицинский исследовательский центр онкологии им. Н.Н. Блохина» Минздрава России, Москва, Россия; "ФГБУ «Национальный медицинский исследовательский центр гематологии», Москва, Россия; ${ }^{5}$ ГБОУ ВО «Первый Санкт-Петербургский государственный медицинский университет им. акад. И.П. Павлова» Минздрава России, Санкт-Петербург, Россия;

${ }^{6}$ ФГБУ «Национальный медицинский исследовательский центр детской гематологии, онкологии и иммунологии им. Дмитрия Рогачева» Минздрава России, Москва, Россия;

7ГБУЗ «Волгоградский областной клинический онкологический диспансер», Волгоград, Россия;

${ }^{8}$ ФГБОУ ВО «Волгоградский государственный медицинский университет» Минздрава России Волгоград, Россия; ${ }^{9}$ ФББУ «Национальный медицинский исследовательский центр акушерства, гинекологии и перинатологии им. акад. В.И. Кулакова» Минздрава России, Москва, Россия;

${ }^{10}$ Медицинский радиологический научный центр им. им. А.Ф. Цыба - филиал ФГБУ «Национальный медицинский исследовательский центр радиологии» Минздрава России, Обнинск, Россия;

"ГБУЗ «Городская клиническая больница им. С.П. Боткина», Москва, Россия;

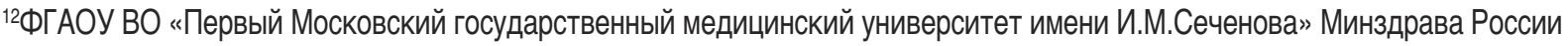
(Сеченовский Университет), Москва, Россия;

${ }^{13}$ Академия постдипломного образования ФГБУ ФНКЦ ФМБА России, Москва, Россия;

${ }^{14}$ ГБУ «Российский научный центр рентгенорадиологии» Минздрава России, Москва, Россия;

${ }^{15}$ ФБУ «Российский научный центр радиологии и хирургических технологий им. акад. А.М. Гранова» Минздрава России, Санкт-Петербург, Россия;

Для цитирования: Лимфома Ходжкина. Клинические рекомендации. Современная Онкология. 2020; 22 (2): 6-33. DOI: $10.26442 / 18151434.2020 .2 .200132$

\section{Guidelines}

\section{Hodgkin Lymphoma}

\section{Clinical recommendations}

Elena A. Demina', Gaiane S. Tumian ${ }^{2,3}$, Tatiana N. Moiseeva ${ }^{4}$, Natalia B. Mikhailova ${ }^{5}$, Natalia V. Miakova ${ }^{6}$, Aleksandr G. Rumiantsev ${ }^{6}$, Aleksei A. Maschan ${ }^{6}, K^{2}$ Kall' D. Kaplanov $^{7,8}$, Roman G. Shmakov $^{9}$, Natalia A. Falaleeva ${ }^{10}$, Vadim V. Ptushkin"1, Evgenii A. Osmanov ${ }^{3,12}$, Irina V. Poddubnaia ${ }^{2}$, Vadim V. Baikov ${ }^{5}$, Alla M. Kovrigina ${ }^{4,13}$, Dmitrii M. Konovalov ${ }^{6}$, Oksana P. Trofimova ${ }^{2,3}$, Vladimir M. Sotnikov ${ }^{14}$, Nikolai V. I''in ${ }^{15}$, Yulia N. Vinogradova ${ }^{15}$, Aleksei V. Nechesniuk 6 , Roman A. Parkhomenko ${ }^{14}$, Dmitrii N. Stefanov ${ }^{6}$, Aleksei A. Nevol'skikh ${ }^{10}$, Sergei A. Ivanov ${ }^{10}$, Zhanna V. Khailova ${ }^{10}$, Tigran G. Gevorkian ${ }^{3}$

'Pirogov National Medical and Surgical Center, Moscow, Russia;

${ }^{2}$ Russian Medical Academy of Continuous Professional Education, Moscow, Russia;

${ }^{3}$ Blokhin National Medical Research Center of Oncology, Moscow, Russia;

${ }^{4}$ National Research Center for Hematology, Moscow, Russia;

${ }^{5}$ Pavlov First Saint Petersburg State Medical University, Saint Petersburg, Russia; 
${ }^{6}$ Dmitriy Rogachev Federal Research Center of Pediatric Hematology, Oncology and Immunology, Moscow, Russia;

'Volgograd Regional Clinical Oncology Center, Volgograd, Russia;

${ }^{8}$ Volgograd State Medical University, Volgograd, Russia;

${ }^{9}$ Kulakov National Medical Research Center for Obstetrics, Gynecology and Perinatology, Moscow, Russia;

${ }^{10}$ Tsyb Medical Radiological Research Center - branch of the National Medical Research Radiological Center, Obninsk, Russia;

${ }^{11}$ Botkin City Clinical Hospital, Moscow, Russia;

${ }^{12}$ Sechenov First Moscow State Medical University (Sechenov University), Moscow, Russia;

${ }^{13}$ Postgraduate Academy Federal Scientific and Clinical Center for Specialized Types of Medical Assistance and Medical Technologies

of the Federal Biomedical Agency, Moscow, Russia;

${ }^{14}$ Russian Scientific Center of X-ray Radiology, Moscow, Russia;

${ }^{15}$ Granov Russian Scientific Center of Radiology and Surgical Technology, Saint Petersburg, Russia

For citation: Hodgkin Lymphoma. Clinical recommendations. Journal of Modern Oncology. 2020; 22 (2): 6-33.

DOI: $10.26442 / 18151434.2020 .2 .200132$

Международная классификация болезней 10-го пересмотра: С.81

Год утверждения (частота пересмотра): 2020

ID: KP139/1

Профессиональные ассоциации:

- Общероссийский национальный союз «Ассоциация онкологов России»

- Региональная общественная организация «Общество онкогематологов»

- Некоммерческое партнерство содействия развитию гематологии и трансплантологии костного мозга «Национальное гематологическое общество»

- Региональная общественная организация «Национальное общество детских гематологов и онкологов»

Одобрено Научно-практическим советом Минздрава России

\section{Оглавление}

Ключевые слова

Список сокращений

Термины и определения

1. Краткая информация

2. Диагностика

3. Лечение

4. Реабилитация

5. Профрилактика

6. Дополнительная информация, влияющая на течение

и исход заболевания
Критерии оценки качества медицинской помощи

Список литературы

Приложение А1. Состав рабочей группы

Приложение А2. Методология разработки клинических

рекомендаций

Приложение АЗ. Связанные документы

Приложение Б. Алгоритмы ведения пациента

Приложение В. Информация для пациентов

Приложение Г

Ключевые слова: лимфома Ходжкина, клинические рекомендации.

\section{Список сокращений}

АЛТ - аланинаминотрансфераза

АСТ - аспартатаминотрансфераза аутоТГСК - аутологичная трансплантация гемопоэтических стволовых клеток

ВДХТ - высокодозная химиотерапия

ВОЗ - Всемирная организация здравоохранения

Г-КСФ - гранулоцитарно-макрофагальный колониестимулирующий фактор (L03AA)

ГСК - гемопоэтические стволовые клетки кЛХ - классическая лимфома Ходжкина КТ - компьютерная томография

ЛДГ - лактатдегидрогеназа

лТ - лучевая терапия

лХ - лимсома Ходжкина

МПИ - Международный прогностический индекс

\section{Термины и определения}

ECOG - оценка общего состояния пациента по шкале, разра-

ботанной Восточной объединенной онкологической группой (Eastern Cooperative Oncology Group) - см. приложение Г1.
MPТ - магнитно-резонансная томография НЛПЛХ - нодулярная с лимфоидным преобладанием ЛХ

ОАК - общий анализ крови

ПР - полная ремиссия

ПХТ - полихимиотерапия

ПЭТ - позитронно-эмиссионная томография

ПЭТ/КТ - ПЭТ, совмещенная с КТ

РФП - радиофармпрепарат

СОД - суммарная очаговая доза

СОЭ - скорость оседания эритроцитов

Т4 - тироксин

ТТГ - тиреотропный гормон

УдД - уровень достоверности доказа-

тельств

УЗИ - ультразвуковое исследование

УУР - уровень убедительности рекомендаций
ФВД - функция внешнего дыхания

ХТ - химиотерапия

чР - частичная ремиссия

ЭКГ - электрокардиография

ЭхоКГ - эхокардиография

GTV - макроскопический объем опухоли

CTV - клинический объем мишени

PTV - планируемый объем мишени

$\mathrm{lg}$ - иммуноглобулин

** - жизненно необходимые и важнейшие лекарственные препараты

\# - препарат, применяющийся не в соответствии с показаниями к применению и противопоказаниями, способами применения и дозами, содержащимися в инструкции по применению лекарственного препарата (офф-лейбл)
В-симптомы - неспецифические симптомы опухолевой интоксикации, включающие лихорадку выше $38^{\circ} \mathrm{C}$ не менее 3 дней подряд без признаков воспаления; ночные профузные поты; похудение на 10\% массы тела за последние 6 мес. 


\section{1. Краткая информация}

1.1. Определение заболевания или состояния (группы заболеваний или состояний)

Лимфома Ходжкина (ЛХ) - это В-клеточное злокачественное лимфопролиферативное заболевание [1].

\section{2. Этиология и патогенез заболевания или} состояния (группы заболеваний или состояний)

Этиология ЛХ неизвестна. К опухолевой популяции ЛХ относят клетки Ходжкина, клетки Рид-Штернберга, лакунарные, мумифицированные, LP-клетки. ЛХ характеризуется выраженным реактивным полиморфноклеточным микроокружением [1].

\section{3. Эпидемиология заболевания или состояния} (группы заболеваний или состояний)

Заболеваемость ЛХ в России составляет 2,2 случая на 100 тыс. населения в год, смертность достигает 0,61 случая на 100 тыс. населения в год (в 2016 г. впервые выявлено у 3129 человек, умерли 879 человек). Заболевание возникает в любом возрасте, но преимущественно в интервале 16-35 лет, в этой возрастной группе в России среди заболевших преобладают женщины [2].

\section{4. Особенности кодирования заболевания или состояния (группы заболеваний или состояний) по Международной статистической классификации болезней и проблем, связанных со здоровьем} С81. ЛХ.

- С81.0. Нодулярный тип лимфоидного преобладания ЛХ.

- С81.1. Нодулярный склероз (классической) ЛХ.

- С81.2. Смешанно-клеточный вариант (классической) ЛХ.

- C81.3. Лимфоидное истощение (классической) ЛХ.

- C81.4. Лимфоцитарная (Lymphocyte-rich) (классическая) ЛХ.

- С81.7. Другие формы (классической) ЛХ.

- С81.9. ЛХ неуточненная.

https://doi.org/10.26442/18151434.2020.2.200167

\section{2. Диагностика}

Многие рекомендованные методы диагностики заболевания и связанных с ним состояний имеют ограниченную доказательную базу (в соответствии с шкалами оценки уровня достоверности доказательств - Удд и уровня убедительности рекомендации - уур по причине отсутствия посвященных им клинических исследований. Невзирая на это, они являются необходимыми элементами обследования пащиента для установления диагноза и выбора тактики лечения, так как более эффективные и доказанные методы в настоящее время не разработаны.

Критерии установления диагноза/состояния: диагноз ЛХ устанавливается на основе морфологического и иммуногистохинического исследования биопсийнго материала и формулируется в соответствии с пересмотренной классификацией опухолей гемопоэтической и лимфоидной тканей ВОЗ 2017 2. [1,3].

\section{1. Жалобы и анамнез}

- У всех пациентов с подозрением на ЛХ или выявленной ЛХ при первичном приеме рекомендуется сбор анамнеза при заболеваниях органов кроветворения и крови [4]. УУР С (УДД 5).

Комментарии: при сборе анамнеза необходимо уточнять в том числе семейный анамнез, обрамая внимание на наличие лимфопролиферативных заболеваний.

- У всех пациентов с подозрением на ЛХ или выявленной ЛХ при первичном или повторном приеме, перед каждым последующим циклом химиотерапии (XT), при оценке ремиссии через 2 мес после завершения терапии, при контрольных обследованиях и при подозрении на реци-

\section{5. Классификация заболевания или состояния} (группы заболеваний или состояний)

В пересмотренной классификации опухолей гемопоэтической и лимфоидной тканей Всемирной организации здравоохранения (ВО3) 2017 г. выделяют 2 типа ЛХ: классическую ЛХ - кЛХ (по Международной классификации болезней - МКБ-10 С81.1-С81.9) и нодулярную с лимфоидным преобладанием ЛХ - НЛПЛХ (по МКБ-10 - С81.0. Нодулярный тип лимфоидного преобладания ЛХ). кЛХ включает следующие гистологические варианты: вариант с нодулярным склерозом (1 и 2-го типа), смешанно-клеточный вариант, классический вариант с большим количеством лимфоцитов и редко встречающийся вариант с лимфоидным истощением (морфологическая и иммуногистохимическая диагностика различных вариантов ЛХ - см. раздел 6.1) [3].

Кроме определения типа ЛХ и гистологического варианта кЛХ, у каждого пациента должна быть определена стадия заболевания, а для кЛХ также группа риска [4].

\section{6. Клиническая картина заболевания \\ или состояния (группы заболеваний \\ или состояний)}

Клинические симптомы заболевания могут включать следующие [4]:

- бессимптомное увеличение периферических лимфоузлов;

- симптомы интоксикации (В-симптомы - лихорадка выше $38^{\circ} \mathrm{C}$ не менее 3 дней подряд без признаков воспаления; ночные профузные поты; похудение на 10\% массы тела за последние 6 мес);

- интермиттирующая лихорадка;

- кожный зуд до расчесов;

- у пациентов с массивным поражением средостения - боль в груди, кашель, одышка, симптомы сдавления верхней полой вены.

див заболевания рекомендуется сбор жалоб при заболеваниях органов кроветворения и крови [4].

УУР С (УДД 5).

Комментарии: при первичном осмотре особый акцент необходимо делать на сроки и телпы увеличения лимфоузлов (основной сииптом ЛХ - лимфаденопатия, развиваюомаяса постепенно и асимлетрично), неспецифические силптомы интоксикации (лихорадка выше $38^{\circ} \mathrm{C}$ не менее 3 дней подряд без признаков воспаления; ночные профузные поты; похудение на 10\% массы тела за последние б мес), сииптомы поражения верхнего средостения (навязчивый непродуктивный кашель, синдром сдавления верхней полой вены, охриплость голоса, дисфбагия, диспноэ).

\section{2. Физикальное обследование}

- У всех пациентов с подозрением на ЛХ или выявленной ЛХ при первичном или повторном приеме, перед каждым последующим циклом ХТ, при оценке ремиссии через 2 мес после завершения терапии, при контрольных обследованиях и при подозрении на рецидив заболевания рекомендуется выполнение визуального осмотра терапевтического, пальпации терапевтической и аускультации терапевтической для уточнения распространенности и тяжести течения заболевания [1].

\section{УУР С (УДД 5).}

Комментарий: при осмотре необходимо ощенить общее состояние пациента по шкале ЕСОG (икала, разработанная Восточной объединенной онкологческой группой - Еаstern Cooperative Oncology Group; cм. приложение Г1), а также осмотреть кожные покровы, миндалины и полость рта; пальпащия должна включать в себя пальпащию всех 
доступных групп периферических лимфатических узлов, печени, селезенки.

\section{3. Лабораторные диагностические исследования}

- Всем пациентам с подозрением на ЛХ или выявленной ЛХ при первичном или повторном приеме, после завершения каждого цикла терапии и перед началом каждого нового цикла терапии, при оценке ремиссии после завершения терапии, при контрольных обследованиях и при подозрении на рецидив заболевания рекомендуется для уточнения состояния пациента, планирования терапевтической тактики и определения необходимости ее модификации, а также для определения потребности в сопутствующей и сопроводительной терапии выполнить следующие диагностические исследования [1]:

- общий (клинический) анализ крови (ОАК) развернутый с определением гемоглобина, эритроцитов, тромбоцитов, лейкоцитов, подсчетом лейкоцитарной формулы с оценкой абсолютного содержания лейкоцитов и количества ретикулоцитов, оценкой скорости оседания эритроцитов (СОЭ);

- общий (клинический) анализ мочи;

- анализ крови биохимический общетерапевтический с включением следующих параметров: лактатдегидрогеназа (ЛДГ), мочевина, креатинин, общий белок, альбумин, билирубин, аспартатаминотрансфераза (АСТ), аланинаминотрансфераза (АЛТ), щелочная фосфатаза, калий, натрий, хлор, кальций (другие параметры биохимического анализа крови могут быть включены в исследование на усмотрение врача);

- коагулограмма (ориентировочное исследование системы гемостаза) с включением следующих параметров: протромбин, международное нормализованное отношение, активированное частичное тромбопластиновое время, фибриноген, тромбиновое время, антитромбин III, плазминоген, D-димер.

УУР С (УДД 5).

Комментарий: оценка абсолютного содержания лимфочитов в периферической крови до начала лечения необходима для оптимального выбора ХТ 1-й линии - входит как фактор риска в подсчет числа баллов Международного прогностического индекса (МПИ) для распространенных стадий клХ (см.раздел 6.3).

- Всем ранее не получавшим лечение пациентам с ЛХ перед проведением 1-й линии противоопухолевой терапии рекомендуется определение основных групп крови по системе AB0, определение антигена D системы Резус (резус-фактора) для возможности выполнения гемотрансфузии при наличии показаний до, во время или после терапии [1].

\section{УУР С (УДД 5).}

- Всем ранее не получавшим лечение пациентам с ЛХ перед проведением 1-й линии противоопухолевой терапии рекомендуется для уточнения наличия сопутствующих инфекционных заболеваний и планирования необходимой сопутствующей терапии выполнение следующих исследований:

- молекулярно-биологического исследования крови на вирус гепатита B (Hepatitis B virus) и на вирус гепатита C (Hepatitis $\mathrm{C}$ virus) [1];

- молекулярно-биологического исследования крови на ВИЧ-1 (Human immunodeficiency virus HIV-1);

- молекулярно-биологического исследования крови на вирусы Эпштейна-Барр, цитомегаловирус и вирус простого герпеса.

УУР С (УДД 5).

- Всем пациентам с ЛХ младше 18 лет до начала противоопухолевой терапии, а также всем пациентам с ЛХ, независимо от возраста, получающим или получавшим противоопухолевую терапию, после первого эпизода тяжелой инфекции рекомендуется определение иммунного статуса (исследование уровня иммуноглобулинов - Ig G, А и М) в крови для уточнения риска развития инфекционных осложнений и необходимости назначения соответствующей профилактики $[5,6]$. УУР С (УДД 5).
Комментарии: если $\operatorname{Ig} G<4$ 2/л, клиниеская ситуащия расиенивается как симптоматическая гипогаммаглобллинеми. В этих случаях показана заместительная терапия Ig (см.раздел 3.9. Сопутствуюоиая и сопроводительная терапия).

- Всем женщинам детородного возраста с впервые выявленной ЛХ, а также с рецидивом ЛХ перед началом терапии рекомендуется выполнение комплекса исследований по определению беременности для коррекции терапевтической тактики и консультации акушера-гинеколога в случае наличия беременности и желания женщины ее сохранить $[1,7]$.

УУР С (УДД 5).

\section{4. Инструментальные диагностические исследования}

- Всем пациентам при установлении диагноза ЛХ, при оценке ответа на лечение, а также при подозрении на рецидив заболевания рекомендуется выполнить компьютерную томографию (КТ) шеи, грудной клетки, органов брюшной полости и малого таза (с контрастированием) для стадирования заболевания и уточнения наличия, размеров и распространенности опухолевых очагов [1].

УУР С (УДД 5).

- Пациентам с противопоказаниями к КТ либо при невозможности выполнения КТ, при установлении диагноза ЛХ, при оценке ответа на лечение, а также при подозрении на рецидив заболевания рекомендуется для стадирования заболевания и уточнения наличия, размеров и распространенности опухолевых очагов выполнить следующие диагностические исследования [1]:

- рентгенографию органов грудной клетки в двух проекциях;

- ультразвуковое исследование (УЗИ) лимфатических узлов и внутренних органов.

\section{УУР С (УДД 5).}

Комментарии: при УЗИ необходимо оценить периферические лимфатические узлы, внутрибрюшные, забрюшинные узлы, органы брюшной полости и малого таза. Лимфоузлы диаметром менее 1 см считаются непораженными, лимфоузлы диаметром 1-2 см требуют динамического наблюдения в процессе терапии, лимфоузлы диаметром более 2 см считаются пораженными.

- Всем пациентам при установлении диагноза ЛХ, при оценке ответа на лечение, а также при подозрении на рецидив заболевания рекомендуется при наличии возможности выполнить позитронно-эмиссионную томографию (ПЭТ) всего тела с туморотропными радиофармпрепаратами - РФП (фтордезоксиглюкозой) для более точного стадирования заболевания и лучшей оценки эффекта на терапию $[1,4,8]$.

\section{УУР С (УДД 5).}

Комментарии: ПЭТ, совмещенная с КТ (ПЭТ/КТ), являетса высокоинформативным методом диагностики. ПЭТ/КТ, выполненная до начала лечения, позволяет не только уточнить стадию, но и более точно определить локализаиию очагов поражения, что имеет существенное значение для последующей оценки эфффекта терапии индукции и качественного планирования последующей лучевой терапии (ЛТ) и минимизащии облучения здоровых тканей. При наличии возможности выполнения ПЭТ/КТ она может быть применена в соответствии с переслотренными крите риями оченки ответа, в первую очередь у пациентов с минимальным объемом опухоли, а также с учетом возможной коррекиии лечения.

Необходимо проведение ПЭТ/КТ у пачиентов с ранними стадиями ЛХ, так как это позволит проводить ПЭТ-адаптированную терапию у этих пащиентов.

При наличии технической возможности ПЭТ/КТ должна оцениваться по шкале Deauville (си. приложение Г2).

- Всем пациентам с установленным диагнозом ЛХ, которым планируется лечение по поводу впервые установленного заболевания либо по поводу рецидива, рекомендуется выполнить электрокардиографию (ЭКГ) для уточнения функции сердца $[1,4]$.

УУР С (УДД 5). 
- Всем пациентам с установленным диагнозом ЛХ, которым планируется лечение с использованием противоопухолевого антибиотика доксорубицина** (в схемах ABVD, BEACOPP, OEPA - см. приложение A3.1), а также пациентам со сниженной сердечной функцией, получающим это лечение, рекомендуется выполнить эхокардиографию (ЭхоКГ) с определением фракции сердечного выброса, для контроля кардиологической токсичности [4]. УУР С (УДД 5).

- Всем пациентам с установленным диагнозом ЛХ, которым планируется лечение с использованием противоопухолевого антибиотика блеомицина** (в схемах ABVD и BEACOPP - см. приложение A3.1), а также пациентам со сниженной функцией легких, получающим это лечение, рекомендуется выполнить исследование неспровоцированных дыхательных объемов и потоков (спирография) для контроля пульмональной токсичности [4]. УУР С (УДД 5).

- Всем пациентам с верифицированным диагнозом ЛХ с учетом необходимости назначения глюкокортикоидов рекомендуется перед началом терапии для своевременного выявления сопутствующей патологии и для определения необходимости их профилактики или лечения выполнить следующие исследования [1, 9]:

- эзофагогастродуоденоскопию;

- ультразвуковую допплерографию сосудов (артерий и вен) нижних конечностей. УУР С (УДД 5).

\section{5. Иные диагностические исследования}

Всем пациентам с подозрением на ЛХ, а также всем пациентам с подозрением на рецидив ЛХ (при наличии технической возможности) рекомендуется выполнить биопсию (взятие биопсийного материала) лимфатического узла либо другого очага поражения, патологоанатомическое исследование биопсийного (операционного) материала с применением иммуногистохимических методов для верификации диагноза $[1,4]$.

УУР С (УДД 5).

Комментарии: выбор ткани и объем биопсии должны быть адекватны поставленной диагностической задаче.

- Тонкоигольные биопсии лимфоидной ткани могут быть диагностически значимыми, но не всегда.

- Краевые биопсии лимфоидной ткани мало информативны.

- Фрагментация материала крайне затрудняет его оценку.

- Желательно согласование объема биопсии с патологом.

- Крайне желательно присутствие патолога при биопсии.

- Материал для патологоанатомического исследования должен быть помешен в фиксируюшую среду как можно быстрее. Нельзя допускать высыхания материала.

- Соотношение объема фиксирующей среды к объему фиксируемого объекта не менее чем 10:1.

- Время фиксации не должно быть менее 12 и более 48 ч. Неадекватная (слабая или чрезмерная) фиксация приводит к изменению морфологических свойств ткани и артефициальным результатам иммуногистохимического исследования.

Гистологический материал должен сопровождаться направлением, содержащим информацию о пациенте, дли- тельности и характере заболевания, локализации очага поражения, описании биопсии [10].

Диагностические полостные операщии - торакоскопия/томия, лапароскопия/томия с биопсией внутригрудных, внутрибрюшных лиматических узлов или печени проводятся только при отсутствии увеличенных периферических лиифоузлов и невозможности верификации диагноза.

Гистологические и иммуногистохимические характеристики различных вариантов ЛХ, а также обязательные требования $\kappa$ патологоанатомическому заключению представлены в разделе 7.1. Описание морфологической и иммуногистохимической картины ЛХ представлено в разделе 7.2.

- Пациентам 18-60 лет с верифицированной кЛХ ранней стадии с благоприятным прогнозом, ПЭТ-позитивным (4-5 баллов по шкале Deauville) после 4 циклов ABVD, a также с верифицированной кЛХ ранней стадии с неблагоприятным прогнозом, ПЭТ-позитивным (4-5 баллов по шкале Deauville) после 2 циклов запланированной терапии рекомендуется биопсия ПЭТ-позитивного лимфатического узла либо другого очага поражения [4].

\section{УУР С (УДД 5)}

- Пациентам с кЛХ, за исключением пациентов с кЛХ ІА стадии без признаков поражения костного мозга по данным ПЭТ/КТ рекомендуется получение гистологического препарата костного мозга (трепанобиопсия), патологоанатомическое исследование биопсийного (операционного) материала костного мозга с применением иммуногистохимических методов для уточнения стадии опухолевого процесса [11]

\section{УУР С (УДД 5).}

Комментарии: $y$ пащиентов с кЛX I-II стадии с поражением выше диафрагмы и без очагового поражения костного мозга по результатам ПЭТ/КТ (за исключением пациентов с изменениями в клиническом анализе крови - цитопенией и/или тромбоцитозом) допустимо не выполнять трепанобиопсию, так как вероятность выявить поражение костного мозга в этой группе пачиентов при выполнении трепанобиопсии из подвздошной кости составляет 0,4\%. У пациентов с выявленными на ПЭТ/КТ очаговыми поражениями костей/костного мозга проведение трепанобиопсии необязательно, кроме сомнительных случаев. У пачиентов III-IV стадии, у которых не выполнялась ПЭТ/КТ, выполнение трепанобиопсии является обязательным.

у детей трепанобиопсия подвздошной кости должна обязательно проводиться под общей анестезией.

Всем пащиентам с НЛПлХ, независимо от стадии заболевания, рекомендовано патологоанатомическое исследование биопсииного (операционного) материала костного мозга (трепанобиопсия) и иитологическое исследование отпечатков трепанобиоптата костного мозга.

- Пациентам с ЛХ перед проведением 1-й и последующих линий противоопухолевой терапии рекомендуется в зависимости от сопутствующей патологии осмотр (консультация) врача-кардиолога, врача-эндокринолога, врача-невропатолога, врача-инфекциониста и других врачей-специалистов для определения необходимости терапии сопутствующих заболеваний [12].

УУР С (УДД 5).

\section{3. Лечение}

При выборе тактики и проведении терапии следует учитывать, что у пациента могут быть нестандартные проявления болезни, а также сочетание конкретной болезни с другими патологиями, что может диктовать лечамему врачу изменения в алгоритме выбора оптимальной тактики диагностики и лечения.

Каждый цикл терапии начинается, если состояние паииента удовлетворяет следующим критериял:

- общее удовлетворительное состояние пациента;

- гранулоциты более $1 \times 10^{9} /$;

\section{- тромбоциты более $100 \times 10^{9} / л$}

Для пациентов с иитопенией, обусловленной поражением костного мозга, специфическая терапия возможна и при более низких показателях лейкоцитов и тромбоцитов, однако в этих случаях должна быть обеспечена соответствуюшая сопроводительная терапия.

Рекомендащии по редукиии доз препаратов и увеличению промежутков между циклами терапии представлены в приложении А3.2. 
Пациент прекрашает лечение по протоколу в случаях прогрессии заболевания или токсических эффектов, не позволяюших продолжать ХТ в необходимом оббеме.

ЛТ во всех программах лечения ЛХ должна быть начата в сроки от 2 до 4 нед после окончания XТ, но не позднее 6-йнедели.

\section{1. Первая линия терапии кЛХ, ранние стадии,} у пациентов 18-60 лет

- Ранее не получавшим лечение пациентам 18-60 лет с верифицированной клХ ранней стадии, подтвержденной ПЭТ/КТ, с благоприятным прогнозом, рекомендуется проведение 2-4 циклов полихимиотерапии (ПХТ) по схеме ABVD - доксорубицин ${ }^{* *}$, блеомицин ${ }^{* *}$, винбластин ${ }^{* *}$, дакарбазин** (описание режимов - см. приложение А3.1) с последующей ЛТ в суммарной очаговой дозе (СОД) 30 Гр на зоны исходного поражения в режиме стандартного фракционирования (разовая очаговая доза 2 Гр 5 дней в неделю) $[13,14]$.

УУР А (УДД 2).

Комментарий: $y$ части пациентов можно ограничиться проведением 2-4 ииклов АВVD с последующей ЛТ на зоны исходного поражения СОД 20 Гр на зоны исходного поражения, при условии, что они после тиательно проведенного современного обследования с использованием ПЭТ/КТ строго удовлетворяют следуюшим критериям: исходно не более 2 зон поражения, отсутствие экстранодального поражения, массивных конгломератов (не более 5 см при КТ) и ускоренного СОЭ, негативные результаты промежуточной ПЭТ КТ (ПЭТ-2 1-2 балла по шкале Deauville - cм. приложение Г2) после 2 ииклов ХТ.

Для остальных пациентов этой группы предпочтение следует отдавать 4 ииклам ABVD и, при полном ответе на лекарственную терапию по данным ПЭТ/КТ (1-2 балла по икале Deauville) или КT (остаточные образования менее $2,5 \mathrm{~cm}$ ), рекомендована ЛТ на исходно пораженные лимфатические узлы 20 Гр, а при ответе 3 балла по шкале Dеаиville либо остаточных образованиях более 2,5 см СОД 30 Гр.

- Пациентам 18-60 лет с верифицированной кЛХ ранней стадии с благоприятным прогнозом, у которых после 4 циклов ABVD выявляются опухолевые клетки в биоптате ПЭТ-позитивного резидуального опухолевого лимфоузла, рекомендуется интенсификация терапии - проведение дополнительно двух циклов ХТ по схеме ВЕАСОРР-эскалированный - Этопозид ${ }^{* *}$, доксорубицин ${ }^{* *}$, циклофосфамид**, винкристин ${ }^{* *}$, блеомицин ${ }^{* *}$, прокарбазин ${ }^{* *}$ или дакарбазин ${ }^{* *}$, преднизолон ${ }^{* *}$ (описание режимов - см. приложение А3.1) с последующей ЛТ СОД 30 Гр на зоны исходного поражения в режиме стандартного фракционирования (разовая очаговая доза 2 Гр 5 дней в неделю) [4, 15]. УУР С (УДД 5).

- Ранее не получавшим лечение пациентам 18-60 лет с верифицированной кЛХ ранней стадии, подтвержденной ПЭТ/КТ, и с такими факторами неблагоприятного прогноза, как ускоренное СОЭ и/или поражение 3 и более областей лимфатических коллекторов, рекомендуется проведение 4 циклов ПХТ по схеме ABVD (описание режимов - см. приложение А3.1) с последующей ЛТ в СОД 30 Гр на зоны исходного поражения в режиме стандартного фракционирования (разовая очаговая доза 2 Гр 5 дней в неделю) [16].

УУР А (УДД 1).

- Ранее не получавшим лечение пациентам 18-50 лет с верифицированной I-IIA или IB стадией кЛХ, с подтвержденными КТ или ПЭТ/КТ массивными лимфоузлами средостения и/или Е-стадией и без тяжелых сопутствующих заболеваний рекомендуется проведение 2 циклов BEACOРP-эскалированного + 2 циклов ABVD (описание режимов - см. приложение А3.1) с последующей ЛТ СОД 30 Гр на зоны исходного поражения [17]. УУР А (УДД 2).

- Ранее не получавшим лечение пациентам 18-60 лет с верифицированной только по данным КТ I-IIA или IB стадией кЛХ, но не подтвержденной ПЭТ/КТ, и потому не удовлетворяющим критериям для 4 циклов ABVD, а также пациентам с коморбидностью, которым не может быть проведено 2 цикла ВЕАСОРР-эскалированного + 2 цикла ABVD, рекомендуется проведение 6 циклов ABVD (описание режимов - см. приложение А3.1) с последующей ЛТ СОД 30 Гр на зоны исходного поражения [16].

\section{УУР А (УДД 1).}

- Пациентам 18-60 лет с верифицированной кЛХ ранней стадии с неблагоприятным прогнозом, у которых после 2 циклов запланированной терапии выявляются опухолевые клетки в биоптате ПЭТ-позитивного резидуального опухолевого лимфоузла, рекомендуется интенсификация терапии - проведение дополнительно 2-4 циклов XТ по схеме ВЕАСОРР-эскалированный (описание режимов - см. приложение А3.1) с КТ или ПЭТ/КТ-контролем после каждых 2 циклов и последующей ЛТ СОД 30 Гр на зоны исходного поражения [4, 15].

\section{УУР С (УДД 5$)$.}

- Ранее не получавшим лечение пациентам старше 18 лет с верифицированной I-IIA или IB стадией кЛX с массивными конгломератами лимфоузлов в средостении и/или Естадией, при невозможности проведения исходного и промежуточного ПЭТ/КТ рекомендуется проведение терапии в соответствии с рекомендациями для распространенных стадий [4].

\section{УУР С (УДД 5).}

- Пациентам с верифицированной кЛХ, которым показано проведение ЛТ, рекомендуется, при наличии технической возможности, выполнение облучения с применением протонной терапии для снижения токсичности и риска развития вторичных радиоиндуцированных опухолей [18-20]. УУР С (УДД 4).

\section{2. Первая линия терапии кЛХ, распространенные стадии, у пациентов 18-60 лет}

Стандартом лечения распространенных стадий является ХТ в сочетании с ЛТ на зоны больиих опухолевых массивов, оставиихся после химиотерапевтического воздействия.

В России эта группа пациентов является самой многочисленной и составляет почти 1/2 заболевиих кЛХ. Кроме того, в России до настоящего времени сохраняется больиой дефицит трансплантационных коек, что не позволяет проводить адекватную терапию при рецидивах заболевания. Поэтому главной задачей при лечении этой группы пациентов является достижение максимального числа полных и стойких ремиссий уже на 1-й линии терапии.

- Ранее не получавшим лечение пациентам в возрасте от 18 до 60 лет с распространенными стадиями кЛХ без симптомов интоксикации с МПИ 0-2 при отсутствии абсолютной лимфоцитопении менее $0,6 \times 10^{9} /$ л рекомендуется ПХT по схеме ABVD (описание режимов - см. приложение А3.1) [16].

\section{УУР А (УДД 1).}

Комментарий: количество циклов АBVD зависит от оmвета на лечение (оценка после 2-4 циклов). Рекомендуется суммарно 6 циклов при достижении полной ремиссии (ПР) после 2 и/или 4 ииклов. Назначение 8 ииклов при достижении частичной ремиссии (ЧР) после 4 циклов нежелательно ввиду увеличения кумулятивной дозы доксорубицина ${ }^{* *}$. В последнем случае возможно обсуждение альтернативного продолжения лечения: при достижении ЧР после 4 ииклов $A B V D$ - проведение дополнительно только 2 чиклов $A B V D$ (всего 6 циклов) с последуюшим проведением ЛТ СОД 30 Гр. В случае необходимости возможно подведение дополнительной дозы облучения б Гр нарезидуальные очаги «буст».

- Ранее не получавшим лечение пациентам в возрасте от 18 до 50 лет с распространенными стадиями клХ с симптомами интоксикации и/или с МПИ 3-7 рекомендуется ПХТ по схеме ВЕАСОРР-14 (8 циклов) или ВЕАСОРР-Эскалированный - 6 циклов (описание режимов - см. приложение А3.1) с последующим облучением резидуальных опухолевых масс размером 2,5 см и более СОД 30 Гр с последующим сокращением поля облучения до размеров резидуального очага «буст» и подведением дозы 6 Гр $[16,21]$.

УУР А (УДД 2). 
- Ранее не получавшим лечение пациентам в возрасте от 18 до 50 лет с распространенными стадиями кЛХ с симптомами интоксикации и/или с МПИ 3-7 как альтернатива режимам BЕАСОРР-14 или ВЕАСОРР-эскалированный рекомендуется ПХТ по схеме ЕАСОРР-14 (6 циклов) с последующим облучением резидуальных опухолевых масс размером 2,5 см и более СОД 30 Гр с последующим сокращением поля облучения до размеров резидуального очага «буст» и подведением дозы 6 Гр [22].

УУР С (УДД 4).

Комментарий: если после окончания терапии для оценки эффективности лечения выполнялась ПЭТ/КТ, то при метаболическом ответе 1-3 по шкале Deauville достаточной является СОД 30 Гр, а при ответе 4-5 по шкале Deauville предпочтительно СОД 36 Гр или обсуждение вопроса о 2-й линии терапии. Решение о проведении 2-й линии терапии целесообразно принимать на основании биопсии ПЭТ+ лимфатического узла, так как частота ложноположительных результатов ПЭТ на этом этапе повышена.

Схемы ВЕАСОРР-эскалированный, ВЕАСОРР-14 и ЕАСОРР-14 характеризуются бо́льшей токсичностью, чем схема $A B V D$, и требуют обязательного планового применения колониестимулирующих факторов (гранулоцитарномакрофагальный колониестимулирунощий бактор - Г-КСФ).

С целью уменьшения проявлении синдрома лизиса опухоли у пащиентов с выраженными силптомами интоксикаиии и общим статусом 2 и более по шкале ECOG лечение следует начинать с префазы - одного введения винбластина "** или введения циклофосфамида в* в монорежиме или в сочетании с глюкокортикоидами в течение 1-3 дней (при отсутствии противопоказаний) или одного введения по схеме $A B V D$. После префазы начало плановой терапии по схемам ВЕАСОРР-14, ВЕАСОРР-эскалированный и ЕАСОРР-14 возможно только после прохождения пика снижения лейкоцитов.

- Ранее не получавшим лечение пациентам в возрасте от 50 до 60 лет без тяжелых сопутствующих заболеваний с распространенными стадиями кЛХ с симптомами интоксикации и/или с МПИ 3-7 рекомендуется ПХТ по схеме BEACOРP-14 (8 циклов) или ЕАСОРР-14 - 6 циклов (описание режимов - см. приложение А3.1) с последующим облучением резидуальных опухолевых масс размером 2,5 см и более СОД 30 Гр $[22,23]$.

УУР С (УДД 4).

- У пациентов от 18 до 60 лет с распространенными стадиями кЛХ, получивших интенсивную лекарственную терапию в полном объеме, с резидуальной опухолью 2,5 см и с полным метаболическим ответом по данным ПЭТ-2 и ПЭТ/КТ после окончания терапевтического лечения, рекомендуется рассмотреть вопрос о возможности отказа от ЛТ $[21,24]$.

УУР А (УДД 2).

- У пациентов от 18 до 60 лет с распространенными стадиями кЛХ, выполнивших ПЭТ/КТ до начала лечения, ПЭТ/КТ-позитивных (4-5 баллов по шкале Deauville) после 2 циклов ABVD, рекомендуется интенсификация терапии до ВЕАСОРР-эскалированный (4-6 циклов) или BEACOРP-14 - 6 циклов (описание режимов - см. приложение А3.1) [25]

УУР В (УДД 2).

- Всем пациентам с кЛХ, получающим терапию режимами ВЕАСОРР-эскалированный, ВЕАСОРР-14 или ЕАСОРР-14, рекомендуется плановое назначение Г-КСФ для обеспечения возможности проведения следующего очередного цикла терапии в требуемые сроки и при требуемых показателях крови [22, 26, 27].

\section{УУР В (УДД 3).}

Комментарий: введение Г-КСФ начинается на 9-е сутки (через $1 \mathrm{cym} \mathrm{после} \mathrm{введения} \mathrm{винкристина}{ }^{* *}$ ) независимо от количества лейкоцитов и продолжается до восстановления уровня неитрообилов более $1 \times 10^{9} / л$ и тромбоцитов более $100 \times 10^{9} / л$, но только в том случае, если пик падения уже пройден. Рекомендащии по редукции доз или увеличению промежутков при проведении ХТ в зависимости от показателей крови -см. приложение АЗ.2.
- Пациентам от 18 до 60 лет с кЛХ, завершившим плановую ПХТ, рекомендуется локальная ЛТ с консолидирующей целью в следующих случаях [4, 28, 29]:

- пациентам с исходным поражением костей, в случае сохранения ПЭТ-позитивных резидуальных очагов в костях и отсутствия других проявлений заболевания - локальная ЛТ СОД 36 Гр на остаточные очаги;

- пациентам с исходным поражением позвонка с мягкотканным компонентом и неврологической симптоматикой - до СОД 36 Гр на исходно пораженный позвонок, независимо от результатов лекарственного лечения.

УУР С (УДД 5).

- Пациентам старше 18 лет с кЛХ, подтвержденной иммуногистохимически, которым показано, но невозможно проведение или продолжение интенсивных программ ХТ 1-й линии, или имеющим высокий риск развития пульмонита при применении блеомицина ${ }^{* *}$, в качестве варианта терапии 1-й линии может быть рекомендована комбинация брентуксимаба ведотина** с XT по схеме AVD - режим BV-AVD (описание режимов - см. приложение A3.1) [30].

УУР В (УДД 2).

- Пациентам с кЛХ, получающим в качестве 1-й линии терапии режим BV-AVD, рекомендована первичная профилактика нейтропении Г-КСФ, начиная с 1-го цикла ХТ [30].

УУР В (УДД 2).

Комментарий: профилактику нейтропении следует начинать не позднее 5-го дня после каждого введения хи миопрепаратов по схеме $B V+A V D$, начиная с 1-го введения, независипо от числа лейкоцитов в день введения.

\section{3. Первая линия терапии кЛХ у детей и подростков до 18 лет}

Терапия детей и подростков до 18 лет с верифицированнойЛХ начинается немедленно после верификации диагноза и установления стадии. В случае проведения лапароскопии терапия начинается через 5 дней от операщии.

Параллельно ХТ пащиент может получать гипергидратацию 2,5-3 $\mathrm{л} / \mathrm{m}^{2} /$ сут глюкозо-солевыми растворами.

После проведения каждых 2 ииклов ХТ проводится контрольное обследование [см. Раздел 2. Диагностика заболевания или состояния (группы заболеваний или состояний), медищинские показания и противопоказания к применению методов диагностики] - через 10-14 дней от окончания цикла.

- Ранее не получавшим лечение пациентам в возрасте до 18 лет с IA/B или IIA стадиями ЛХ рекомендуется ПХТ по схеме OЕРА - 2 цикла (описание режимов - см. приложение А3.1) [31].

УУР В (УДД 3).

- Пациентам в возрасте до 18 лет с IA/В или IIA стадией ЛX, достигшим полного метаболического ответа (подтвержденного ПЭТ/КТ) после 2 циклов ОЕРА рекомендуется проведение 1 цикла по схеме COPDAC (описание режимов - см. приложение А3.1) с последующим отказом От ЛТ [32].

УУР С (УДД 5).

- Ранее не получавшим лечение пациентам в возрасте до 18 лет с IEA/B, IIEA, IIB или IIIA стадией ЛХ рекомендуется ПХТ по схеме ОЕРА (2 цикла) + COPDAC - 2 цикла (описание режимов - см. приложение А3.1) [31].

УУР В (УДД 3).

- Ранее не получавшим лечение пациентам в возрасте до 18 лет с IIEB, IIIEA/B, IIIB, IVA/В стадией ЛХ рекомендуется ПХТ по схеме ОЕРА (2 цикла) + COPDAC - 4 цикла (описание режимов - см. приложение А3.1) [31]

УУР В (УДД 3).

- Пациентам в возрасте до 18 лет с ЛХ с ПЭТ/КТ-позитивной опухолью после 2-го блока ПХТ рекомендуется ЛТ на первично пораженные области СОД 19,8 Гр [33].

\section{УУР С (УДД 5)}

Комментарий: при наличии показаний к проведению ЛТ у пациентов с ЛХ необходимо облучить все пораженные лимфоузлы, выявленные при инициальном, выполненном до начала ХТ, ПЭТ-исследовании. При формировании объемов облучения необходимо следовать ICRU 50/62 [34]. 
Минимальные требования к проведению облучения у детей - 3D-конформная ЛТ. ЛТ должна проводиться на линейном ускорителе фотонами с энергией не менее $6 \mathrm{MV}$, оснащенном многолепестковым коллиматором и системой контроля положения пациента и/или мишени (КТ в коническом пучке, система портальной визуализации и др.). Не исключается использование электронных пучков с подходящей энергией для облучения поверхностно расположенных групп лимфбатических узлов, например, паховых. Возможно применение лТ с модуляцией интенсивности (IMRT), объемно-модулированной ЛТ (VMAT), TотоTherapy, протонотерапии.

ЛТ опухолей у детей должна проводиться с применением механической имлобилизачии (индивидуальная маска из термопластического материала, вакуумный матраи). Необходимо предусмотреть возможность облучения под общей анестезией пациентов в возрасте до 4 лет и по показаниям в более старием возрасте.

Все области поражения предпочтительно облучать одновременно. При III-IV стадиях решение о последовательном облучении принимается индивидуально, при этом, в первую очередь, в объем ЛТ включаются остаточные опухолевые массы либо зоны с исходным обширным поражением. Перерыв между этапами лТ должен быть не более 2 нед.

В макроскопический объем опухоли (GTV) входит обвем пораженных лимбоузлов. Клинический обтем мишени (CTV) включает в себя GTV с безопасным краем 1-2 см с учетом анатомических баръеров для распространения болезни (обычно в анатомических границах региона). Планируемый объем мишени (РTV $)$ включает в себя СТV плюс принятый в данном учреждении отступ, обычно 7-10 мм во всех направлениях. Для средостения, парааортальной зоны и области таза отступ CTV в краниокаудальном направлении должен составлять не менее 2 см. Лимфоузлы корней легких рассматриваются как самостоятельный регион.

СОД облучения составляет 19,8 Гр, при стандартном фракиионировании с РОД 1,8 Гр за фракцию, 5 фракций в неделю. Все поля облучаются ежедневно. Допустимо снижение РОД до 1,5-1,6 Гр при больших объемах облучения и/или у детей младиего возраста.

Гранииа планируемого лучевого воздействия определяется размерами опухоли по окончании ХТ с дополнительным захватом 1-2 см.

ЛТ должна быть начата на 2-4-й неделе после завериения ХТ, т.е. на 14-28-й день от приема последней дозы преднизолона.

- Пациентам в возрасте до 18 лет с ЛХ, с остаточной опухолью более $100 \mathrm{~cm}^{3}$, а также пациентам с остаточной опухолью более $5 \mathrm{~cm}^{3}$ и регрессией опухоли 75\% от исходного объема рекомендуется дополнительное облучение СОД 10 Гр (РОД 2 Гр) [33].

\section{УУР С (УДД 5)}

Комментарий: оббем буста $\left(P T V_{\text {буст }}\right)$ определяется размером остаточной опухоли с безопасным краем по $1 \mathrm{~cm}$ плюс принятыи в данном учреждении отступ на PTV (PTV буст определяется по аналогичному алгоритму определения РTV). При этом границы объема РTV буст не должны выходить за гранииы РTV.

- Пациентам в возрасте до 18 лет с экстранодальным поражением ЛХ рекомендуется проведение ЛТ в зависимости от пораженного органа [29]:

- Селезенка: орган считается пораженным при наличии очагового накопления РФП при инициальном ПЭТ/КТ. При этом необходимо проведение облучения всей селезенки с учетом возможных смещений органа до СОД 19,8 Гр. Диффузное накопление РФП в селезенке не всегда считается поражением и должно обсуждаться индивидуально.

- Легкие: показанием к облучению легкого является сохранение в нем остаточных очагов после 2 курсов ХТ, выявленных на первичном ПЭТ/КТ. При наличии солитарного поражения органа после 2 курсов ПХТ очаг облучается локально с РОД 1,8 Гр, СОД 19,8 Гр. Отступ на СТV - 1 см, плюс дополнительный отступ на PTV. При наличии 2 и более очагов орган облучается тотально до СОД 12-15 Гр, РОД $1-1,2$ Гр.
- Печень: показанием к облучению печени является ее инициальное поражение. При наличии солитарного очага поражения в печени необходимо проведение локальной ЛТ СОД 19,8 Гр. При этом необходимо учесть безопасный край 1-2 см и отступ РTV. В случае выявления 2 или более очагов необходимо проведение тотального облучения печени с учетом возможных смещений органа до СОД 15 Гр с РОД $1-1,2$ Гр.

- Почки: показанием к облучению почки является ее инициальное поражение, также регистрируемое после 2 курсов ПХТ. Орган облучается тотально с учетом возможных смещений органа до СОД 12 Гр с РОД 1-1,2 Гр.

- Кости: показанием к облучению костей скелета является их инициальное поражение. При выявлении у пациента 1-2 очагов поражения костей необходимо их облучение с безопасным краем 1-2 см и с учетом погрешности смещения до СОД 19,8 Гр с РОД 1,8 Гр. В случае выявления более 2 очагов костного поражения необходимость их облучения обсуждается индивидуально.

\section{УУР С (УДД 5)}

- Ранее не получавшим лечение пациентам в возрасте до 18 лет с ЛХ с компрессией трахеи и синдромом сдавления нижней полой вены при наличии рисков анестезии оперативное вмешательство должно проводиться с последующей продленной интубацией, при отсутствии такой возможности рекомендуется предфаза преднизолоном $^{* *}$ 30-60 мг/м² в течение 3-5 дней до проведения манипуляций под общей анестезией [35].

\section{УУР С (УдД 5).}

\section{4. Первая линия терапии кЛХ у пациентов старше 60 лет}

- Ранее не получавшим лечение пациентам старше 60 лет с распространенными стадиями кЛХ рекомендуется индивидуальный выбор программы лечения в зависимости от сопутствующих заболеваний пациента [4, 36, 37].

\section{УУР С (УДД 5).}

Комментарий: относительная редкость участия лии старие 60 лет в клинических исследованиях (менее 10\%) создает сложности в доказательстве эффективности тех или иных програмл лечения $u$, соответственно, в выборе терапии 1 -й линии для этих пациентов. Плохая переносимость относительной дозоинтенсивности лечения, приближенной к адекватной расчетной величине, приводит к снижению относительной дозоинтенсивности до 65\% от запланированной и к существенному укорочению как общей выживаемости, так и выживаемости до прогрессирования.

Приемлемая по гематологической токсичности и әбфективности програмиа ABVD - «золотой стандарт» представляет высокий риск развития легочной токсичности, възванной блеомииином **, частота которой в группе 60 лет составляет 24\%, а связанная с ней смертность 18\%. Применение интенсивных програмл в этой возрастной группе сопряжено с высоким риском смертности, ассоииированной с терапией: при использовании програмль ВЕАСОРР в базовых дозах смертность, связанная с терапией, достигает 21\%, но исключение этопозида ${ }^{* *}$ - программа ВАСОРР - снижает данный показатель до $12 \%$, что все же является неприемлемьм риском для пациентов с ЛХ. В 2 проспективных исследованиях, показавиих әффективность режима VЕРЕМВ, смертность от токсичности терапии составляла 3 и $7 \%$.

Имеюоиася сердечная патология и/или риск развития кардиальных осложнении требуют проведения програми без препаратов из группы антрациклинов, например, ChIVPP, СVPP, СОРP. Следует учитывать, что терапевтиче ский потенциал схем СОРP/CVPP реализуется в полной мере лишь при условии получения пациентом не менее 95\% дозы каждого из препаратов. Также следует минимизировать объем ЛТ на область средостения. В случае сочетания кардиальной и легочной патологии возможно применение идарубииин:*\#_содержашей програмиы IVDG, в которой отсутствует блеомицин **, а режим введения препаратов предполагает возможность оптимального контроля миелотоксичности [38]. 
Сцелью снижения риска кардиотоксических осложнений доксорубицина **: возможна замена последнего на менее кардиотоксичные - митоксантрон ${ }^{* *}$ или идарубицинн"\# (из расчета: доксорубицин ${ }^{* *} 50$ мг/ $\mathrm{s}^{2}-$ митоксантрон $^{* *}$

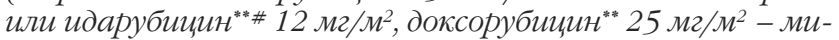
токсантрон *** или идарубицин ${ }^{* *} 5 \mathrm{mz} / \mathrm{s}^{2}$ ) [38].

Кроме того, с целью минимизации риска миелотоксических осложнений или при коморбидной отягощенности возможно применение програми СНОР-21, СVР. В крайних случаях пациентам, имеюоим серьезные противопоказания к назначению ПХТ, можно назначать метрономную терапию типа РЕРС или монотерапию агентами, активными против ЛХ. Кратность назначения и длительность курса в данном случае будут зависеть от әффективности и токсических осложнений. Применяются винбластин ${ }^{* *}$ по 10 мг внутривенно 1 раз в 10 дней, этопозид ${ }^{* *}$ по $50 \mathrm{mz} / \mathrm{s}^{2}$ или ииклофосфамид** по 50-150 мг перорально, курсами по 7-14 дней.

\section{5. Выбор терапии 2-й и последующих линий у пациентов с кЛХ}

- Пациентам от 18 до 60 лет с кЛХ из группы низкого риска (ранние стадии ЛХ без неблагоприятных прогностических признаков), получившим в качестве 1-й линии терапии только 2 цикла по схеме ABVD с последующим облучением зон исходного поражения, при рецидиве заболевания рекомендуется рассмотреть возможность проведения 6 циклов по схеме ВЕАСОРР-эскалированный (описание режимов - см. приложение А3.1) [4].

УУР С (УДД 5).

- Пациентам до 50 лет с кЛХ с хорошим соматическим статусом (ECOG 0-1, отсутствие тяжелых сопутствующих заболеваний) c рефрактерным течением заболевания (не достигнута ЧР после окончания химиотерапевтического этапа, констатировано прогрессирование), либо с первым ранним рецидивом (продолжительность ремиссии менее 1 года после завершения индукционного лечения), либо в первом позднем рецидиве с большой массой опухоли или во втором позднем рецидиве, если на предшествующих этапах лечения не проводилось облучение поясничного отдела позвоночника и костей таза, и/или не использовались циклы, включающие такие алкилирующие препараты, как мелфалан"*\# и ломустин ${ }^{* *}$, рекомендуется проведение консультации в трансплантологическом центре для решения вопроса о возможности аутологичной трансплантации гемопоэтических стволовых клеток (аутоТГСК), и, при возможности ее выполнения, планирование режимов и сроков противорецидивной терапии [4, 39].

\section{УУР С (УДД 5).}

- Пациентам до 50 лет с рефрактерным течением заболевания (не достигнута ЧР после окончания химиотерапевтического этапа, констатировано прогрессирование), либо с первым ранним рецидивом (продолжительность ремиссии менее 1 года после завершения индукционного лечения), либо в первом позднем рецидиве с большой массой опухоли или во втором позднем рецидиве, не получавшим в первом рецидиве высокодозной ХТ (ВДХТ) с аутоТГСК, если на предшествующих этапах лечения не проводилось облучение поясничного отдела позвоночника, костей таза, и/или не использовались циклы, включающие такие алкилирующие препараты, как мелфалан**\# и ломустин ${ }^{* *}$, которым планируется аутоТГСК, рекомендуется проведение ХТ по любой из схем терапии 2-й линии на выбор лечащего врача для определения химиочувствительности опухолевых клеток, уменьшения опухолевой массы и мобилизации стволовых клеток перед этапом ВДХТ [39, 40].

УУР С (УДД 5$)$.

Комментарий: в качестве терапии 2-й линии могут применяться комбинации ICE, DHAP, IGEV, GDP, ESHAP, GemОx, IЕР и др. (описание режимов - см. приложение А3.1). Все эти режимы илеют сопоставимую әбфективность и токсичность и могут применяться в зависимости от опыта и предпочтенийлечамего врача.
- Пациентам до 50 лет с рефрактерным течением заболевания (не достигнута ЧР после окончания химиотерапевтического этапа, констатировано прогрессирование), либо с первым ранним рецидивом (продолжительность ремиссии менее 1 года после завершения индукционного лечения), либо в первом позднем рецидиве с большой массой опухоли или во втором позднем рецидиве, если на предшествующих этапах лечения не проводилось облучение поясничного отдела позвоночника и костей таза и/или не использовались циклы, включающие такие алкилирующие препараты, как ${ }^{*}$ мелфалан ${ }^{* *}$ и ломустин ${ }^{* *}$, которым планируется аутоТГСК и начата ХТ рецидива, рекомендуется проведение стимуляции гемопоэза с мобилизацией и последующим сбором гемопоэтических стволовых клеток (ГСК) для последующего проведения аутоТГСК [41] УУР С (УДД 5).

Комментарий: сроки и режим мобилизации ГСК должны выполняться в соответствии с рекомендациями трансплантационного центра, в котором планируется аутоТГСК

- Пациентам до 50 лет с рефрактерным течением заболевания (не достигнута ЧР после окончания химиотерапевтического этапа, констатировано прогрессирование), либо с первым ранним рецидивом (продолжительность ремиссии менее 1 года после завершения индукционного лечения), либо в первом позднем рецидиве с большой массой опухоли или во втором позднем рецидиве, если на предшествующих этапах лечения не проводилось облучение поясничного отдела позвоночника, костей таза и грудины и/или не использовались циклы, включающие такие алкилирующие препараты, как мелфалан"** и ломустин ${ }^{* *}$, которым запланирована аутоТГСК и у которых достигнута полная ПЭТ-негативная ремиссия после ХТ рецидива, рекомендуется проведение высокодозной терапии одним из режимов кондиционирования (описание режимов - см. приложение А3.1) с последующей трансплантацией ГСК [39, 40].

\section{УУР С (УДД 5).}

- Пациентам до 50 лет с рефрактерным течением заболевания (не достигнута ЧР после окончания химиотерапевтического этапа, констатировано прогрессирование), либо с первым ранним рецидивом (продолжительность ремиссии менее 1 года после завершения индукционного лечения), либо в первом позднем рецидиве с большой массой опухоли или во втором позднем рецидиве, если на предшествующих этапах лечения не проводилось облучение поясничного отдела позвоночника и костей таза и/или не использовались циклы, включающие такие алкилирующие препараты, как мелфалан"*\# и ломустин ${ }^{* *}$, которым запланирована аутоТГСК и у которых не достигнута полная ПЭТ-негативная ремиссия после ХТ рецидива, рекомендуется проведение альтернативной терапии рецидива для достижения полной ПЭТ-негативной ремиссии перед высокодозной терапией с последующей трансплантацией ГСК [42]

\section{УУР С (УДД 4).}

- Пациентам с иммуногистохимически доказанной кЛХ которым выполнена аутоТГСК, имеющим повышенный риск рецидива или прогрессирования заболевания (резистентность к 1-й линии терапии, рецидив или прогрессирование лимфомы в течение 12 мес после окончания 1-й линии терапии, наличие экстранодального поражения при рецидиве до аутоТГСК), после восстановления от аутоТГСК рекомендуется проведение консолидирующей терапии брентуксимабом ведотином** $^{*}$ целью воздействия на минимальную остаточную болезнь [43].

УУР А (УДД 2).

Комментарий: консолидируюиую терапию рекомендовано проводить в объеме 16 циклов (введении), с контрольным обследованием каждые 4 введения.

Пачиентам с кЛХ до 18 лет терапия брентуксимабом ведотином ${ }^{* *}$ проводится после аутоТГСК только в тех случаях, когда до трансплантации не была достигнута метаболическая ремиссия. 
- Пациентам с рецидивами или рефрактерным течением кЛХ, которым не планируется аутоТГСК, рекомендуется проведение ХT рецидива по любой из схем терапии 2-й линии на выбор лечащего врача [39, 40].

\section{УУР С (УДД 5).}

Комментарий: 8 качестве терапии 2-й линии могут применяться комбинации ICE, DHAP, IGEV, GDP, ESHAP, GemOx, IEP и др. (описание режимов - см. приложение АЗ.1). Все эти режимы илеют сопоставимую эффективность и токсичность и могут применяться в зависимости от опьта и предпочтений лечамего врача.

- Пациентам с кЛХ с рецидивом или рефрактерностью после аутоТГСК, а также не-кандидатам на аутоТГСК, рецидивировавшим после 2 или более линий предшествующей терапии, рекомендуется проведение терапии брентуксимабом ведотином** в монорежиме (описание режима - см. приложение А3.1) [44]

\section{УУР В (УДД 3).}

Комментарий: при подтверждении чувствительности опухоли проводится как минимум 8, но не более 16 ииклов (введений) терапии с осуществлением контроля в процессе лечения каждые 4 иикла. После окончания лечения контроль осуществляется в стандартном режиме.

- Пациентам с кЛХ старше 18 лет с рецидивом или рефрактерностью после аутоТГСК и брентуксимаба ведотина** либо после 3 и более линий системной терапии, включающей аутоТГСК, в качестве одной из возможных опций рекомендуется проведение терапии ниволумабом** (описание режима - см. приложение А3.1) [45]

УУР А (УДД 3).

Комментарий: лечение препаратом проводится до прогрессирования или непереносимой токсичности. Показания для отиены препарата обсуждаются отдельно в каждой клинической ситуации по результатам обследования каждые 6 мес.

- Пациентам с кЛХ с рецидивом или рефрактерностью после 3 и более линий системной терапии в качестве одной из возможных опций рекомендуется проведение терапии пембролизумабом** (описание режима - см. приложение А3.1) [46].

\section{УУР В (УДД 3).}

Комментарий: лечение препаратом проводится до прогрессирования или непереносимой токсичности. Показания для отмены препарата обсуждаются отдельно в каждой клинической ситуации по результатам обследования каждые 6 мес.

- Пациентам с кЛХ с рецидивом или рефрактерностью после ауто'ТСК, брентуксимаба ведотина** и ингибиторов иммунных контрольных точек (ниволумаб**, пембролизумаб $^{* *}$ и др.) рекомендуется консультация в трансплантологическом центре для решения вопроса о целесообразности и возможности проведения трансплантации аллогенных ГСК крови $[47,48]$. УУР В (УДД 2).

- Пациентам с ЛХ, исчерпавшим возможности трансплантации, таргетной терапии и иммунотерапии, может быть рекомендовано рассмотреть вопрос о проведении низкотоксичной цитостатической терапии или ЛТ по усмотрению лечащего врача с паллиативной целью [4].

УУР С (УДД 5).

Комментарий: с паллиативной целью возможно использование гемиитабин ** - (для пациентов старие 18 лет), или ломустинсодержаших ${ }^{* *}$ режимов, бендамустина $^{* *}$ в монорежиме, и/или локальной лТ, что позволяет у части пациентов получить достаточно длительные ремиссии, удовлетворительное качество жизни и хорошие показатели длительной выживаемости. выбор терапии для этих пациентов всегда индивидуален. У пациентов с иитопенией с паллиативной иелью возможно использование различных метрономных режимов на фоне сопроводительной терапии. Такой подход позволяет у части пациентов достичь удовлетворительного качества жизни даже без достижения ремиссии.

\section{6. Лечение НЛпЛХ}

Вторым типом ЛХ в пересмотренной классификаиии опухолей гемопоэтической и лимфоидной тканей ВОЗ 2017 2. является НЛПЛХ. НЛПлХ - это самостоятельная редкая (заболеваемость - 1,5 на 1 млн) индолентная лимбола с иным, чем у кЛХ, патогенезом и иммунофенотипом. НЛПЛХ отличается от кЛХ и клеточным составом (лимфоцитарно-гистиоцитарные клетки), и иммунофенотипом, и клиническим поведением, и, соответственно, подходом к терапии. Заболевание чаще диагностируется у мужчин в возрасте 20-40 лет и неплохо поддается лечению. Прогноз нодулярной лимфомы благоприятный, однако у 3-5\% пациентов отмечается ее трансформация в крупноклеточную В-клеточную лимфому, богатую Т-лимфоиитами. Лечение в ранних стадиях может проводиться даже без применения химиопрепаратов, но с ЛТ +/-ритуксимаб ${ }^{* *}$. В случае речидива крайне необходима повторная биопсия, так как есть вероятность трансформации нлПлХ в диффузную В-клеточную крупноклеточную неходжкинскую лимбому, богатую Т-лимфочитами.

- Ранее не получавшим лечение пациентам 18 лет и старше с НЛПЛХ I-IIA стадии без массивного опухолевого поражения рекомендовано проведение ЛТ СОД 30 Гр и/или монотерапии ритуксимабом** в режиме для ранних стадий В-клеточных неходжкинских лимфом [49-51].

УУР С (УдД 4)

- Ранее не получавшим лечение пациентам моложе 18 лет с НЛПЛХ I-IIА стадии без массивного опухолевого поражения рекомендовано хирургическое удаление очага и динамическое наблюдение [52, 53].

УУР В (УДД 3).

- Ранее не получавшим лечение пациентам 18 лет и старше с НЛПЛX I-II стадии с массивным опухолевым поражением и/или с симптомами интоксикации (В-симптомами) рекомендовано проведение XТ по схеме ABVD в комбинации с ритуксимабом**\# и ЛТ СОД 30 Гр [54]

\section{УУР С (УДД 5).}

Комментарий: ЛТ пациентал с НЛПЛХ проводится на зоны исходно пораженных лимфатических узлов, определяемых по данным ПЭТ/КТ, с отступами 2-5 см. При невозможности выполнения ПЭТ/КТ до начала лечения объем ЛТ определяется по данным исходных ультразыукового исследования (УЗИ), КТ.

- Ранее не получавшим лечение пациентам моложе 18 лет с НЛПЛX I-II стадии с массивным опухолевым поражением и/или с симптомами интоксикации (В-симптомами) рекомендовано проведение XT по схеме CVP с ритуксимабом**\# [55].

УУР С (УДД 5$)$.

- Ранее не получавшим лечение пациентам с распространенными (III-IV) стадиями НЛПЛХ рекомендовано применение режима R-CHOP (описание режимов см. приложение А3.1) [56].

УУР С (УДД 5).

- Пациентам с рецидивами или рефрактерным течением НЛПЛХ без признаков трансформации в диффузную В-клеточную крупноклеточную лимфому рекомендована терапия рецидивов по схемам ХT, аналогичным схемам для лечения рецидивов кЛХ, с добавлением ритуксимаба ${ }^{* * *}[57]$.

\section{УУР С (УДд 5).}

- Пациентам с повторными рецидивами НЛПЛХ без признаков трансформации в диффузную В-клеточную крупноклеточную лимфому рекомендуется проведение консультации в трансплантологическом центре для решения вопроса о возможности аутоТГСК $[58,59]$.

\section{УУР С (УДД 5)}

\section{7. ЛХ и беременность}

- Пациенткам с активным течением ЛХ, у которых определяется беременность, или при выявлении ЛХ во время беременности рекомендовано проведение консилиума, включающего гематолога и акушера-гинеколога, для индивидуального выбора тактики ведения пациент- 
ки $[7,60]$. Диагноз ЛХ обязательно должен быть верифицирован морфологически, для определения степени распространенности процесса предпочтение отдается ультразвуковой диагностике и магнитно-резонансной томографии (MPT) $[7,60]$

УУР С (УДД 5).

Комментарий: при любых формах, степени агрессивности и стадиях ЛХ возможны три варианта тактики ведения: прерывание беременности, выжидательная тактика или начало противоопухолевой терапии. Выбор тактики должен базироваться на следующих приниипах:

1. Сочетание беременности с ЛХ в ремиссии не служит показанием к прерыванию беременности.

2. При выявлении ЛХ во II или III триместрах возможно, если это необходимо, проведение ПХТ во время беременности. Желательно, если это возможно, избегать схем ПХТ, содержащих алкилирующие препараты. При проведении ПХТ необходимо назначение низкомолекулярного гепарина с целью профилактики венозных тромбоэлболических осложнений.

3.При выявлении ЛХ в І триместре беременности уженшин с благоприятным и промежуточным прогнозом (пачиенты с IA и ІІА стадией без факторов риска - массивного поражения средостения и поражения более 4 областей лимфатических коллекторов) возиожны выжидательная тактика и начало лечения во II или III трилестре беременности.

4. При реиидивирующем течении ЛХ, а также всем женщинам с впервые диагностированной лимфомой с неблагоприятным прогнозом заболевания, выявленной в I триместре, показано прерывание беременности.

5. Во всех случаях возможность сохранения беременности при активном течении ЛХ, сроки начала лечения, а также вопросы выбора схем лечения во время беременности решает только врач-гематолог или врач-онколог. В такой ситуации всегда необходимо стремиться организовать родоразрешение в перинатальных центрах или роддомах с наличием детской реанимачии.

6. Время родоразрешения должно быть определено совместно врачами-акушерами и врачами-онкологами или врачами-гематологами. Когда это необходимо, плод должен быть извлечен в срок наибольшей безопасности для его здоровъя (после 33-34 нед беременности) и здоровъя матери. В связи с возможной миелосупрессией как у матери, так и у плода, ПХТ должна быть отменена за 3 нед до предполагаемого срока родоразрешения. Наиболее благоприятным и безопасным методом родоразрешения на фоне ПХТ являются роды через естественные родовые пути. Оперативное родоразрешение должно проводиться по акушерским показаниям.

- Беременным пациенткам с ЛХ с симптомами интоксикации, синдромом сдавления верхней полой вены или угрозой прогрессирования ЛХ рекомендовано начать про-

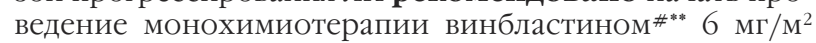
каждые 2-4 нед для стабилизации болезни и до родоразрешения $[7,60]$.

УУР С (УДД 5).

Комментарий: $y$ пациенток с силптомами ЛХ, резистентных к монохимиотерапии винбластином ${ }^{\# * *}$, схемой выбора является схема ABVD [61]. После родоразрешения проводят полное обследование и адекватный для конкретной ситуачии объем лечения, учитываюший уже полученную терапию.

- Беременным пациенткам с ЛХ рекомендовано проведение профилактики тромбоэмболических осложнений в течение беременности и в послеродовом периоде (6 нед после родов) [7]

УУР С (УДД 5).

Комментарий: тромбопрофилактика должна подбираться индивидуально на основании профильных рекомендащий.

\section{8. Оценка ответа на лечение}

Всем пациентам с ЛХ, после 2 и 4 циклов ХТ, после окончания химиотерапевтического этапа и после завершения всей программы лечения, рекомендуется оценка ответа на терапию в соответствии со стандартными критериями ответа на лечение лимфом для определения дальнейшей тактики ведения пациента (см. раздел 6.4) [1, 4, 62]. УУР С (УДД 5).

\section{9. Сопутствующая и сопроводительная терапия}

- Всем пациентам с ЛХ с исходно массивным поражением, получающим противоопухолевую терапию, рекомендовано проведение профилактики синдрома лизиса опухолей согласно существующим профильным рекомендациям [63]. УУР С (УДД 5).

- Всем пациентам с ЛХ со сниженной концентрацией гемоглобина крови рекомендовано лечение анемии согласно существующим профильным рекомендациям [64, 65]. УУР С (УДД 5).

- Всем пациентам с ЛХ, получающим противоопухолевую ХТ или ЛТ, рекомендованы профилактика и лечение тошноты и рвоты в зависимости от эметогенного потенциала проводимого лечения согласно существующим профильным рекомендациям [66].

УУР С (УДД 5).

- Пациентам с ЛХ с выявленной симптоматической гипогаммаглобулинемией (перенесенная тяжелая инфекция, $\operatorname{Ig} G<4$ г/л) рекомендовано проведение заместительной терапии Ig\# человека нормальным 0,2-0,4 г/кг внутривенно каждые 3-4 нед в течение 12 мес [67, 68].

УУР С (УДД 5).

Комментарий: терапия проводится под контролем уровна IgG каждые 6 мес, пересмотр дозы Ig\# человека нормального каждые 6 мес. После завершения терапии проводитса пожизненное мониторирование уровна IgG 1 раз в год, в случае повторного снижения $\operatorname{Ig} G<4$ г/л проводятся повторные курсы заместительной терапии аналогичным препаратом в аналогичном режиме в течение 12 мес.

- Для пациентов с ЛХ детородного возраста рекомендуется проведение консультации о риске бесплодия после терапии и о потенциальных методах сохранения фертильности (криоконсервация спермы у мужчин, овариальная супрессия у женщин) [69].

УУР С (УДД 5).

- Для пациенток с ЛХ - девочек и молодых женщин, у которых планируется ЛТ на подвздошную область, рекомендуется рассмотрение вопроса о необходимости лапароскопической транспозиции яичников для их защиты [70]. УУР С (УДД 5).

Комментарий: транспозиция яичников особенно показана, если ожидаемая доза облучения на яичники составит более 5 Гр, так как при этом может возникнуть длительная дисфункиия яичника. Этого можно избежать, если Лт проводится с противоположных полей в СОД 20 Гр и яичник находится, как минимум, на расстоянии 2 см от границылучевой области.

При проведении овариопексии нить должна быть обязательно помечена клипсой. Процедура выполняется хирургом немедленно после консультащии лучевого терапевта до начала ЛТ на поддиафрагмальную область.

\section{Обезболивание}

- Пациентам с ЛХ при возникновении острого или хронического болевого синдрома рекомендуется провести диагностику причины болевого синдрома и последующую патогенетическую или симптоматическую терапию болевого синдрома в соответствии с существующими профильными рекомендациями $[71,72]$.

УУР С (УДД 5).

Диетотерапия - не применяется. 
https://doi.org/10.26442/18151434.2020.2.200169

\section{4. Реабилитация}

- Всем пациентам с ЛХ на всех этапах терапии заболевания, а также после завершения лекарственного лечения рекомендуется комплексная реабилитация, а также, при необходимости, поддерживающая терапия [73].

УУР С (УДД 5).

Комментарий: специальных методов реабилитации при ЛХ не существует. Реабилитация пациентов с ЛХ должна носить комплексный характер, охватывая не только медицинкие, но и социально-психологические аспекты адаптащии пациента к нормальной жизни. Такая реабилитация требует, кроме медицинской помочи, обязательного участия сочиальных работников и психологов. Програмиы реабилитации разрабатываются индивиду ально, в зависимости от выявленных осложнений лекарственного лечения, сопутствующей патологии, социальных и психологических проблем.

Реабилитация при возникновении осложнений в течение заболевания и лечения проводится в ралках соответствуюицх нозологий.

\section{https://doi.org/10.26442/18151434.2020.2.200170}

\section{5. Профилактика}

Методов профилактики ЛХ в настоящее время не существует, поскольку неизвестны этиологические факторы, ведуиие кразвитию заболевания.

- Всем пациентам с ЛХ на протяжении всей жизни пациента - как в период лечения, так и вне лечения - рекомендуется соблюдать предписания врача-гематолога по лечению, избегать провоцирующих заболевание факторов, изменить виды и условия труда на невредные и облегченные, ограничить инсоляции и физиотерапевтические методы лечения, женщинам детородного возраста в ПР заболевания - придерживаться тактики планирования беременности [4].

УУР С (УДД 5).

- Взрослым пациентам, завершившим лечение по поводу ЛХ с достижением ПР, рекомендуется диспансерное наблюдение у врача-онколога или врача-гематолога в течение первого года после завершения терапии каждые 3 мес, 2-го года - каждые 6 мес, в дальнейшем - ежегодно, после 5 лет - каждые 2 года $[1,4]$

УУР С (УДД 5).

Комментарий: диспансерное наблюдение должно включать тиательный сбор жалоб, клинический осмотр пащиента, рентгенологический контроль органов грудной клетки, УЗИ брюшной полости и периферических лимфа-

тических коллекторов. Для пачиентов, получавших антрациклины и блеомицин в в сочетании с облучением средостения, - исследование функии сердиа и легких.

- Детям и подросткам, завершившим лечение по поводу ЛХ с достижением ПР, рекомендуется диспансерное наблюдение у врача-онколога или врача-гематолога по графику, представленному в табл. 5.1 [35].

\section{УУР С (УДД 5).}

Комментарий: $\mathrm{cm}$. табл. 5.1.

- Всем пациентам, достигшим ПР после лечения по поводу ЛХ, включавшего ЛТ на область шейно-надключичных лимфатических коллекторов, рекомендуется ежегодно в течение 5 лет исследование функции щитовидной железы (уровень тиреостимулирующего гормона) и при необходимости - консультация врача-эндокринолога $[1,4]$. УУР С (УДД 5).

- Детям и подросткам, завершившим лечение по поводу ЛХ с достижением ПР, рекомендуется скрининг поздних эффектов терапии (табл. 5.2), скрининг органных осложнений проведенного лечения (табл. 5.3) и скрининг по кардиотоксическим эффектам (в зависимости от проведенного лечения и возраста пациента - табл. 5.4) [35]

УУР С (УДД 5).

Комментарий: см. табл. 5.2, 5.3, 5.4

\begin{tabular}{|c|c|c|c|c|c|c|}
\hline Обследование & 1-й год & 2-й год & 3-й год & 4-й год & 5-й год & 6-й год \\
\hline Клинический осмотр & $4-8 x$ & $4-8 x$ & $4 x$ & $2 x$ & $2 x$ & \multirow{7}{*}{ Индивидуально } \\
\hline OAK & $4 x$ & $4 x$ & $2 x$ & $2 x$ & $2 x$ & \\
\hline ФВД & $1 x$ & \multicolumn{4}{|c|}{ Индивидуально } & \\
\hline Узи & $4 x$ & $4 x$ & $2 x$ & $2 x$ & $2 x$ & \\
\hline $\mathrm{KT}, \mathrm{MPT}$ & $2 x$ & $2-1 x$ & $1 \mathrm{x}$ & $1 \mathrm{x}$ & $1 \mathrm{x}$ & \\
\hline Гормоны щитовидной железы & $1 x$ & $1 x$ & $1 x$ & $1 x$ & $1 x$ & \\
\hline ЭКГ, ЭхоКГ & & $1 \mathrm{x}$ & & & $1 \mathrm{x}$ & \\
\hline
\end{tabular}

Таблица 5.2. Скрининг поздних эффектов противолимфомной терапии Table 5.2. The screening of late effects of lymphoma therapy

\begin{tabular}{|c|c|}
\hline $\begin{array}{l}\text { 1-й год от окончания терапии } \\
\text { (каждые } 3 \text { мес) }\end{array}$ & $\begin{array}{l}\text { - Осмотр (рост/вес, объем яичек, признаки полового созревания) } \\
\text { • Ежемесячное самообследование молочных желез } \\
\text { - ОАК+СОЭ } \\
\text { • Рентгенография органов грудной клетки/КТ шеи/грудной клетки для I-II + КТ живота/таза для III-IV стадии } \\
\text { - ЭКГ/ЭхоКГ/Холтер, лютеинизирующий гормон, фолликулостимулирующий гормон, эстрогены/тестостерон, } \\
\text { гормон щитовидной железы }\end{array}$ \\
\hline 2-й год от окончания терапии & $\begin{array}{l}\text { • Осмотр, анализы и КТ каждые } 6 \text { мес } \\
\text { • Ежегодно - исследование молочных желез, оценка функции сердца, легких, щитовидной железы } \\
\text { и гормонального статуса }\end{array}$ \\
\hline 3-й год от окончания терапии & $\begin{array}{l}\text { • Осмотр, анализы и КТ каждые } 12 \text { мес } \\
\text { • Ежегодно - исследование молочных желез, оценка функции сердца, легких, щитовидной железы } \\
\text { и гормонального статуса }\end{array}$ \\
\hline 4-й год от окончания терапии & То же \\
\hline 5-й год от окончания терапии & Переход под наблюдение в катамнестическую службу \\
\hline
\end{tabular}




\begin{tabular}{|c|c|}
\hline Рак молочной железы & $\begin{array}{l}\text { Самообследование ежемесячно после пубертата + клиническое обследование ежегодно, } \\
\text { начиная с пубертата. Маммограффия через } 8 \text { лет после лт или с 25-летнего возраста }\end{array}$ \\
\hline Болезни щитовидной железы & $\begin{array}{l}\text { Пациенты после облучения } 25 \text { Гр и выше - группа риска развития узлов и рака, } \\
\text { после уже } 20 \text { Гр - риск гипотиреоза. Ежегодный осмотр и ТТГ/Т4 для всех }\end{array}$ \\
\hline Болезни легких & $\begin{array}{l}\text { Пациенты после облучения грудной клетки и блеомицина* - группа риска. Рентгенография органов } \\
\text { грудной клетки и ФВД базово, перед любым наркозом и по потребности (симптоматика) }\end{array}$ \\
\hline Другие опухоли & $\begin{array}{l}\text { Все те, кто получал ЛТ - в группе риска рака кожи. Ежегодный осмотр с напоминанием } \\
\text { о солнцезащитных мероприятиях }\end{array}$ \\
\hline $\begin{array}{l}\text { Бесплодие или недостаточность } \\
\text { яичников }\end{array}$ & $\begin{array}{l}\text { Выше всего риск у мужчин, получавших } 3 \text { или более циклов прокарбазином, более } 7,5 \text { г/м } \\
\text { циклофоссрамида* или облучение таза/яичек } \\
\text { Менархе чаще всего наступает, но лютеинизирующий гормон, фолликулостимулирующий гормон } \\
\text { и эстрадиол могут говорить о незрелой функции яичников } \\
\text { У мужчин редко снижен тестостерон, даже если они бесплодны, фолликулостимулирующий гормон } \\
\text { повышен }\end{array}$ \\
\hline
\end{tabular}

\begin{tabular}{|c|c|c|c|}
\hline \multicolumn{4}{|c|}{$\begin{array}{l}\text { Таблица 5.4. Скрининг по кардиотоксическим эффектам } \\
\text { Table 5.4. Cardiotoxicity screening }\end{array}$} \\
\hline \multicolumn{4}{|c|}{ Функция сердца } \\
\hline Возраст, лет & Облучение средостения & Доза антрациклинов, мг/м² & ЭхоКГ \\
\hline \multirow{3}{*}{$<1$} & + & Любая & 1 раз в год \\
\hline & \multirow{2}{*}{-} & $<200$ & Каждые 2 года \\
\hline & & $>200$ & 1 раз в год \\
\hline \multirow{4}{*}{$1-4$} & + & Любая & 1 раз в год \\
\hline & \multirow{3}{*}{-} & $<100$ & Каждые 5 лет \\
\hline & & $100-300$ & Каждые 2 года \\
\hline & & $>300$ & 1 раз в год \\
\hline \multirow{5}{*}{$>5$} & \multirow{2}{*}{+} & $<300$ & Каждые 2 года \\
\hline & & $>300$ & 1 раз в год \\
\hline & \multirow{3}{*}{-} & $<200$ & Каждые 5 лет \\
\hline & & $200-300$ & Каждые 2 года \\
\hline & & $>300$ & 1 раз в год \\
\hline
\end{tabular}

\section{Организация медицинской помощи}

Медицинская помощь, за исключением медицинской помощи в рамках клинической апробации, в соответствии с Федеральным законом от 21.11.2011 №323-Ф3 (ред. от 25.05.2019) «Об основах охраны здоровья граждан в Российской Федерации» организуется и оказывается:

1) в соответствии с положением об организации оказания медицинской помощи по видам медицинской помощи, которое утверждается уполномоченным федеральным органом исполнительной власти;

2) в соответствии с порядком оказания помощи по профилю «онкология», обязательным для исполнения на территории РФ всеми медицинскими организациями;

3) на основе настоящих клинических рекомендаций;

4) с учетом стандартов медицинской помощи, утвержденных уполномоченным федеральным органом исполнительной власти.

Первичная специализированная медико-санитарная помощь оказывается врачом-онкологом и иными врачамиспециалистами в центре амбулаторной онкологической помощи либо в первичном онкологическом кабинете, первичном онкологическом отделении, поликлиническом отделении онкологического диспансера.

При выявлении у пациента ЛХ или подозрении на него врачи-терапевты, врачи-терапевты участковые, врачи общей практики (семейные врачи), врачи-специалисты, средние медицинские работники в установленном порядке направляют пациента на консультацию в центр амбулаторной онкологической помощи либо в первичный онкологический кабинет, первичное онкологическое отделение медицинской организации для оказания ему первичной специализированной медико-санитарной помощи.
Консультация в центре амбулаторной онкологической помощи либо в первичном онкологическом кабинете, первичном онкологическом отделении медицинской организации должна быть проведена не позднее 5 рабочих дней с даты выдачи направления на консультацию. Врач-онколог центра амбулаторной онкологической помощи (в случае отсутствия центра амбулаторной онкологической помощи врач-онколог первичного онкологического кабинета или первичного онкологического отделения) организует взятие биопсийного (операционного) материала, а также организует выполнение иных диагностических исследований, необходимых для установления диагноза, включая распространенность онкологического процесса и стадию заболевания.

В случае невозможности взятия в медицинской организации, в составе которой организован центр амбулаторной онкологической помощи (первичный онкологический кабинет, первичное онкологическое отделение), биопсийного (операционного) материала, проведения иных диагностических исследований пациент направляется лечащим врачом в онкологический диспансер или в медицинскую организацию, оказывающую медицинскую помощь пациентам с онкологическими заболеваниями.

Срок выполнения патологоанатомических исследований, необходимых для гистологической верификации злокачественного новообразования, не должен превышать 15 рабочих дней с даты поступления биопсийного (операционного) материала в патологоанатомическое бюро (отделение).

При выявлении ЛХ или подозрении на него в ходе оказания скорой медицинской помощи пациента переводят или направляют в медицинские организации, оказывающие ме- 
дицинскую помощь пациентам с онкологическими заболеваниями, для определения тактики ведения и необходимости применения дополнительно других методов специализированного противоопухолевого лечения.

Врач-онколог центра амбулаторной онкологической помощи (первичного онкологического кабинета, первичного онкологического отделения) направляет пациента в онкологический диспансер или в медицинские организации, оказывающие медицинскую помощь пациентам с онкологическими заболеваниями, для уточнения диагноза (в случае невозможности установления диагноза, включая распространенность онкологического процесса и стадию заболевания, врачом-онкологом центра амбулаторной онкологической помощи, первичного онкологического кабинета или первичного онкологического отделения) и оказания специализированной, в том числе высокотехнологичной, медицинской помощи.

Срок начала оказания специализированной, за исключением высокотехнологичной, медицинской помощи пациентам с онкологическими заболеваниями в медицинской организации, оказывающей медицинскую помощь пациентам с онкологическими заболеваниями, не должен превышать 14 календарных дней с даты гистологической верификации злокачественного новообразования или 14 календарных дней с даты установления предварительного диагноза ЛХ (в случае отсутствия медицинских показаний к проведению патологоанатомических исследований в амбулаторных условиях).

Специализированная, в том числе высокотехнологичная, медицинская помощь оказывается врачами-онкологами, врачами-гематологами, врачами-радиотерапевтами в онкологическом диспансере или в медицинских организациях, оказывающих медицинскую помощь пациентам с ЛХ, имеющих лицензию, необходимую материально-техническую базу, сертифицированных специалистов, в стационарных условиях и условиях дневного стационара и включает в себя профилактику, диагностику, лечение онкологических заболеваний, требующих использования специальных ме- тодов и сложных уникальных медицинских технологий, а также медицинскую реабилитацию.

В медицинской организации, оказывающей медицинскую помощь пациентам с ЛХ, тактика медицинского обследования и лечения устанавливается консилиумом врачейонкологов и врачей-радиотерапевтов с привлечением при необходимости других врачей-специалистов. Решение консилиума врачей оформляется протоколом, подписывается участниками консилиума врачей и вносится в медицинскую документацию пациента.

Показания к госпитализации в круглосуточный или дневной стационар медицинской организации, оказывающей специализированную, в том числе высокотехнологичную, медицинскую помощь по профилю «онкология», определяются консилиумом врачей-онкологов и врачей-радиотерапевтов с привлечением при необходимости других врачей-специалистов.

\section{Показания для плановой госпитализации:}

1. Начало специфической терапии.

2. Плановое продолжение специфической терапии.

3. Диагностические процедуры, для проведения которых необходимы стационарные условия.

\section{Показания для экстренной госпитализации:}

1. Осложнения основного заболевания, требующие специфического лечения в условиях стационара.

2. Осложнения специфической терапии, угрожающие жизни пациента и требующие соответствующего лечения в условиях стационара.

\section{Показания к выписке пациента из стационара:}

1. Окончание специфической терапии (при отсутствии осложнений специфической терапии, угрожающих жизни пациента).

Заключение о целесообразности перевода пациента в профильную медицинскую организацию составляется после предварительной консультации по предоставленным медицинским документам и/или предварительного осмотра пациента врачами-специалистами медицинской организации, в которую планируется перевод.

\section{https://doi.org/10.26442/18151434.2020.2.200172}

\section{6. Дополнительная информация, влияющая на течение и исход заболевания}

\section{1. Общие требования к морфологической} диагностике лимфом

До биопсии лимфатического узла необходимо выполнить ОАК с подсчетом лейкоцитарной формулы, чтобы исключить выполнение биопсии у пациентов хроническим лимфолейкозом, моноклональным В-клеточным лимфоцитозом, острыми лейкозами, при лимфоцитозе инфекционной (HIV, EBV, CMV-инфекции, коклюш, вирусные гепатиты, токсоплазмоз и др.) или другой этиологии (поствакцинальный, лекарственная реакция, курение, тимома, «стрессорный» лимфоцитоз).

Диагноз ЛХ устанавливают на основании морфологического и иммуногистохимического исследования биопсийного или операционного материала. В части случаев необходимо проведение молекулярно-биологических и генетических тестов. Цитологическое исследование пунктатов или мазков-отпечатков лимфатических узлов или других опухолевых очагов является дополнительным методом исследования и не может служить достаточным основанием для диагноза лимфомы и ее нозологической верификации.

При первичном обследовании пациента во всех случаях проводится гистологическое и иммуногистохимическое исследование материала инцизионной или эксцизионной биопсии патологического очага или операционного материала при обязательном предоставлении врачу-патологоанатому выписки из амбулаторной карты/истории болезни пациента. Пунктировать лимфатические узлы для аспирации клеточной взвеси не следует. В исключительных случаях (локализация опухоли в труднодоступных анатомических зонах, тяжесть состояния пациента) при обосновании невозможности выполнения эксцизионной биопсии (отраженном в медицинской документации), объектом исследования может быть тканевой материал, полученный с помощью пистолетной («кор»-) биопсии. Пригодным для исследования является биоптат диаметром не менее $16 \mathrm{G}$, при длине опухолевого инфильтрата в ткани не менее 1,5 см. Объем иммуногистохимического исследования определяет врач-патологоанатом при гистологическом изучении материала. Разделение материала между различными лабораториями категорически недопустимо. Протокол морфологического и иммуногистохимического исследования должен содержать:

1. Макроскопическое описание материала, присланного для исследования; при исследовании готовых блоков и микропрепаратов в протоколе должны быть указаны количество и идентификационные номера всех присланных объектов.

2. Гистологическое описание лимфомы с указанием типа роста (диффузный, нодулярный и т. п.), характеристики клеточного состава (мелкие, крупные клетки, полиморфный состав, анапластическая, бластная/бластоидная морфология, наличие многоядерных форм, характеристика ядер), наличия реактивных и резидуальных компонентов Для варианта «нодулярный склероз кЛХ» необходимо описание наличия, характера и выраженности фиброзного компонента и клеточного состава нодулей. Для НЛПЛХ необходимо описание клеточного состава нодулей и указание на наличие/отсутствие фиброзного компонента.

3. Результаты иммуногистохимического исследования с указанием использованных антител и подробностей окрашивания, указывающих на специфический характер реакции (например, окрашивание ядер в реакциях с антителами к TdT, BCL-6, Cyclin D1; цитоплазмы - в реакциях на CD79a; гранулярная цитоплазматическая реакция - цитотоксические молекулы; окрашивание цитоплазмы или мембраны в реакциях с антителами к $\mathrm{CD} 3$, тяжелым или легким цепям 
Ig; мембраны - в реакциях на CD20, CD10), интенсивность, особенности иммуногистоархитектоники. Представление результатов иммуногистохимических тестов только в виде «крестов» («плюсов») и перечня антител недопустимо.

4. Патоморфологическое заключение, сформулированное в соответствии с действующей редакцией классификации опухолей гемопоэтической и лимфоидной тканей (ВО3, 2017 г.).

Обязательным компонентом определения распространенности опухолевого процесса (стадии) является гистологическое исследование трепанобиоптата костного мозга.
В процессе первичного обследования рекомендуется выполнять биопсию билатерально.

Морфологическое исследование пунктата костного мозга (стернального или др.) не заменяет гистологическое исследование трепанобиоптата.

Показания к трепанобиопсии для кЛХ и НЛПлХ описаны в разделе 2.5 .

При наличии в ОАК или миелограмме лимфоцитоза, независимо от числа лейкоцитов, а также при преобладании лимфоидных клеточных элементов, атипичных лимфоцитов или клеток с бластной морфологией в плевраль-

\begin{tabular}{|c|c|c|}
\hline Лх & Варианты & Иммунофенотип опухолевого субстрата \\
\hline $\mathrm{k} Л \mathrm{X}$ & $\begin{array}{c}\text { С нодулярным склерозом, 1-2-й типы; } \\
\text { смешанно-клеточный; богатый лимфоцитами; } \\
\text { с лимфоидным истощением }\end{array}$ & $\begin{array}{c}\text { CD30+, CD15+, CD20-/+ (экспрессия в 20-40\% случаев), } \\
\text { CD45-, PAX-5+ (слабо), ВоВ.1-, Осt-2- } \\
\text { (или окрашивание в части клеток) }\end{array}$ \\
\hline нЛПлх & & $\begin{array}{c}\text { CD20+, CD45+, CD30- (экспрессирован в единичных случаях), } \\
\text { CD15-, Oct-2+ (очень ярко), BoB.1+, BCL-6+, J- chain+ }\end{array}$ \\
\hline
\end{tabular}

\begin{tabular}{|c|c|c|}
\hline І стадия & • Поражение одной лимфатической зоны (рис. 6.3.1) или структуры ${ }^{1}$ & $n$ m $n$ m \\
\hline II стадия & - Поражение двух или более лимфатических зон по одну сторону диафрагмы ${ }^{3}$ & \\
\hline III стадия & • Поражение лимфатических узлов или структур по обе стороны диафрагмы ${ }^{4}$ & \\
\hline IV стадия & $\begin{array}{l}\text { - Диссеминированное (многофокусное) поражение одного или нескольких экстралимфатических } \\
\text { органов с или без поражения лимфатических узлов } \\
\text { - Изолированное поражение экстралимфатического органа с поражением отдаленных } \\
\text { (не регионарных) лимфатических узлов } \\
\text { - Поражение печени и/или костного мозга }\end{array}$ & \\
\hline & Для всех стадий & \\
\hline A & • Отсутствие признаков В-стадии & \\
\hline $\mathrm{B}^{5}$ & $\begin{array}{l}\text { Один или более из следующих симптомов: } \\
\text { • Лихорадка выше } 38^{\circ} \mathrm{C} \text { не менее } 3 \text { дней подряд без признаков воспаления } \\
\text { • Ночные профузные поты } \\
\text { • Похудение на } 10 \% \text { массы тела за последние } 6 \mathrm{mec}\end{array}$ & \\
\hline$E^{6}$ & $\begin{array}{l}\text { - Локализованное (единственное) экстранодальное поражение (только при I-ІІ стадиях): } \\
\text { - Локализованное поражение одного экстралимфатического органа или ткани в пределах одного } \\
\text { сегмента с поражением только региональных лимфатических узлов } \\
\text { - При I или II стадиях с ограниченным экстранодальным вовлечением прилежащего органа или ткани }\end{array}$ & \\
\hline S & • Поражение селезенки (при I-III стадиях) & a n \\
\hline$X^{7}$ & $\begin{array}{l}\text { • Массивное (bulky) опухолевое поражение - очаг более } 10 \text { см в диаметре или медиастинально- } \\
\text { торакальный индекс }{ }^{8} \text { более } 1 / 3\end{array}$ & 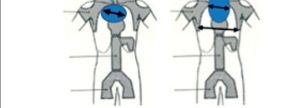 \\
\hline \multicolumn{3}{|c|}{ 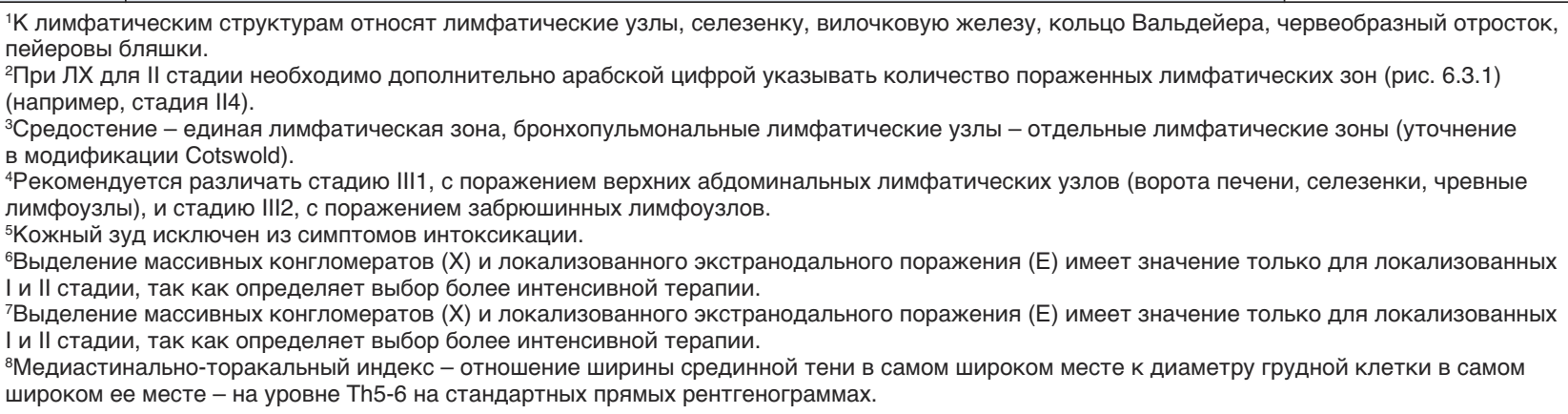 } \\
\hline
\end{tabular}


ной, асцитической или других биологических жидкостях необходимо выполнить иммунофенотипирование методом проточной цитометрии. Проточная цитометрия позволяет быстро провести дифференциальную диагностику опухолевого и реактивного лимфоцитоза, что важно для определения дальнейшей тактики обследования пациента. Материалом для анализа методом проточной цитометрии могут служить клетки крови, костного мозга, выпотных жидкостей, бронхоальвеолярного смыва, ликвора, гомогенизированные образцы тканей (селезенка, лимфатические узлы и т. д.), клеточная суспензия, полученная при аспирационной тонкоигольной пункции лимфатических узлов.

При определении стадии опухолевого процесса может потребоваться биопсия других очагов поражения, если нельзя исключить их опухолевую природу другими способами.

При рецидиве или прогрессировании заболевания обязательно выполнение повторной биопсии и морфологического исследования пораженных лимфатических узлов или экстранодальных очагов. Повторная биопсия также показана при наличии резидуальных очагов для подтверждения ремиссии, за исключением случаев ПЭТ-негативных резидуальных образований при ЛХ. Проведение повторной биопсии патологического очага является обязательным при первично-резистентном течении или рецидиве заболевания в целях подтверждения диагноза или верификации опухолевой трансформации, а также исключения второй опухоли, инфекционного процесса.

Повторная аспирация и трепанобиопсия костного мозга выполняются для плановой оценки результатов лечения и при появлении клинически немотивированных цитопении и лихорадки. Аспират костного мозга может быть информативен для оценки регенерации и диспластических изменений миелопоэза. У пациентов с поражением костного мозга цитологическое исследование пунктата для оценки изменений объема опухолевой инфильтрации не всегда информативно.

\section{2. Морфологическая и иммуногистохимическая диагностика ЛХ}

Все варианты кЛХ характеризуются одинаковым иммунофенотипом: CD30 (dot-like, мембранная, цитоплазматическая реакция), CD15 (dot-like, мембранная, цитоплазматическая реакция), PAX-5 (слабая ядерная реакция по сравнению c B-клетками реактивного микроокружения). В опухолевых клетках может обнаруживаться вирус Эпштейна-Барр (LMP1/EBER).

Экспрессия CD15 отмечается примерно в 85\% случаев ЛХ, PAX-5 - в 95\% случаев. При отсутствии экспрессии CD30 диагноз ЛХ сомнителен и требует углубленного иммуногистохимического исследования.

Опухолевые клетки в части случаев экспрессируют пан-В-клеточный маркер CD20 (гетерогенная по интенсивности мембранная реакция), CD19 (мембранная реакция);

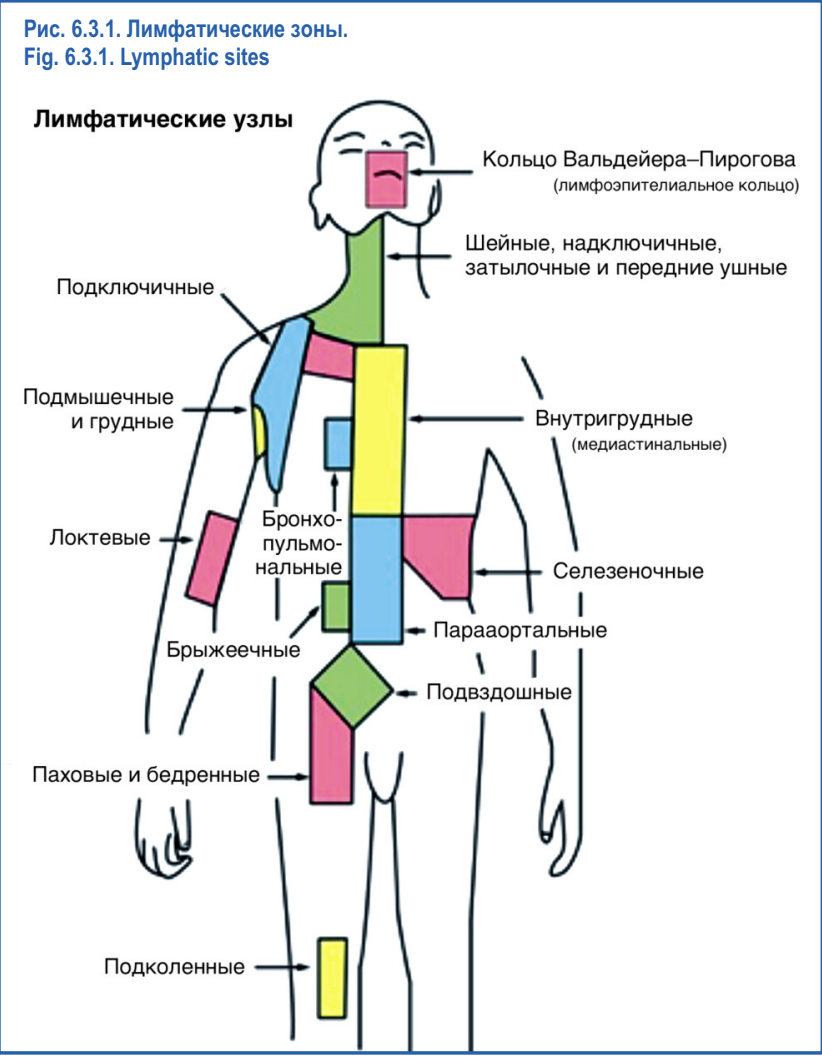

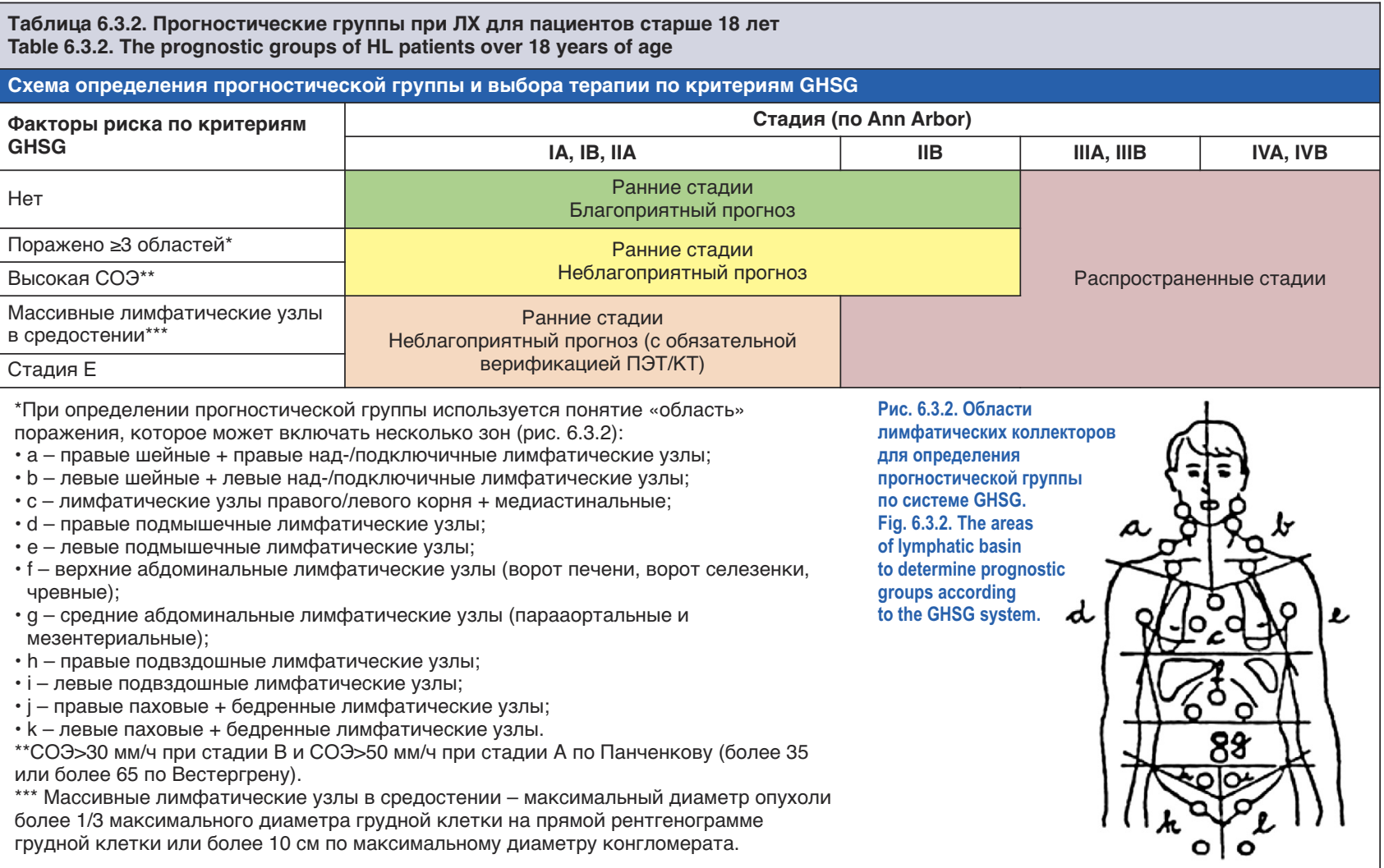




\begin{tabular}{|c|c|c|c|}
\hline \multicolumn{4}{|c|}{$\begin{array}{l}\text { Таблица 6.3.3. Определение терапевтических групп (риска) } \\
\text { для пациентов до } 18 \text { лет } \\
\text { Table 6.3.3. The identification of therapeutic groups (groups of risk) } \\
\text { of patients under } 18 \text { years of age }\end{array}$} \\
\hline \multirow{2}{*}{ Фактор риска } & \multicolumn{3}{|c|}{ Стадия, по Fnn Arbor } \\
\hline & I, IIA & IIB, IIIA & IIIB, IV \\
\hline Нет & TL-1 & \multirow{3}{*}{ TL-2 } & \multirow{4}{*}{ TL-3 } \\
\hline COЭ>30 мm/4 & \multirow{3}{*}{ TL-2 } & & \\
\hline Объем более 200 мл & & & \\
\hline E-поражения & & TL-3 & \\
\hline
\end{tabular}

Таблица 6.3.4. Международный прогностический индекс
Table 6.3.4. The International Prognostic Index
МПИ (каждый фактор = 1)
- Альбумин менее 40 г/л
- Гемоглобин менее 105 г/л
- Мужской пол
- Возраст $\geq 45$ лет
- IV стадия
- Лейкоцитоз $\geq 15 \times 10^{9} / л$
- Лимфопения менее $8 \%$ при подсчете формулы крови или менее
$0,6 \times 10^{9} / л$

экспрессия опухолевыми клетками CD45 и CD3 отсутствует. Дополнительным признаком, позволяющим отличить ЛХ от диффузной В-крупноклеточной лимфомы, является отсутствие экспрессии CD79a, BCL-6, B-клеточного транскрипционного фактора ВоB.1 (в части случаев наблюдается слабая ядерная реакция в отдельных опухолевых клетках).

При установлении диагноза кЛХ необходимо указать гистологический вариант и особенности иммунофенотипа (экспрессия CD20, EBV,); см. табл. 6.2.1. Иммуногистохимической верификации подлежат все случаи ЛХ.

НЛПЛХ отличается от кЛХ по клиническим и иммуноморфологическим характеристикам. Опухолевые (LP-) клетки одинаково интенсивно экспрессируют CD20, PAX-5, Oct-2 и другие В-клеточные антигены, их окружают розетки из CD3+, CD 57+, PD1+ TFH-лимфоцитов. Экспрессия CD30 и CD15 на опухолевых клетках отсутствует.

Согласно новой редакции классификации ВОЗ 2017 г., случаи ЛХ с наличием морфологических и иммунофенотипических признаков как кЛХ, так и НЛПЛХ следует относить к кЛХ, богатой лимфоцитами.

\section{3. Стадирование и определение прогностической группы при ЛХ}

Стадирование осуществляется по результатам обследования в соответствии с критериями классификации Ann Arbor (модификация Cotswold); табл. 6.3.1.

При установлении стадии лимфомы по критериям классификации Ann Arbor используется понятие «зона» (zone); рис. 6.3.1.

После завершения стадирования пациент должен быть отнесен к одной из прогностических групп: ранние стадии с благоприятным прогнозом, ранние стадии с неблагоприятным прогнозом и распространенные стадии (табл. 6.3.2, 6.3.3) согласно критериям Немецкой группы по изучению ЛX (GHSG). В группе пациентов с распространенными стадиями для выбора терапии может использоваться также МПИ (табл. 6.3.4).

\section{4. Оценка ответа на лечение при лимфомах}

Оценка ответа на лечение проводится в соответствии с обновленными критериями, предложенными Международной рабочей группой по лимфомам в 2007 г. [62].

$\underline{\Pi P:}$

1. Полное исчезновение всех проявлений заболевания, в том числе выявляемых при помощи лабораторных и лучевых методов диагностики, а также клинических симптомов, если они имели место до начала лечения

2. Размеры лимфатических узлов:

a) $\leqslant 1,5$ см по наибольшему диаметру, если до начала лечения размеры лимфатических узлов были больше $1,5 \mathrm{~cm}$; б) $\leqslant 1,0$ см по наиболышему диаметру, если до начала лечения размеры лимфатических узлов были 1,5-1,1 см.

3. Печень, селезенка, если были увеличены до начала лечения, не пальпируются, по данным лучевых методов объемные образования в них не выявляются.

4. Костный мозг без признаков опухолевого поражения Если результат морфологического исследования костного мозга неоднозначный, наличие или отсутствие поражения должно определяться иммуногистохимически.

Для ЛХ ПР считается подтвержденной, если достигнутый эффект сохраняется не менее 3 мес или констатируется дальнейшее улучшение.

Неуверенная ПР констатируется только у пациентов, которым не выполнялась ПЭТ/КТ для оченки эффекта:

1. Остаточные изменения, выявляемые только при помощи лучевых методов исследования (особенно это касается остаточных объемных образований в месте массивного опухолевого поражения, чаще всего в средостении), в случае сокращения опухоли более чем на 75\% от исходных размеров по сумме двух наибольших ее диаметров. Эти остаточные изменения не должны увеличиваться в течение более чем 3 мес.

2. По другим показателям - соответствие критериям ПР. 4P:

1. Уменьшение суммы диаметров всех измеряемых очагов (лимфоузлов и/или очагов экстранодального поражения) не менее чем на 50\%. Если размеры пораженных очагов менее 3 см по наибольшему диаметру, то 2 наиболыших очага должны уменьшиться не менее чем на 50\% по наибольшему диаметру. При наличии более чем 6 очагов поражения более 3 см достаточна оценка 6 наиболыших очагов, доступных четкому измерению в двух перпендикулярных направлениях. При наличии медиастинальных и/или ретроперитонеальных очагов поражения они обязательно должны учитываться при измерении.

2. Отсутствие новых очагов поражения, отсутствие признаков увеличения какого-либо из ранее диагностированных очагов поражения.

3. В случае исходного поражения костного мозга статус костного мозга для определения ЧР не значим. Однако при сохранении поражения костного мозга в процессе и/или после завершения лечения обязательно уточнение характеристики опухолевых клеток. Пациенты с исходным поражением костного мозга, у которых после завершения лечения клинически диагностируется ПР, но при этом сохраняется поражение костного мозга или костный мозг не может быть оценен, относятся к ЧР.

Стабилизачия

Показатели опухоли не соответствуют ни критериям ПР или ЧР, ни критериям прогрессирования.

Рецидив (после ПР) или прогрессирование (после чР или стабилизачии)

1. Появление новых очагов (увеличение лимфатических узлов или объемных образований экстранодальных локализаций) более 1,5 см в наибольшем измерении в процессе или после завершения лечения, вне зависимости от изменения размеров других очагов поражения.

2. Увеличение как минимум одного уже известного очага более чем на 25\% от минимального. Для очагов менее 1 см в наибольшем измерении - увеличение до 1,5 см и более.

\section{5. Особенности планирования дозы ЛТ} на критические структуры при облучении пациентов младше 18 лет

\section{Костная система}

Радиочувствительность является наибольшей у детей младшего возраста (до 6 лет) и в препубертатном периоде (11-13 лет). Следует ограничивать дозу на ростовые пластинки трубчатых костей (не более 20 Гр). Несимметричное облучение осевого скелета может привести к кифозу или сколиозу, тогда как симметричное облучение приводит к уменьшению роста. Чтобы избежать развития сколиоза, облучение позвоночника на всем протяжении PTV должно быть симметричным. Недопустимо создавать градиент дозы в телах позвонков более $20 \%$.

\section{Спинной мозг}

У детей до 6 лет центральная нервная система проходит процесс созревания и поэтому особенно радиочувствитель- 
на. Максимальная доза на шейный отдел спинного мозга не должна превышать 20 Гр. Следует избегать доз больше 30 Гр на спинной мозг, и индивидуальное планирование должно быть направлено на минимизацию дозы на спинной мозг без влияния на запланированную дозу в мишени.

\section{Легкие}

Толерантность легких у детей малоизучена и, по-видимому, существенно не различается у взрослых и детей школьного возраста. Доза, указанная в данных рекомендациях (12-15 Гр) для тотального облучения легкого, с малой вероятностью может привести к значительному ухудшению функции легких. Тем не менее облучение всего легкого в дозе 12 Гр у детей младше 6 лет может привести к постоянному снижению жизненной емкости легких.

\section{Сердце}

Нарушение функции миокарда и артерий может произойти после длительного латентного периода (20 лет и более) как отдаленное последствие радиационно-индуцированной пролиферации эндотелия. Нет четкой информации о влиянии возраста на момент облучения. Облучение сердца должно быть максимально сокращено, особенно в сочетании с применением кардиотоксических антрациклинов, которые могут снизить общую толерантность сердца. Возможен фиброз и кальциноз клапанов вплоть до образования пороков. Таким образом, облучаемый объем сердца и доза на сердце должны быть сведены к минимуму. Не рекомендуется превышение дозы на сердце 30 Гр.

\section{Молочные железы}

Поздних неблагоприятных детерминированных эффектов на полностью развитые молочные железы не следует ожидать. В то же время неразвитые ювенильные молочные железы обладают высокой радиочувствительностью. После облучения неразвитой молочной железы в дозе от 5 до 10 Гр может возникнуть гипоплазия или аплазия всей молочной железы или ее части в подростковом возрасте

\section{Почки}

Почки очень радиочувствительны. Нет четкой информации о влиянии возраста на момент облучения. Рекомендуемая толерантная доза облучения всей почки составляет 12 Гр. При облучении целого органа в данной дозе не ожидается никаких существенных долгосрочных неблагоприятных последствий. Частичное облучение почки (например, верхний левый полюс почки при облучении селезенки и ножки селезенки) в дозе 20 Гр или более может привести к фиброзу верхнего полюса почки и вызвать локальные функциональные нарушения.

\section{Печень}

Рекомендуется рассматривать толерантную дозу для всего органа 15 Гр. Это относится и к ЛТ печени при диссеминированном заболевании органа. Частичное облучение печени (например, при ЛТ верхней части парааортальной области) в дозах 20 Гр и более не приведет к клинически значимому снижению функции печени в целом.

\section{Щитовидная железа}

У пациентов может развиться субклинический гипотиреоз после латентного периода 3-4 года или более после облучения органа в дозе 20 Гр или более. Субклинический гипотиреоз может разрешиться спонтанно, и потребность проведения терапии в данном случае является спорной. Риск снижения функции щитовидной железы возрастает с увеличением дозы облучения до 30 Гр и может привести к клиническому гипотиреозу, который потребует проведения заместительной гормональной терапии.

\section{Яички}

Яички являются наиболее радиочувствительным органом. Доза 1-2 Гр может привести к необратимому нарушению сперматогенеза. Поэтому яички должны быть защищены во время облучения подвздошной и/или паховой областей с помощью современных методик облучения или путем прямого экранирования.

\section{Яичники}

После накопленной дозы 5-10 Гр в яичниках индуцируется гибель клеток ооцитов, что приводит к бесплодию. Эндокринная недостаточность возникает после достижения более высоких доз (около 10-15 Гр). В таких случаях может потребоваться заместительная гормональная терапия в зависимости от гормонального статуса в пубертатный период. Чтобы избежать нарушения функции яичников, по крайней мере один яичник должен быть защищен от действия в том числе и рассеянного излучения. Рекомендуется рассмотреть оперативное выведение яичников из полей предполагаемого облучения (овариопексия).

\section{Вторичные опухоли}

ЛТ в детском возрасте увеличивает риск развития широкого спектра вторичных опухолей. Наиболее часто встречается рак молочной железы у женщин, которым в детском возрасте проводилась ЛТ на область средостения и подмышечные области. В связи с этим рекомендуется регулярное обследование молочных желез на выявление рака у женщин старше 25 лет или через 8 лет после проведения ЛТ. После облучения шейных лимфоузлов повышается риск развития опухолей, в том числе злокачественных, щитовидной железы.

\section{Критерии оценки качества медицинской помощи}

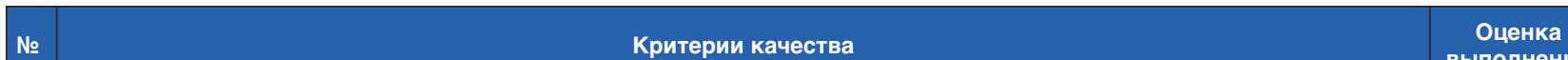

У пациента с подозрением на ЛХ или выявленной ЛХ при первичном или повторном приеме, после завершения каждого цикла терапии и перед началом каждого нового цикла терапии, при оценке ремиссии после завершения терапии,

1. при контрольных обследованиях, и при подозрении на рецидив заболевания выполнен развернутый клинический анализ крови с определением гемоглобина, эритроцитов, тромбоцитов, лейкоцитов, подсчетом лейкоцитарной формулы и количества ретикулоцитов

У пациента с подозрением на ЛХ или выявленной ЛХ при первичном или повторном приеме, после завершения каждого цикла терапии и перед началом каждого нового цикла терапии, при оценке ремиссии после завершения терапии,

2. при контрольных обследованиях, и при подозрении на рецидив заболевания выполнен анализ крови биохимический общетерапевтический с включением следующих параметров: ЛДГ, мочевина, креатинин, общий белок, альбумин, билирубин, АСТ, АЛТ, щелочная фосфатаза, калий, натрий, хлор, кальций

У пациента при установлении диагноза ЛХ, при оценке ответа на лечение, а также при подозрении на рецидив заболевания выполнена КТ грудной клетки, органов брюшной полости и малого таза (с контрастированием) либо

3. (при наличии противопоказаний к КТ либо при невозможности выполнения КТ) рентгенограсрия органов грудной клетки в двух проекциях и УЗИ лимфатических узлов и внутренних органов

Пациенту с подозрением на ЛХ выполнены биопсия лимфатического узла либо другого очага поражения

4. патологоанатомическое исследование биопсийного (операционного) материала с применением иммуногистохимических методов для верификации диагноза

Пациенту с ЛХ после 2 и 4-го циклов ХТ, после окончания химиотерапевтического этапа и после завершения всей

5. программы лечения выполнена оценка ответа на терапию в соответствии со стандартными критериями ответа на лечение лимфом 
1. Демина Е.А. и др. Общие принципы диагностики лимфом. Российские клинические рекомендации по диагностике и лечению злокачественных лимфопролиферативных заболеваний. Под ред. И.В. Поддубной, В.Г. Савченко. 2018; с. 9-27. [Demina E.A. et al. General principles for the diagnosis of lymphomas. Russian clinical guidelines for the diagnosis and treatment of malignant lymphoproliferative diseases. Pod red. I.V. Poddubnoi, V.G. Savchenko 2018; s. 9-27. (in Russian).]

2. Злокачественные новообразования в России в 2017 году (заболеваемость и смертность). Под ред. А.Д. Каприна, В.В. Старинского, Г.В. Петровой. М.: МНИОИ им. П.А. Герцена - филиал ФГБУ «НМИЦ радиологии» Минздрава России, 2018. [Malignant neoplasms in Russia in 2017 (morbidity and mortality). Pod red. A.D. Kaprina, V.V. Starinskogo, G.V. Petrovoi. Moscow: MNIOI im. P.A. Gertsena - filial FGBU "NMITS radiologii' Minzdrava Rossii, 201 (in Russian).]

3. Swerdlow SH et al. WHO classification of tumours of haematopoietic and lymphoid tissues. Revised 4th ed. Ed. Swerdlow SH, Campo E, Harris NL et al. Lyon, France: International Agency for Research in Cancer (IARC), 2017

4. Демина Е.А. и др. Лимфома Ходжкина. Российские клинические рекомендации по диагностике и лечению злокачественных лимфопролиферативных заболеваний. Под ред. И.В. Поддубной, В.Г. Савченко. 2018; с. 28-43.

[Demina E.A. et al. Hodgkin's lymphoma. Russian clinical guidelines for the diagnosis and treatment of malignant lymphoproliferative diseases. Pod red. I.V. Poddubnoi, V.G. Savchenko. 2018; c. 28-43 (in Russian).]

5. Kennedy-Nasser AA, Hanley P, Bollard CM. Hodgkin disease and the role of the immune system. Pediatr Hematol Oncol NIH Public Access 2011; 28 (3): 176-86.

6. Good RA. Relations between immunity and malignancy. Proceedings of the National Academy of Sciences of the United States of America. 1972; 69 (4): 1026-32.

7. Шмаков Р.Г., Демина Е.А. Лимсомы и беременность. Российские клинические рекомендации по диагностике и лечению злокачественных лимфопролиферативных заболеваний. Под ред. И.В. Поддубной, В.Г. Савченко. 2018; С. 143-50. [Shmakov R.G., Demina E.A. Lymphomas and pregnancy. Russian clinical guidelines for the diagnosis and treatment of malignant lymphoproliferative diseases. Pod red. I.V. Poddubnoi, V.G. Savchenko. 2018; s. 143-50 (in Russian).]

8. Kanoun S, Rossi C, Casasnovas O. [18F]FDG-PET/CT in hodgkin lymphoma: Current usefulness and perspectives. Cancers 2018

9. Yokoyama K. Thrombosis in lymphoma patients and in myeloma patients. Keio J Med. Keio University School of Medicine 2015; 64 (3): 37-43.

10. Криволапов Ю.А., Леенман Е.Е. Морфологическая диагностика лимфом. СПб: KOCTA, 2006

[Krivolapov lu.A., Leenman E.E. Morphological diagnosis of lymphomas.. Saint Petersburg: KOSTA, 2006 (in Russian).]

11. Adams HJA, Nievelstein RAJ, Kwee TC. Opportunities and limitations of bone marrow biopsy and bone marrow FDG-PET in lymphoma. Blood Rev Churchill Livingstone 2015; $29(6): 417-25$

12. Моисеева Т.Н., Аль-Ради Л.С., Дорохина Е.И. Протокол диагностики и лечения классической лимфомы Ходжкина. Алгоритмы диагностики и протоколы лечения заболеваний системы крови. Под ред. В.Г. Савченко. НМИЦ Гематологии. 2018; c. $39-56$.

[Moiseeva T.N., Al'-Radi L.S., Dorokhina E.I. Protocol for the diagnosis and treatment of classical Hodgkin lymphoma. Diagnostic algorithms and protocols for the treatment of diseases of the blood system. Pod red. V.G. Savchenko. NMITs Gematologii. 2018; c. 39-56 (in Russian).]

13. Engert $A$ et al. Two cycles of doxorubicin, bleomycin, vinblastine, and dacarbazine plus extended-field radiotherapy is superior to radiotherapy alone in early favorable Hodgkin's lymphoma: Final results of the GHSG HD7 trial. J Clin Oncol 2007; 200: 3495-502.

14. Meyer RM et al. ABVD alone versus radiation-based therapy in limited-stage Hodgkin's lymphoma. N Engl J Med 2012; 366 (5): 399-408.

15. Allen PB, Gordon LI. Frontline Therapy for Classical Hodgkin Lymphoma by Stage and Prognostic Factors. Clinical Medicine Insights: Oncology. SAGE Publications Ltd, 2017; 11.

16. Skoetz $\mathrm{N}$ et al. Comparison of first-line chemotherapy including escalated BEACOPP versus chemotherapy including ABVD for people with early unfavourable or advanced stage Hodgkin lymphoma. Cochrane Database of Systematic Reviews, 2017

17. Von Tresckow $B$ et al. Dose-intensification in early unfavorable Hodgkin's lymphoma: Final analysis of the German Hodgkin study group HD14 trial. J Clin Oncol 2012; 30 (9): 907-13.

18. Hoppe BS et al. Effective dose reduction to cardiac structures using protons compared with 3DCRT and IMRT in mediastinal Hodgkin lymphoma. Int J Radiat Oncol Biol Phys 2012; 84 (2): 449-55.

19. Hoppe BS et al. Consolidative proton therapy after chemotherapy for patients with Hodgkin lymphoma. Ann Oncol 2017; 28 (9): 2179-84.

20. Tseng YD et al. Evidence-based Review on the Use of Proton Therapy in Lymphoma From the Particle Therapy Cooperative Group (PTCOG) Lymphoma Subcommittee. Int J Radiat Oncol Biol Phys 2017; 99 (4): 825-42.

21. Engert $A$ et al. Reduced-intensity chemotherapy and PET-guided radiotherapy in patients with advanced stage Hodgkin's lymphoma (HD15 trial): a randomised, open-label, phase 3 non- inferiority trial. Lancet 2012; 379 (9828): 1791-9.
22. Демина Е.А. и др. Оптимизация терапии первой линии у пациентов с распространенными стадиями лимфомы Ходжкина: эфффективность и токсичность интенсивной схемы ЕАСОРР-14 (опыт ФГБУ «НМИЦ онкологии им. Н.Н. Блохина Минздрава России). Клиническая онкогематология. Фундаментальные исследования и клиническая практика. 2017; 10 (4): 443-52.

[Demina E.A. i dr. Optimizatsiia terapii pervoi linii u patsientov s rasprostranennymi stadiiami limfomy Khodzhkina: effektivnost' i toksichnost' intensivnoi skhemy EACOPP-14 (opyt FGBU "NMITs onkologii im. N.N. Blokhina Minzdrava Rossii). Klinicheskaia onkogematologiia. Fundamental'nye issledovaniia i klinicheskaia praktika. 2017; 10 (4): 443-52 (in Russian).]

23. Sieber $M$ et al. 14-Day variant of the bleomycin, etoposide, doxorubicin, cyclophosphamide, vincristine, procarbazine, and prednisone regimen in advanced-stage Hodgkin's lymphoma: Results of a pilot study of the German Hodgkin's Lymphoma Study Group. J Clin Oncol 2003; 21 (9): 1734-9.

24. Gallamini $A$ et al. Consolidation radiotherapy could be omitted in advanced Hodgkin lymphoma with large nodal mass in complete metabolic response after ABVD. Final analysis of the randomized HD0607 trial. Hematol Oncol Wiley 2019; 37: 147-8.

25. Barrington SF et al. PET-CT for staging and early response: Results from the ResponseAdapted Therapy in Advanced Hodgkin Lymphoma study. Blood Am Soc Hematol 2016; 127 (12): 1531-8.

26. Wedgwood A, Younes A. Prophylactic use of filgrastim with ABVD and BEACOPP chemotherapy regimens for Hodgkin lymphoma. Clin Lymphoma Myeloma 2007; 8 (Suppl. 2): S63-6.

27. Engel $\mathrm{C}$ et al. Acute hematologic toxicity and practicability of dose-intensified BEACOPP chemotherapy for advanced stage Hodgkin's disease. German Hodgkin's Lymphoma Study Group (GHSG). Ann Oncol Off J Eur Soc Med Oncol 2000; 11 (9): 1105-14.

28. Lymphoma H. NCCN Clinical Practice Guidelines in Oncology (NCCN Guidelines ${ }^{\circledR}$ ) NCCN.org NCCN Guidelines for Patients ${ }^{\circledR}$ available at www.nccn.org/patients. 2019.

29. Yahalom $J$ et al. Modern radiation therapy for extranodal lymphomas: Field and dose guidelines from the international lymphoma radiation oncology group. Int $J$ Radiat Oncol Biol Phys 2015; 92 (1): 11-31.

30. Connors JM et al. Brentuximab vedotin with chemotherapy for stage III or IV Hodgkin's Iymphoma. N Engl J Med 2018; 378 (4): 331-44.

31. Mauz-Körholz $C$ et al. Procarbazine-free OEPA-COPDAC chemotherapy in boys and standard OPPA-COPP in girls have comparable effectiveness in pediatric Hodgkin's lymphoma: The GPOH-HD-2002 study. J Clin Oncol 2010; 28 (23): 3680-6.

32. Dörffel $W$ et al. Treatment of children and adolescents with hodgkin lymphoma without radiotherapy for patients in complete remission after chemotherapy: Final results of the multinational trial GPOH-HD95. J Clin Oncol 2013; 31 (12): 1562-8.

33. Hudson MM, Constine LS. Refining the role of radiation therapy in pediatric hodgkin lymphoma. Am Soc Clin Oncol Educ Book. From the Department of Oncology, Division of Cancer Survivorship, St. Jude's Children's Research Hospital, Memphis, TN; Departments of Radiation Oncology and Pediatrics, Philip Rubin Center for Cancer Survivorship, James P. Wilmot Cancer Center at Univers: American Society of Clinical Oncology, 2012; p. 616-20.

34. International Commission on Radiation Units and Measurments. Prescribing, Recording, and Reporting Photon Beam Therapy (Supplement to ICRU Report 50). 1999.

35. Румянцев А.Г., Самочатова Е.В. Практическое руководство по детским болезням. Гематология/онкология детского возраста. М.: Медпрактика-М, 2004. [Rumiantsev A.G., Samochatova E.V. A practical guide to childhood illnesses. Pediatric Hematology /Oncology. Moscow: Medpraktika-M, 2004 (in Russian).]

36. Borchmann S, Engert A, Böll B. Hodgkin lymphoma in elderly patients. Curr Opin Oncol 2018; 30 (5): 308-16.

37. Thyss $A$ et al. Hodgkin's lymphoma in older patients: An orphan disease? Mediterr $\mathrm{J} H \mathrm{He}$ matol Infect Dis 2014; 6 (1): 1-10.

38. Капланов К.Д. и др. Программа IVDG - возможный выбор первой линии терапии лимфомы Ходжкина у пациентов пожилого возраста с сопутствующими сердечнососудистыми и легочными заболеваниями. Клин. онкогематология. 2017; 10 (3): 358-65.

[Kaplanov K.D. et al. Programma IVDG - vozmozhnyi vybor pervoi linii terapii limfomy Khodzhkina u patsientov pozhilogo vozrasta s soputstvuiushchimi serdechno-sosudistymi i legochnymi zabolevaniiami. Klin. onkogematologiia. 2017; 10 (3): 358-65 (in Russian).]

39. Fedele R et al. Clinical Options in Relapsed or Refractory Hodgkin Lymphoma: An Updated Review. J Immunol Res 2015; 2015: 968212

40. Nikolaenko L, Chen R, Herrera AF. Current strategies for salvage treatment for relapsed classical Hodgkin lymphoma. Ther Adv Hematol 2017; 8 (10): 293-302.

41. Mohty $M$ et al. Autologous haematopoietic stem cell mobilisation in multiple myeloma and lymphoma patients: A position statement from the European Group for Blood and Marrow Transplantation. Bone Marrow Transplant 2014; 20: 295-308.

42. Moskowitz AJ et al. Pretransplantation functional imaging predicts outcome following autologous stem cell transplantation for relapsed and refractory Hodgkin lymphoma. Blood 2010; 116 (23): 4934-7.

43. Moskowitz $\mathrm{CH}$ et al. Five-year PFS from the AETHERA trial of brentuximab vedotin for Hodgkin lymphoma at high risk of progression or relapse. Blood 2018; 132 (25): 2639-42. 
44. Chen $R$ et al. Five-year survival and durability results of brentuximab vedotin in patients with relapsed or refractory Hodgkin lymphoma. Blood 2016; 128 (12): 1562-6.

45. Younes $A$ et al. Nivolumab for classical Hodgkin's lymphoma after failure of both autologous stem-cell transplantation and brentuximab vedotin: a multicentre, multicohort, singlearm phase 2 trial. Lancet Oncol 2016; 17 (9): 1283-94.

46. Chen $R$ et al. Pembrolizumab in relapsed or refractory Hodgkin lymphoma: 2-year followup of KEYNOTE-087. Blood. Am Soc Hematol 2019; 134 (14): 1144-53.

47. Rashidi A, Ebadi M, Cashen AF. Allogeneic hematopoietic stem cell transplantation in Hodgkin lymphoma: a systematic review and meta-analysis. Bone Marrow Transplant 2016: 51 (4): 521-8.

48. Peggs KS. Should all patients with Hodgkin lymphoma who relapse after autologous SCT be considered for allogeneic SCT? Blood Adv Am Soc Hematol 2018; 2 (7): 817-20.

49. Wirth $A$ et al. Long-term outcome after radiotherapy alone for lymphocyte-predominant Hodgkin lymphoma: a retrospective multicenter study of the Australasian Radiation Oncology Lymphoma Group. Cancer 2005; 104 (6): 1221-9.

50. Nogová $L$ et al. Extended field radiotherapy, combined modality treatment or involved field radiotherapy for patients with stage IA lymphocyte-predominant Hodgkin's lymphoma: a retrospective analysis from the German Hodgkin Study Group (GHSG). Ann Oncol Off J Eur Soc Med Oncol 2005; 16 (10): 1683-7.

51. Eichenauer DA et al. Phase 2 study of rituximab in newly diagnosed stage IA nodular lymphocytepredominant Hodgkin lymphoma: A report from the German Hodgkin Study Group. Blood 2011; 118 (16): 4363-5.

52. Appel BE et al. Minimal treatment of low-risk, pediatric lymphocyte-predominant hodgkin lymphoma: A report from the children's oncology group. J Clin Oncol 2016; 34 (20): 2372-9.

53. Mauz-Körholz $C$ et al. Resection alone in 58 children with limited stage, lymphocyte-predominant Hodgkin lymphoma-experience from the European network group on pediatric Hodgkin lymphoma. Cancer 2007; 110 (1): 179-85.

54. Cencini E, Fabbri A, Bocchia M. Rituximab plus ABVD in newly diagnosed nodular lymphocyte-predominant Hodgkin lymphoma. Br J Haematol 2017; 176 (5): $831-3$.

55. Shankar $A$ et al. Treatment outcome after low intensity chemotherapy [CVP] in children and adolescents with early stage nodular lymphocyte predominant Hodgkin's lymphoma An Anglo-French collaborative report. Eur J Cancer 2012; 48 (11): 1700-6.

56. Fanale $M A$ et al. Encouraging activity for $R-C H O P$ in advanced stage nodular lymphocytepredominant Hodgkin lymphoma. Blood 2017; 130: 472-7.

57. Advani $R H$, Hoppe RT. How $i$ treat nodular lymphocyte predominant Hodgkin lymphoma. Blood 2013; 122 (26): 4182-8.

58. Eichenauer DA et al. Relapsed and refractory nodular lymphocyte-predominant Hodgkin lymphoma: An analysis from the German Hodgkin Study Group. Blood 2018; 132 (14): 1519-25.

59. Eichenauer DA, Engert A. Nodular lymphocyte-predominant Hodgkin lymphoma: $A$ unique disease deserving unique management. Hematology 2017; 2017 (1): 324-8.

60. Bachanova V, Connors JM. Hodgkin lymphoma in pregnancy. Curr Hematol Malig Rep 2013; 8 (3): 211-7.

61. Avilés A, Neri N, Nambo MJ. Hematological malignancies and pregnancy: Treat or no treat during first trimester. Int J Cancer 2012; 131 (11): 2678-83.

62. Cheson BD et al. Revised response criteria for malignant lymphoma. J Clin Oncol 2007; 25 (5): 579-86.

63. Барях Е.А., Мякова Н.В., Поддубная И.В. Профилактика и лечение синдрома лизиса опухоли. Российские клинические рекомендации по диагностике и лечению злокачественных лимфопролиферативных заболеваний. Под ред. И.В. Поддубной, В.Г. Савченко. 2018; с. 251-3.

[Bariakh E.A., Miakova N.V., Poddubnaia I.V. Prevention and treatment of tumor lysis syndrome. Russian clinical guidelines for the diagnosis and treatment of malignant lymphoproliferative diseases. Pod red. I.V. Poddubnoi, V.G. Savchenko. 2018; s. 251-3 (in Russian).]

64. Аарro М и др. Клинические рекомендации по лечению анемии у больных злокачественными новообразованиями. М.: Ассоциация онкологов России, 2014. [Aapro $\mathrm{M}$ et al. Clinical recommendations for the treatment of anemia in patients with malignant neoplasms. Moscow: Assotsiatsiia onkologov Rossii, 2014 (in Russian).]

65. Орлова Р.В. и др. Практические рекомендации по лечению анемии при злокачественных новообразованиях. Практические рекомендации Российского общества клинической онкологии. Лекарственное лечение злокачественных опухолей. Поддерживающая терапия в онкологии. 2018; c. 494-501.

IOrlova R.V. et al. Practical recommendations for the treatment of anemia in malignant neoplasms. Practical recommendations of the Russian Society of Clinical Oncology. Lekarstvennoe lechenie zlokachestvennykh opukholei. Podderzhivaiushchaia terapiia $v$ onkologii. 2018; s. 494-501 (in Russian).]

66. Владимирова Л.Ю. и др. Практические рекомендации по профилактике и лечению тошноты и рвоты у онкологических больных. Практические рекомендации Российского общества клинической онкологии. Лекарственное лечение злокачественных опухолей. Поддерживающая терапия в онкологии. 2018; с. 502-11.

[Vladimirova L.lu. et al. Prakticheskie rekomendatsii po profilaktike i lecheniiu toshnoty i rvoty u onkologicheskikh bol'nykh. Prakticheskie rekomendatsii Rossiiskogo obshchestva klinicheskoi onkologii. Lekarstvennoe lechenie zlokachestvennykh opukholei. Podderzhivaiushchaia terapiia v onkologii. 2018; s. 502-11 (in Russian).]

67. Константинова Т.С., Клясова Г.А., Капланов К.Д. Лечение и профилактика инфекционных осложнений у пациентов с лимфопролиферативными заболеваниями. Российские клинические рекомендации по диагностике и лечению злокачественных лимфопролиферативных заболеваний. Под ред. И.В. Поддубной, В.Г. Савченко. 2018; с. 289-311.

[Konstantinova T.S., Kliasova G.A., Kaplanov K.D. Treatment and prevention of infectious complications in patients with lymphoproliferative diseases. Russian clinical guidelines for the diagnosis and treatment of malignant lymphoproliferative diseases. Pod red. I.V. Poddubnoi, V.G. Savchenko. 2018; s. 289-311 (in Russian).]

68. Srivastava $S$, Wood P. Secondary antibody deficiency-causes and approach to diagnosis. Clin Med J R Coll Physicians 2016; 16: 571-6.

69. Traila $A$ et al. Fertility preservation in hodgkin's lymphoma patients that undergo targeted molecular therapies: An important step forward from the chemotherapy era. Cancer Manag Res 2018; 10: 1517-26.

70. Meirow $D$, Nugent $D$. The effects of radiotherapy and chemotherapy on female reproduction. Hum Reprod Update 2001; 7 (6): 535-43.

71. Абузарова Г.Р. и др. Обезболивание взрослых и детей при оказании медицинской помощи. Методические рекомендации. ФГБОУ ВО РНИМУ им. Н.И. Пирогова Минздрава России, 2016

[Abuzarova G.R. et al. Obezbolivanie vzroslykh i detei pri okazanii meditsinskoi pomoshchi. Metodicheskie rekomendatsii. FGBOU VO RNIMU im. N.I. Pirogova Minzdrava Rossii, 2016 (in Russian).]

72. Абузарова Г.Р. Лечение болевого синдрома у онкологических больных. Российские клинические рекомендации по диагностике и лечению злокачественных лимфопролиферативных заболеваний. Под ред. И.В. Поддубной, В.Г. Савченко. 2018; c. 278-88.

[Abuzarova G.R. Lechenie bolevogo sindroma u onkologicheskikh bol'nykh. Rossiiskie klinicheskie rekomendatsii po diagnostike i lecheniiu zlokachestvennykh limfoproliferativnykh zabolevanii. Pod red. I.V. Poddubnoi, V.G. Savchenko. 2018; s. 278-88 (in Russian).]

73. Paul KL. Rehabilitation and exercise considerations in hematologic malignancies. Am J Phys Med Rehabil 2011; 90: 5 (Suppl. 1): S88-94.

74. Hancock BW et al. ChIVPP alternating with PABIOE is superior to PABIOE alone in the initial treatment of advanced hodgkin's disease: Results of a british national lymphoma investigation/central lymphoma group randomized controlled trial. Br J Cancer 2001; 84 (10): 1293-300.

75. Pavlovsky $S$ et al. Randomized trial of CVPP for three versus six cycles in favorable-prognosis and CVPP versus AOPE plus radiotherapy in intermediate-prognosis untreated Hodgkin's disease. J Clin Oncol 1997; 15: 7: 2652-8.

76. Sieber $M$ et al. Treatment of advanced Hodgkin's disease with COPP/ABV/IMEP versus COPP/ABVD and consolidating radiotherapy: final results of the German Hodgkin's Lymphoma Study Group HD6 trial. Ann Oncol Off J Eur Soc Med Oncol 2004; 15 (2): 276-82.

77. Zallio $F$ et al. Reduced intensity VEPEMB regimen compared with standard ABVD in elderly Hodgkin lymphoma patients: results from a randomized trial on behalf of the Fondazione Italiana Linfomi (FIL). Br J Haematol 2016; 172 (6): 879-8.

78. Levis $A$ et al. Results of a low aggressivity chemotherapy regimen (CVP/CEB) in elderly Hodgkin's disease patients. Haematologica 1996; 81 (5): 450-6.

79. Santoro $A$ et al. Ifosfamide, gemcitabine, and vinorelbine: $A$ new induction regimen for refractory and relapsed Hodgkin's lymphoma. Haematologica 2007; 92, (1): 35-41.

80. Jeon SY et al. The effect of the dexamethasone, cytarabine, and cisplatin (Dhap) regimen on stem cell mobilization and transplant outcomes of patients with non-hodgkin's lymphoma who are candidates for up-front autologous stem cell transplantation. Korean J Intern Med 2018; 33 (6): 1169-81.

81. Ramzi M, Rezvani A, Dehghani M. GDP versus ESHAP Regimen in Relapsed and/or Refractory Hodgkin lymphoma: A Comparison Study. Int J Hematol Stem Cell Res 2015; 9 (1): $10-4$.

82. Hu B et al. Phase-I and randomized phase-II trial of panobinostat in combination with ICE (Ifosfamide, carboplatin, etoposide) in relapsed or refractory classical hodgkin lymphoma. Leuk Lymphoma 2018; 59 (4): 863-70.

83. Gutierrez $A$ et al. Gemcitabine and oxaliplatinum: An effective regimen in patients with refractory and relapsing Hodgkin lymphoma. Onco Targets Ther 2014; 7: 2093-100.

84. Schellong $\mathrm{G}$ et al. Salvage therapy of progressive and recurrent Hodgkin's disease: Results from a multicenter study of the pediatric DAL/GPOH-HD Study Group. J Clin Oncol 2005; 23 (25): 6181-9.

85. Long GV et al. Assessment of nivolumab exposure and clinical safety of $480 \mathrm{mg}$ every 4 weeks flat-dosing schedule in patients with cancer. Ann Oncol 2018; 29 (11): 2208-13.

86. Singer $S$ et al. BEAM versus BUCYVP16 Conditioning before Autologous Hematopoietic Stem Cell Transplant in Patients with Hodgkin Lymphoma. Biol Blood Marrow Transplant 2019; 25 (6): 1107-15.

87. Oken MM et al. Toxicity and response criteria of the Eastern Cooperative Oncology Group Am J Clin Oncol 1982; 5 (6): 649-55.

88. Meignan M, Gallamini A, Haioun C. Report on the First International Workshop on interimPET scan in lymphoma. Leuk Lymphoma 2009: 50 (8): 1257-60. 


\section{Приложение A1. Состав рабочей группы}

Демина Елена Андреевна - д-р мед. наук, проф., проф. каф. гематологии и клеточной терапии Института усовершенствования врачей ФГБУ «Национальный медико-хирургический центр им. Н.И. Пирогова» Минздрава России, член правления Российского общества онкогематологов

Тумян Гаяне Сергеевна - д-р мед. наук, проф., проф. каф. онкологии и паллиативной медицины ФГБОУ ДПО «Российская медицинская академия непрерывного профессионального образования» Минздрава России, вед. науч. сотр. отд-ния химиотерапии гемобластозов ФГБУ «Национальный медицинский исследовательский центр онкологии им. Н.Н. Блохина» Минздрава России, член правления Российского общества онкогематологов

Моисеева Татьяна Николаевна - канд. мед. наук, зав. консультативным гематологическим отд-нием с дневным стационаром по проведению интенсивной высокодозной химиотерапии ФГБУ «Национальный медицинский исследовательский центр гематологии», член Национального гематологического общества

Михайлова Наталья Борисовна - д-р мед. наук, рук. отд. клинической онкологии (химиотерапии) НИИ детской онкологии, гематологии и трансплантологии им. Р.М. Горбачевой ФГБОУ ВО «Первый Санкт-Петербургский государственный медицинский университет им. акад. И.П. Павлова» Минздрава России, член Российского общества онкогематологов

Мякова Наталья Валерьевна - Д-р мед. наук, проф., зам. глав. врача по лечебной работе, зав. отд-нием онкогематологии ФГБУ «Национальный медицинский исследовательский центр детской гематологии, онкологии и иммунологии им. Дмитрия Рогачева» Минздрава России, член Национального общества детских гематологов и онкологов

Румянцев Александр Григорьевич - акад. РАН, д-р мед. наук, проф., ген. дир. ФГБУ «Национальный медицинский исследовательский центр детской гематологии, онкологии и иммунологии им. Дмитрия Рогачева» Минздрава России, президент Национального общества детских гематологов и онкологов

Масчан Алексей Александрович - чл.-кор. РАН, д-р мед. наук, проф., зам. ген. дир. ФГБУ «Национальный медицинский исследовательский центр детской гематологии, онкологии и иммунологии им. Дмитрия Рогачева» Минздрава России, член правления Национального общества детских гематологов и онкологов

Капланов Камиль Даниялович - канд. мед. наук, зав. отд-нием гематологии ГБУЗ «Волгоградский областной клинический онкологический диспансер», ассистент каф. онкологии с курсом онкологии и гематологии ФУВ ФГБОУ ВО «Волгоградский государственный медицинский университет» Минздрава России, член Российского общества онкогематологов и Национального гематологического общества

Шмаков Роман Георгиевич - проф. РАН, д-р мед. наук, дир. института акушерства, ФГБУ «Национальный медицинский исследовательский центр акушерства, гинекологии и перинатологии им. акад. В.И. Кулакова» Минздрава России, член правления Российского общества акушеров-гинекологов

Фалалеева Наталья Александровна - д-р мед. наук, зав. отд-нием противоопухолевого лекарственного лечения, Медицинский радиологический научный центр им. А.Ф. Цыба - филиал ФГБУ «Национальный медицинский исследовательский центр радиологии» Минздрава России, член Ассоциации онкологов России и Российской ассоциации терапевтических радиационных онкологов

Птушкин Вадим Вадимович -д-р мед. наук, проф., зам. глав. врача по гематологии ГБУЗ «Городская клиническая больница им. С.П. Боткина», глав. внештатный специалистгематолог Департамента здравоохранения города Москвы, член Национального гематологического общества и Российского общества онкогематологов

Османов Евгений Александрович - д-р мед. наук, проф., зав. отд. гематологии и трансплантации костного мозга ФГБУ «Национальный медицинский исследовательский центр онкологии им. Н.Н. Блохина» Минздрава России, проф. каф. онкологии ФГАОУ ВО «Первый Московский госу- дарственный медицинский университет им. И.М. Сеченова» Минздрава России, член правления Российского общества онкогематологов

Поддубная Ирина Владимировна - акад. РАН, засл. деятель образования РФ, д-р мед. наук, проф., зав. каф. онкологии и паллиативной медицины, проректор по лечебной работе и международному сотрудничеству ФГБОУ ДПО «Российская медицинская академия непрерывного профессионального образования» Минздрава России, председатель Российского общества онкогематологов

Байков Вадим Валентинович - д-р мед. наук, проф. каф. патологической анатомии, зав. лаб. патоморфологии НИИ детской онкологии, гематологии и трансплантологии им. Р.М. Горбачевой ФГБОУ ВО «Первый Санкт-Петербургский государственный медицинский университет им. акад. И.П. Павлова» Минздрава России, член президиума Российского общества патологоанатомов, член правления Российского общества онкогематологов

Ковригина Алла Михайловна - д-р биол. наук, проф. каф. патологической анатомии, цитологии и молекулярной патологии Академии постдипломного образования ФГБУ ФНКЦ ФМБА России, зав. патологоанатомическим отд-нием ФГБУ «Национальный медицинский исследовательский центр гематологии» Минздрава России, член президиума Российского общества патологоанатомов, член правления Российского общества онкогематологов

Коновалов Дмитрий Михайлович - канд. мед. наук, зав. патологоанатомическим отд-нием ФГБУ «Национальный медицинский исследовательский центр детской гематологии, онкологии и иммунологии им. Дмитрия Рогачева» Минздрава России

Трофимова Оксана Петровна - д-р мед. наук, вед. науч. сотр. радиологического отд-ния ФГБУ «Национальный медицинский исследовательский центр им. Н.Н. Блохина» Минздрава России, доц. каф. онкологии ФГБОУ ДПО «Российская медицинская академия непрерывного профессионального образования» Минздрава России, член Российской ассоциации терапевтических радиационных онкологов

Сотников Владимир Михайлович - д-р мед. наук, рук лаб. лучевой терапии ФГБУ «Российский научный центр рентгенорадиологии» Минздрава России

Ильин Николай Васильевич - д-р мед. наук, проф., проф. каф. радиологии, хирургии и онкологии, глав. науч. сотр. отд. лучевых и комбинированных методов лечения ФГБУ «Российский научный центр радиологии и хирургических технологий им. акад. А.М. Гранова» Минздрава России

Виноградова Юлия Николаевна - д-р мед. наук, рук. отд. лучевых и комбинированных методов лечения, глав. науч. сотр. отд. лучевых и комбинированных методов лечения ФГБУ «Российский научный центр радиологии и хирургических технологий им. акад. А.М. Гранова» Минздрава России

Нечеснюк Алексей Владимирович - д-р мед. наук, зав. отд-нием лучевой терапии ФГБУ «Национальный медицинский исследовательский центр детской гематологии, онкологии и иммунологии им. Дмитрия Рогачева», член Национального общества детских гематологов и онкологов

Пархоменко Роман Алексеевич - д-р мед. наук, ст. науч. сотр. лаб. комплексных методов лечения онкологических заболеваний у детей ФГБУ «Российский научный центр рентгенорадиологии» Минздрава России

Стефанов Дмитрий Николаевич - науч. сотр. научноорганизационного отд., ФГБУ «Национальный медицинский исследовательский центр детской гематологии, онкологии и иммунологии им. Дмитрия Рогачева» Минздрава России, член Российского общества онкогематологов

Невольских Алексей Алексеевич - д-р мед. наук, зам. дир. по лечебной работе, Медицинский радиологический научный центр им. им. А.Ф. Цыба - филиал ФГБУ «Национальный медицинский исследовательский центр радиологии» Минздрава России

Иванов Сергей Анатольевич - проф. РАН, д-р мед. наук, дир., Медицинский радиологический научный центр им. им. А.Ф. Цыба - филиал ФГБУ «Национальный медицин- 
ский исследовательский центр радиологии» Минздрава России

Хайлова Жанна Владимировна - канд. мед. наук, зам. дир. по организационно-методической работе. Медицинский радиологический научный центр им. А.Ф. Цыба - фи- лиал ФГБУ «Национальный медицинский исследовательский центр радиологии» Минздрава России

Геворкян Тигран Гагикович - зам. дир. НИИ КЭР ФГБУ «Национальный медицинский исследовательский центр онкологии им. Н.Н. Блохина»

\section{Приложение А2. Методология разработки клинических рекомендаций}

Целевая аудитория данных клинических рекомендаций:

1. Врачи-гематологи.

2. Врачи-онкологи.

3. Врачи - детские онкологи.

4. Специалисты лучевой диагностики.

5. Студенты медицинских вузов.

Методология сбора доказательств

Методы, использованные для сбора/селекции доказательств:

• поиск публикаций в специализированных периодических печатных изданиях с импакт-фактором более 0,3 ;

- поиск в электронных базах данных.

Базы данных, использованных для сбора/селекции доказательств. Доказательной базой для рекомендаций являются публикации, вошедшие в Кокрейновскую библиотеку, базы данных Pubmed и Medline. Глубина поиска составляла 30 лет.

Методы, использованные для анализа доказательств: - обзоры опубликованных метаанализов;

• систематические обзоры с таблицами доказательств,
Методы, использованные для качества и силы доказательств:

- консенсус экспертов;

- оценка значимости доказательств в соответствии с рейтинговой схемой доказательств (табл. А2.1, А2.2).

В настоящих клинических рекомендациях в скобках приведены уровни доказательности рекомендаций в соответствии со шкалами, разработанными Американским обществом клинической онкологии (ASCO) и Европейским обществом медицинской онкологии (ESMO).

\section{Методология валидизации рекомендаций}

Методы валидизации рекомендаций:

- внешняя экспертная оценка;

- внутренняя экспертная оценка.

Описание методики валидизации рекомендаций. Настоящие рекомендации в предварительной версии рецензированы независимыми экспертами, которых попросили прокомментировать, насколько качественно интерпретированы доказательства и разработаны рекомендации Также проведена экспертная оценка изложения рекомендаций и их доступности для понимания.

\begin{tabular}{|c|c|}
\hline удД & Расшифровка \\
\hline 1 & $\begin{array}{l}\text { Систематические обзоры исследований с контролем референсным методом или систематический обзор } \\
\text { рандомизированных клинических исследований с применением метаанализа }\end{array}$ \\
\hline 2 & $\begin{array}{l}\text { Отдельные исследования с контролем референсным методом или отдельные рандомизированные клинические } \\
\text { исследования и систематические обзоры исследований любого дизайна, за исключением рандомизированных } \\
\text { клинических исследований с применением метаанализа }\end{array}$ \\
\hline 3 & $\begin{array}{l}\text { Исследования без последовательного контроля референсным методом или исследования с референсным методом, } \\
\text { не являющимся независимым от исследуемого метода, или нерандомизированные сравнительные исследования, } \\
\text { в том числе когортные исследования }\end{array}$ \\
\hline 4 & Несравнительные исследования, описание клинического случая \\
\hline 5 & Имеется лишь обоснование механизма действия или мнение экспертов \\
\hline
\end{tabular}

\begin{tabular}{|c|c|}
\hline удД & Расшифровка \\
\hline 1 & Систематический обзор РКИ с применением метаанализа \\
\hline 2 & $\begin{array}{l}\text { Отдельные РКИ и систематические обзоры исследований любого дизайна, за исключением РКИ, } \\
\text { с применением метаанализа }\end{array}$ \\
\hline 3 & Нерандомизированные сравнительные исследования, в том числе когортные исследования \\
\hline 4 & $\begin{array}{l}\text { Несравнительные исследования, описание клинического случая или серии случаев, } \\
\text { исследования «случай-контроль» }\end{array}$ \\
\hline 5 & $\begin{array}{l}\text { Имеется лишь обоснование механизма действия вмешательства (доклинические исследования) } \\
\text { или мнение экспертов }\end{array}$ \\
\hline
\end{tabular}

Таблица А2.3. Шкала оценки УуР для методов профилактики, диагностики, лечения и реабилитации (профилактических, диагностических, лечебных, реабилитационных вмешательств)

Table A2.3. Scale for assessing the strength of recommendations for prevention, diagnosis, treatment and rehabilitation methods (prevention, diagnosis, treatment and rehabilitation interventions)

\begin{tabular}{|l|l|}
\hline Уур & Расшифровка \\
\hline A & $\begin{array}{l}\text { Сильная рекомендация [все рассматриваемые критерии эффективности (исходы) являются важными, } \\
\text { все исследования имеют высокое или удовлетворительное методологическое качество, } \\
\text { их выводы по интересующим исходам являются согласованными] }\end{array}$ \\
\hline В & $\begin{array}{l}\text { Условная рекомендация [не все рассматриваемые критерии эффективности (исходы) являются важными, } \\
\text { не все исследования имеют высокое или удовлетворительное методологическое качество и/или их выводы } \\
\text { по интересующим исходам не являются согласованными] }\end{array}$ \\
\hline C & $\begin{array}{l}\text { Слабая рекомендация [отсутствие доказательств надлежащего качества, все рассматриваемые критерии } \\
\text { эффективности (исходы) являются неважными, все исследования имеют низкое методологическое качество, } \\
\text { и их выводы по интересующим исходам не являются согласованными] }\end{array}$ \\
\hline
\end{tabular}


Рекомендации обсуждены и одобрены ведущими специалистами профильных федеральных центров РФ и практическими врачами. Проект клинических рекомендаций рассмотрен на совещаниях рабочей группы в 2017-2018 гг., на Форуме экспертов по вопросам диагностики и лечения злокачественных лимфопролиферативных заболеваний «Лимфорум», ежегодной Российской конференции с международным участием «Злокаче- ственные лимфомы», а также в рамках IV Конгресса гематологов России

Окончательная редакция. Для окончательной редакции и контроля качества рекомендации были повторно проанализированы членами авторского коллектива, которые пришли к заключению, что все существенные замечания и комментарии экспертов приняты во внимание, риск систематических ошибок при разработке сведен к минимуму.

\section{Приложение АЗ. Связанные документы}

\section{Приложение АЗ.1. Режимы лекарственного лечения ЛХ}

При проведении ХТ рекомендуется контролировать массу тела пациента и производить пересчет доз химиопрепаратов при изменении массы тела.

\subsection{1. Схемы 1-й линии терапии кЛХ}

\begin{tabular}{|c|c|c|c|}
\hline \multicolumn{4}{|l|}{ ABVD $[13,14,16]$} \\
\hline Препарат & $\begin{array}{c}\text { Стандартная } \\
\text { доза }\end{array}$ & Путь введения & Дни введения \\
\hline Доксорубицин & $25 \mathrm{Mr} / \mathrm{M}^{2}$ & $\begin{array}{l}\text { Внутривенно } \\
\text { капельно } \\
\text { или струйно }\end{array}$ & $\begin{array}{c}\text { 1, } 15 \text { (каждые } \\
14 \text { дней) }\end{array}$ \\
\hline Блеомицин ${ }^{* *}$ & $10 \mathrm{Mr} / \mathrm{M}^{2}$ & $\begin{array}{l}\text { Внутривенно } \\
\text { струйно }\end{array}$ & $\begin{array}{c}, 15 \text { (каждые } \\
14 \text { дней) }\end{array}$ \\
\hline Винбластин & $\begin{array}{c}6 \mathrm{mr} / \mathrm{M}^{2} \\
\text { (не более } 10 \mathrm{мг} \text { ) }\end{array}$ & $\begin{array}{l}\text { Внутривенно, } \\
\text { за 5-10 мин }\end{array}$ & $\begin{array}{c}\text { 1, } 15 \text { (каждые } \\
14 \text { дней) }\end{array}$ \\
\hline Дакарбазин ** & $375 \mathrm{Mr} / \mathrm{M}^{2}$ & $\begin{array}{c}\text { Внутривенно } \\
\text { капельно }\end{array}$ & $\begin{array}{c}\text { 1, } 15 \text { (каждые } \\
14 \text { дней) }\end{array}$ \\
\hline
\end{tabular}

\begin{tabular}{|c|c|c|c|}
\hline \multicolumn{4}{|c|}{ ВЕАСОРР-эскалированный $[4,15,17]$} \\
\hline Препарат & $\begin{array}{c}\text { Стандартная } \\
\text { доза }\end{array}$ & $\begin{array}{c}\text { Путь } \\
\text { введения }\end{array}$ & Дни введения \\
\hline Циклофооссрамид** & $1250 \mathrm{mr} / \mathrm{M}^{2}$ & $\begin{array}{c}\text { Внутривенно } \\
\text { капельно }\end{array}$ & 1 \\
\hline Доксорубицин ** & $35 \mathrm{Mr} / \mathrm{M}^{2}$ & $\begin{array}{c}\text { Внутривенно } \\
\text { капельно } \\
\text { или струйно }\end{array}$ & 1 \\
\hline Этопозид ** & $200 \mathrm{Mr} / \mathrm{M}^{2}$ & $\begin{array}{c}\text { Внутривенно } \\
\text { капельно }\end{array}$ & $1-3$ \\
\hline Прокарбазин ${ }^{\star *}$ & $100 \mathrm{Mr} / \mathrm{M}^{2}$ & Внутрь & $1-7$ \\
\hline Блеомицин ${ }^{* *}$ & $10 \mathrm{Mr} / \mathrm{M}^{2}$ & $\begin{array}{c}\text { Внутривенно } \\
\text { струйно }\end{array}$ & 8 \\
\hline Винкристин ${ }^{\star *}$ & $\begin{array}{c}1,4 \mathrm{мг} / \mathrm{M}^{2} \\
\text { (не более } 2 \mathrm{мг} \text { ) }\end{array}$ & $\begin{array}{c}\text { Внутривенно, } \\
\text { за 5-10 мин }\end{array}$ & 8 \\
\hline Преднизолон ** & $40 \mathrm{Mr} / \mathrm{M}^{2}$ & Внутрь & $1-14$ \\
\hline Г-КСФ & $\begin{array}{r}\text { Согласно инс } \\
\text { медицинскому }\end{array}$ & $\begin{array}{l}\text { трукциии по } \\
\text { применению }\end{array}$ & $\begin{array}{c}\text { С } 8 \text { до 12-го дня } \\
\text { или до } \\
\text { восстановления } \\
\text { лейкоцитов }\end{array}$ \\
\hline \multicolumn{4}{|c|}{$\begin{array}{l}\text { Лечение возобновляется на 22-й день. Накануне и с } 1 \text {-го дня цикла } \\
\text { рекомендуется увеличивать объем потребляемой жидкости до } 2 \text { л } \\
\text { в день. При большой опухолевой массе каждому пациенту } \\
\text { назначают аллопуринол“* в дозе } 300 \text { мг/сут и в первые } 3 \text { дня цикла } \\
\text { назначают гидратирующую терапию в объеме до } 3 \text { л/м² при строгом } \\
\text { контроле за диурезом и электролитными показателями [12] }\end{array}$} \\
\hline
\end{tabular}

\begin{tabular}{|c|c|c|c|}
\hline \multicolumn{4}{|l|}{ BEACOPP-14 [16, 21] } \\
\hline Препарат & $\begin{array}{c}\text { Стандартная } \\
\text { доза }\end{array}$ & $\begin{array}{c}\text { Путь } \\
\text { введения }\end{array}$ & Дни введения \\
\hline Циклосроссрамид** & $650 \mathrm{Mr} / \mathrm{M}^{2}$ & $\begin{array}{c}\text { Внутривенно } \\
\text { капельно }\end{array}$ & 1 \\
\hline Доксорубицин ** & $25 \mathrm{Mr} / \mathrm{M}^{2}$ & $\begin{array}{c}\text { Внутривенно } \\
\text { капельно } \\
\text { или струйно }\end{array}$ & 1 \\
\hline Этопозид ** & $100 \mathrm{Mr} / \mathrm{M}^{2}$ & $\begin{array}{c}\text { Внутривенно } \\
\text { капельно }\end{array}$ & $1-3$ \\
\hline Прокарбазин ${ }^{\star *}$ & $100 \mathrm{Mr} / \mathrm{M}^{2}$ & Внутрь & $1-7$ \\
\hline
\end{tabular}

\begin{tabular}{|c|c|c|c|}
\hline \multicolumn{4}{|c|}{ ВЕАСОРР-14 [16, 21]. Продолжение } \\
\hline Препарат & $\begin{array}{c}\text { Стандартная } \\
\text { доза }\end{array}$ & $\begin{array}{c}\text { Путь } \\
\text { введения }\end{array}$ & Дни введения \\
\hline Блеомицин ${ }^{\star \star}$ & $10 \mathrm{Mr} / \mathrm{M}^{2}$ & $\begin{array}{c}\text { Внутривенно } \\
\text { струйно }\end{array}$ & 8 \\
\hline Винкристин ** & 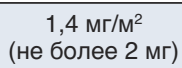 & $\begin{array}{c}\text { Внутривенно, } \\
\text { за 5-10 мин }\end{array}$ & 8 \\
\hline $\begin{array}{l}\text { Преднизолон }{ }^{* *} \\
\text { или }\end{array}$ & $40 \mathrm{Mr} / \mathrm{M}^{2}$ & Внутривенно & $\begin{array}{c}1-14 \\
\text { Отмена } \\
\text { преднизолона*夫 } \\
\text { в } 1 \text { день } \\
\text { на 8-й день } \\
\text { цикла. } \\
\text { При } \\
\text { возникновении } \\
\text { синдрома } \\
\text { отмены - } \\
\text { в 3 дня } \\
\text { 1-3-й дни }\end{array}$ \\
\hline Г-КСФ & $\begin{array}{r}\text { Согласно ин } \\
\text { медицинском }\end{array}$ & $\begin{array}{l}\text { трукции по } \\
\text { применению }\end{array}$ & $\begin{array}{l}\text { 9-13-й дни } \\
\text { в плановом } \\
\text { порядке } \\
\text { независимо } \\
\text { от количества } \\
\text { лейкоцитов }\end{array}$ \\
\hline \multicolumn{4}{|c|}{ 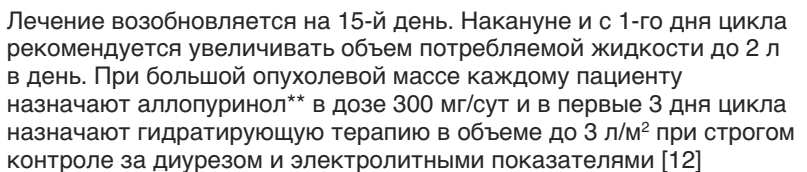 } \\
\hline
\end{tabular}

\begin{tabular}{|c|c|c|c|}
\hline \multicolumn{4}{|l|}{ EACOPP-14 [22] } \\
\hline Препарат & $\begin{array}{c}\text { Стандартная } \\
\text { доза }\end{array}$ & $\begin{array}{c}\text { Путь } \\
\text { введения }\end{array}$ & Дни введения \\
\hline Циклофроссрамид ** & $650 \mathrm{Mr} / \mathrm{M}^{2}$ & $\begin{array}{c}\text { Внутривенно } \\
\text { капельно }\end{array}$ & 1 \\
\hline Доксорубицин ${ }^{\star *}$ & $50 \mathrm{Mr} / \mathrm{M}^{2}$ & $\begin{array}{c}\text { Внутривенно } \\
\text { капельно } \\
\text { или струйно }\end{array}$ & 1 \\
\hline Этопозид ** & $100 \mathrm{Mr} / \mathrm{M}^{2}$ & $\begin{array}{c}\text { Внутривенно } \\
\text { капельно }\end{array}$ & $1-3$ \\
\hline $\begin{array}{l}\text { Прокарбазин } \\
\text { или } \\
\text { Дакарбазин }\end{array}$ & $\begin{array}{l}100 \mathrm{Mr} / \mathrm{M}^{2} \\
375 \mathrm{Mr} / \mathrm{M}^{2}\end{array}$ & $\begin{array}{c}\text { Внутрь } \\
\text { Внутривенно }\end{array}$ & $\begin{array}{c}1-7 \\
1\end{array}$ \\
\hline Винкристин $^{\star *}$ & $\begin{array}{c}1,4 \mathrm{мг} / \mathrm{M}^{2} \\
\text { (не более } 2 \mathrm{мг})\end{array}$ & $\begin{array}{c}\text { Внутривенно, } \\
\text { за 5-10 мин }\end{array}$ & 8 \\
\hline $\begin{array}{l}\text { Преднизолон }{ }^{* *} \\
\text { или }\end{array}$ & $40 \mathrm{Mr} / \mathrm{M}^{2}$ & Внутривенно & $\begin{array}{c}1-7 \\
\text { Отмена } \\
\text { преднизолона** } \\
\text { в } 1 \text { день } \\
\text { на 8-й день } \\
\text { цикла. } \\
\text { При } \\
\text { возникновении } \\
\text { синдрома } \\
\text { отмены - } \\
\text { в 3 дня } \\
\text { 1-3-й дни }\end{array}$ \\
\hline
\end{tabular}


JOURNAL OF MODERN ONCOLOGY. 2020; 22 (2): 6-33.

\begin{tabular}{|c|c|c|c|}
\hline \multicolumn{4}{|c|}{ ЕАСОРР-14 [22]. Продолжение } \\
\hline Препарат & $\begin{array}{c}\text { Стандартная } \\
\text { доза }\end{array}$ & $\begin{array}{c}\text { Путь } \\
\text { введения }\end{array}$ & Дни введения \\
\hline Г-КСФ & \multicolumn{2}{|c|}{$\begin{array}{c}\text { Согласно инструкции по } \\
\text { медицинскому применению }\end{array}$} & $\begin{array}{c}\text { 9-13-й дни } \\
\text { в плановом } \\
\text { порядке } \\
\text { независимо } \\
\text { от количества } \\
\text { лейкоцитов }\end{array}$ \\
\hline
\end{tabular}

Лечение возобновляется на 15-й день. Накануне и с первого дня цикла рекомендуется увеличивать объем потребляемой жидкости до 2 л в день. При большой опухолевой массе каждому пациенту назначают аллопуринол ${ }^{\star \star}$ в дозе 300 мг/сут и в первые 3 дня цикла назначают гидратирующую терапию в объеме до 3 л/ $\mathrm{M}^{2}$ при строгом контроле за диурезом и электролитными показателями [12]

\begin{tabular}{|c|c|c|c|}
\hline \multicolumn{4}{|l|}{ BV-AVD [30] } \\
\hline Препарат & $\begin{array}{c}\text { Стандартная } \\
\text { доза }\end{array}$ & $\begin{array}{c}\text { Путь } \\
\text { введения }\end{array}$ & Дни введения \\
\hline $\begin{array}{l}\text { Брентуксимаб } \\
\text { ведотин }^{\star *}\end{array}$ & 1,2 мг/кг & \begin{tabular}{|c|} 
Внутривенно \\
инфуузия \\
30 мин через \\
1 ч после \\
завершения \\
введения \\
AVD \\
\end{tabular} & 1,15 \\
\hline Доксорубицин ** & $25 \mathrm{Mr} / \mathrm{M}^{2}$ & \begin{tabular}{|c|} 
Внутривенно \\
капельно \\
или струйно
\end{tabular} & 1,15 \\
\hline Винбластин ** & $\begin{array}{c}6 \text { мг/M² (не } \\
\text { более } 10 \text { мг) }\end{array}$ & \begin{tabular}{|c|} 
Внутривенно, \\
за 5-10 мин
\end{tabular} & 1,15 \\
\hline Дакарбазин ** & $375 \mathrm{Mr} / \mathrm{M}^{2}$ & $\begin{array}{c}\text { Внутривенно } \\
\text { капельно }\end{array}$ & 1,15 \\
\hline \multicolumn{4}{|c|}{$\begin{array}{l}\text { Лечение возобновляется на 29-й день. Накануне и с первого дня } \\
\text { цикла рекомендуется увеличивать объем потребляемой жидкости } \\
\text { до } 2 \text { л в день. При большой опухолевой массе каждому пациенту } \\
\text { назначают аллопуринол }{ }^{\star *} \text { в дозе } 300 \text { мг/сут и в первые } 3 \text { дня цикла } \\
\text { назначают гидратирующую терапию в объеме до } 3 \text { л/м² при строгом } \\
\text { контроле за диурезом и электролитными показателями [12]. } \\
\text { Первичная профилактика Г-КСФ рекомендована всем пациентам } \\
\text { независимо от их возраста, начиная с первой дозы, начиная } \\
\text { в первые } 4 \text { дня после введения химиопрепаратов, но не позднее } \\
\text { 5-го дня [30] }\end{array}$} \\
\hline
\end{tabular}

\subsection{2. Схемы терапии ЛХ у пациентов до 18 лет}

\begin{tabular}{|c|c|c|c|}
\hline \multicolumn{4}{|l|}{ OEPA [31] } \\
\hline Препарат & $\begin{array}{c}\text { Стандартная } \\
\text { доза }\end{array}$ & $\begin{array}{c}\text { Путь } \\
\text { введения }\end{array}$ & Дни введения \\
\hline Преднизолон ** & $\begin{array}{l}60 \text { мг/м²/сут } \\
\text { на } 3 \text { приема }\end{array}$ & Внутрь & $1-15$ \\
\hline Винкристин $^{\star *}$ & $\begin{array}{c}1,5 \mathrm{мг} / \mathrm{M}^{2} \\
\text { (не более } 2 \mathrm{mг} \text { ) }\end{array}$ & $\begin{array}{c}\text { Внутривенно } \\
\text { струйно }\end{array}$ & $1,8,15$ \\
\hline Доксорубицин ** & $40 \mathrm{Mr} / \mathrm{M}^{2}$ & $\begin{array}{c}\text { Внутривенно } \\
\text { в течение } \\
1-6 \text { ч }\end{array}$ & 1,15 \\
\hline Этопозид ** & $125 \mathrm{Mr} / \mathrm{M}^{2}$ & $\begin{array}{c}\text { Внутривенно } \\
\text { в течение } \\
1-2 \text { ч }\end{array}$ & $2-6$ \\
\hline
\end{tabular}

\begin{tabular}{|c|c|c|c|}
\hline \multicolumn{4}{|l|}{ COPDAC [31] } \\
\hline Препарат & $\begin{array}{l}\text { Стандартная } \\
\text { доза }\end{array}$ & $\begin{array}{c}\text { Путь } \\
\text { введения }\end{array}$ & Дни введения \\
\hline Преднизолон ${ }^{* *}$ & $\begin{array}{c}40 \text { мг/м²/сут p.o. } \\
\text { на } 3 \text { приема }\end{array}$ & Внутрь & $1-15$ \\
\hline Винкристин ** & $\begin{array}{c}1,5 \mathrm{mг} / \mathrm{M}^{2} \\
\text { (макс. } 2 \mathrm{Mг} \text { ) }\end{array}$ & $\begin{array}{c}\text { Внутривенно } \\
\text { струйно }\end{array}$ & 1,8 \\
\hline Дакарбазин ** & $250 \mathrm{Mr} / \mathrm{M}^{2}$ & $\begin{array}{c}\text { Внутривенно } \\
\text { в течение } \\
30 \text { мин }\end{array}$ & $1,2,3$ \\
\hline Циклофросфрамид ** & $500 \mathrm{Mr} / \mathrm{M}^{2}$ & $\begin{array}{c}\text { Внутривенно } \\
\text { в течение } \\
14\end{array}$ & 1,8 \\
\hline \multicolumn{4}{|c|}{ Лечение возобновляется на 29-й день } \\
\hline
\end{tabular}

\subsection{3. Схемы терапии пожилых пациентов с ЛХ}

\begin{tabular}{|c|c|c|c|}
\hline \multicolumn{4}{|l|}{ ChIVPP [74] } \\
\hline Препарат & $\begin{array}{c}\text { Стандартная } \\
\text { доза }\end{array}$ & $\begin{array}{c}\text { Путь } \\
\text { введения }\end{array}$ & Дни введения \\
\hline Хлорамбуцил ** & $6 \mathrm{Mr} / \mathrm{M}^{2}$ & Внутривенно & $1-14$ \\
\hline Прокарбазин *夫 & $100 \mathrm{mr} / \mathrm{M}^{2}$ & Внутривенно & $1-14$ \\
\hline Винбластин ${ }^{\star *}$ & $6 \mathrm{mr} / \mathrm{M}^{2}$ & Внутривенно & 1,8 \\
\hline Преднилозон ** & $40 \mathrm{Mr} / \mathrm{M}^{2}$ & Внутрь & $1-14$ \\
\hline
\end{tabular}

\begin{tabular}{|c|c|c|c|}
\hline \multicolumn{4}{|l|}{ CVPP [75] } \\
\hline Препарат & $\begin{array}{c}\text { Стандартная } \\
\text { доза }\end{array}$ & $\begin{array}{c}\text { Путь } \\
\text { введения }\end{array}$ & Дни введения \\
\hline Циклофосфрамид & $600 \mathrm{Mr} / \mathrm{M}^{2}$ & Внутривенно & 1,8 \\
\hline Прокарбазин ${ }^{\star *}$ & $100 \mathrm{mr} / \mathrm{M}^{2}$ & Внутрь & $1-14$ \\
\hline Винбластин ** & $6 \mathrm{Mr} / \mathrm{M}^{2}$ & Внутривенно & 1,8 \\
\hline Преднилозон ** & $40 \mathrm{mr} / \mathrm{M}^{2}$ & Внутрь & $1-14$ \\
\hline
\end{tabular}

\begin{tabular}{|c|c|c|c|}
\hline \multicolumn{4}{|l|}{ COPP [76] } \\
\hline Препарат & $\begin{array}{c}\text { Стандартная } \\
\text { доза }\end{array}$ & $\begin{array}{c}\text { Путь } \\
\text { введения }\end{array}$ & Дни введения \\
\hline Циклофросфрамид ** & $600 \mathrm{Mr} / \mathrm{M}^{2}$ & Внутривенно & 1,8 \\
\hline Прокарбазин ** & $100 \mathrm{mr} / \mathrm{M}^{2}$ & Внутрь & $1-14$ \\
\hline Винкристин & $\begin{array}{c}1,4 \mathrm{Mr} / \mathrm{M}^{2} \\
\text { (не более } 2 \mathrm{мг})\end{array}$ & $\begin{array}{c}\text { Внутривенно, } \\
\text { за 5-10 мин }\end{array}$ & 1,8 \\
\hline Преднилозон ** & $40 \mathrm{mr} / \mathrm{M}^{2}$ & Внутрь & $1-14$ \\
\hline
\end{tabular}

\begin{tabular}{|c|c|c|c|}
\hline \multicolumn{4}{|l|}{ IVDG [38] } \\
\hline Препарат & $\begin{array}{c}\text { Стандартная } \\
\text { доза }\end{array}$ & $\begin{array}{c}\text { Путь } \\
\text { введения }\end{array}$ & Дни введения \\
\hline Идарубицин ${ }^{\star *}$ & $5 \mathrm{mr} / \mathrm{M}^{2}$ & Внутривенно & 1,15 \\
\hline Винбластин ** & $5 \mathrm{Mr} / \mathrm{M}^{2}$ & Внутривенно & 1,15 \\
\hline Дакарбазин ${ }^{\star *}$ & $375 \mathrm{Mr} / \mathrm{M}^{2}$ & Внутривенно & 1,15 \\
\hline Гемцитабин ${ }^{\star *}$ & $800 \mathrm{Mr} / \mathrm{M}^{2}$ & Внутривенно & 1,15 \\
\hline \multicolumn{4}{|c|}{ 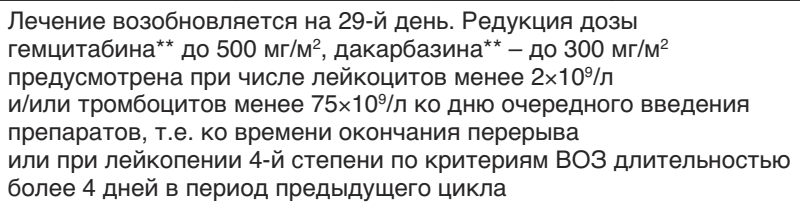 } \\
\hline
\end{tabular}

\begin{tabular}{|c|c|c|c|}
\hline \multicolumn{4}{|l|}{ VEPEMB [77] } \\
\hline Препарат & $\begin{array}{c}\text { Стандартная } \\
\text { доза }\end{array}$ & $\begin{array}{c}\text { Путь } \\
\text { введения }\end{array}$ & Дни введения \\
\hline Винбластин ** & $6 \mathrm{Mr} / \mathrm{M}^{2}$ & Внутривенно & 1 \\
\hline Циклофоссфамид ** & $500 \mathrm{Mr} / \mathrm{M}^{2}$ & Внутривенно & 1 \\
\hline Прокарбазин ** & $100 \mathrm{Mr} / \mathrm{M}^{2}$ & Внутрь & $1-5$ \\
\hline Преднизолон ** & $30 \mathrm{Mr} / \mathrm{M}^{2}$ & Внутрь & $1-5$ \\
\hline Этопозид ${ }^{\star \star}$ & $60 \mathrm{Mr} / \mathrm{M}^{2}$ & Внутрь & $15-19$ \\
\hline Митоксантрон ${ }^{\star *}$ & $6 \mathrm{Mr} / \mathrm{M}^{2}$ & Внутривенно & 15 \\
\hline Блеомицин ${ }^{\star *}$ & $10 \mathrm{Mr} / \mathrm{M}^{2}$ & Внутривенно & 15 \\
\hline \multicolumn{4}{|c|}{ Лечение возобновляется на 29-й день } \\
\hline
\end{tabular}

\begin{tabular}{|c|c|c|c|}
\hline \multicolumn{4}{|l|}{ CVP [78] } \\
\hline Препарат & $\begin{array}{c}\text { Стандартная } \\
\text { доза }\end{array}$ & $\begin{array}{c}\text { Путь } \\
\text { введения }\end{array}$ & Дни введения \\
\hline Циклосросфрамид ** & $1000 \mathrm{mr} / \mathrm{M}^{2}$ & Внутривенно & 1 \\
\hline Винбластин ${ }^{\star *}$ & $6 \mathrm{Mr} / \mathrm{M}^{2}$ & Внутривенно & 1 \\
\hline Преднизолон ${ }^{\star *}$ & $40 \mathrm{Mr} / \mathrm{M}^{2}$ & Внутрь & $1-5$ \\
\hline
\end{tabular}


КЛИНИЧЕСКАЯ ОНКОЛОГИЯ / CLINICAL ONCOLOGY

\subsection{4. Схемы 2-й линии терапии ЛХ}

\begin{tabular}{|c|c|c|c|}
\hline \multicolumn{4}{|l|}{ IGEV [79] } \\
\hline Препарат & $\begin{array}{c}\text { Стандартная } \\
\text { доза }\end{array}$ & $\begin{array}{c}\text { Путь } \\
\text { введения }\end{array}$ & Дни введения \\
\hline Преднизолон ${ }^{\star *}$ & $100 \mathrm{мг}$ & Внутрь & $1-4$ \\
\hline Иоросфрамид ** & $2000 \mathrm{Mr} / \mathrm{M}^{2}$ & $\begin{array}{c}\text { Внутривенно } \\
\text { капельно }\end{array}$ & $1-4$ \\
\hline Винорелбин ${ }^{\star *}$ & $20 \mathrm{Mr} / \mathrm{M}^{2}$ & Внутривенно & 1 \\
\hline Гемцитабин ** & $800 \mathrm{Mr} / \mathrm{M}^{2}$ & $\begin{array}{c}\text { Внутривенно } \\
\text { капельно }\end{array}$ & 1,4 \\
\hline
\end{tabular}

\begin{tabular}{|c|c|c|c|}
\hline \multicolumn{4}{|l|}{ DHAP [80] } \\
\hline Препарат & $\begin{array}{c}\text { Стандартная } \\
\text { доза }\end{array}$ & $\begin{array}{c}\text { Путь } \\
\text { введения }\end{array}$ & Дни введения \\
\hline Дексаметазон ${ }^{\star *}$ & $40 \mathrm{Mr}$ & Внутривенно & $1-4$ \\
\hline Цисплатин ${ }^{\star \star \# ~}$ & $100 \mathrm{Mr} / \mathrm{M}^{2}$ & $\begin{array}{c}\text { Внутривенно } \\
\text { капельно } \\
\text { 24-часовая } \\
\text { инфуузия }\end{array}$ & 1 \\
\hline Цитарабин ${ }^{\star *}$ & $2 \mathrm{Mr} / \mathrm{M}^{2}$ & $\begin{array}{c}\text { Внутривенно } \\
\text { капельно } \\
2 \text { раза в день }\end{array}$ & 2 \\
\hline
\end{tabular}

\begin{tabular}{|c|c|c|c|}
\hline \multicolumn{4}{|l|}{ ESHAP [81] } \\
\hline Препарат & $\begin{array}{c}\text { Стандартная } \\
\text { доза }\end{array}$ & $\begin{array}{c}\text { Путь } \\
\text { введения }\end{array}$ & Дни введения \\
\hline Этопозид ** & $40 \mathrm{Mr} / \mathrm{M}^{2}$ & $\begin{array}{c}\text { Внутривенно } \\
\text { капельно }\end{array}$ & $1-4$ \\
\hline $\begin{array}{l}\text { Метил- } \\
\text { преднизолон }{ }^{\star *}\end{array}$ & $500 \mathrm{Mr}$ & $\begin{array}{c}\text { Внутривенно } \\
\text { капельно }\end{array}$ & $1-4$ \\
\hline Цисплатин ${ }^{\star \star \# ~}$ & $25 \mathrm{mr} / \mathrm{M}^{2} /$ сут & $\begin{array}{c}\text { Внутривенно } \\
\text { непрерывная } \\
\text { инфуузия }\end{array}$ & $1-4$ \\
\hline Цитарабин ** & $2000 \mathrm{Mr} / \mathrm{M}^{2}$ & $\begin{array}{c}\text { Внутривенно } \\
\text { капельно }\end{array}$ & 5 \\
\hline
\end{tabular}

\begin{tabular}{|c|c|c|c|}
\hline \multicolumn{4}{|l|}{ ICE [82] } \\
\hline Препарат & $\begin{array}{c}\text { Стандартная } \\
\text { доза }\end{array}$ & $\begin{array}{c}\text { Путь } \\
\text { введения }\end{array}$ & Дни введения \\
\hline Этопозид ${ }^{\star \star}$ & $100 \mathrm{Mr} / \mathrm{M}^{2}$ & $\begin{array}{c}\text { Внутривенно } \\
\text { капельно }\end{array}$ & $1-3$ \\
\hline Ифоосфамид ${ }^{\star *}$ & $5000 \mathrm{Mr} / \mathrm{M}^{2}$ & $\begin{array}{c}\text { Внутривенно } \\
\text { 24-часовая } \\
\text { инфрузия }\end{array}$ & 1 \\
\hline Карбоплатин ${ }^{\star \star \#}$ & AUC 5 & $\begin{array}{c}\text { Внутривенно } \\
\text { капельно }\end{array}$ & 1 \\
\hline
\end{tabular}

\begin{tabular}{|l|c|c|c|}
\hline GDP [81] & $\begin{array}{c}\text { Стандартная } \\
\text { доза }\end{array}$ & $\begin{array}{c}\text { Путь } \\
\text { введения }\end{array}$ & Дни введения \\
\hline Препарат & $75 \mathrm{mг} / \mathrm{M}^{2}$ & $\begin{array}{c}\text { Внутривенно } \\
\text { капельно }\end{array}$ & 1 \\
\hline Цисплатин $^{\star \star *}$ & $1000 \mathrm{mг} / \mathrm{M}^{2}$ & $\begin{array}{c}\text { Внутривенно } \\
\text { капельно }\end{array}$ & 1,8 \\
\hline Гемцитабин $^{* *}$ & $40 \mathrm{mг}$ & Внутрь & $1-4$ \\
\hline Дексаметазон $^{* *}$ & & & \\
\hline
\end{tabular}

\begin{tabular}{|c|c|c|c|}
\hline \multicolumn{4}{|l|}{ GemOX [83] } \\
\hline Препарат & $\begin{array}{c}\text { Стандартная } \\
\text { доза }\end{array}$ & $\begin{array}{c}\text { Путь } \\
\text { введения }\end{array}$ & Дни введения \\
\hline Гемцитабин ** & $1000 \mathrm{Mr} / \mathrm{M}^{2}$ & $\begin{array}{c}\text { Внутривенно } \\
\text { капельно }\end{array}$ & 1 \\
\hline Оксалиплатин ${ }^{\star \star \#}$ & $100 \mathrm{Mr} / \mathrm{M}^{2}$ & $\begin{array}{c}\text { Внутривенно } \\
\text { капельно }\end{array}$ & 1 \\
\hline
\end{tabular}

\begin{tabular}{|c|c|c|c|}
\hline \multicolumn{4}{|l|}{ IEP [84] } \\
\hline Препарат & $\begin{array}{c}\text { Стандартная } \\
\text { доза }\end{array}$ & $\begin{array}{c}\text { Путь } \\
\text { введения }\end{array}$ & Дни введения \\
\hline Ифоссрамид & $2000 \mathrm{Mr} / \mathrm{M}^{2}$ & $\begin{array}{c}\text { Внутривенно } \\
\text { суточной } \\
\text { инфузией } \\
\text { (с месной) }\end{array}$ & $1-5$ \\
\hline Этопозид & $125 \mathrm{Mr} / \mathrm{M}^{2}$ & $\begin{array}{l}\text { Внутривенно } \\
\text { В течение } 2 \text { ч }\end{array}$ & $1-5$ \\
\hline Преднизолон ${ }^{\star *}$ & $100 \mathrm{Mr} / \mathrm{M}^{2}$ & $\begin{array}{c}\text { Внутривенно } \\
\text { или внутрь }\end{array}$ & $1-5$ \\
\hline
\end{tabular}

\begin{tabular}{|c|c|c|c|}
\hline \multicolumn{4}{|c|}{ Монотерапия брентуксимабом ведотином** [44] } \\
\hline Препарат & $\begin{array}{c}\text { Стандартная } \\
\text { доза }\end{array}$ & $\begin{array}{c}\text { Путь } \\
\text { введения }\end{array}$ & Дни введения \\
\hline $\begin{array}{l}\text { Брентуксимаб } \\
\text { ведотин }^{\star *}\end{array}$ & 1,8 $\mathrm{Mr} / \mathrm{Kr}$ & $\begin{array}{c}\text { Внутривенно } \\
\text { В течение } \\
30 \text { мин }\end{array}$ & 1 \\
\hline \multicolumn{4}{|c|}{$\begin{array}{l}\text { Введения повторяются каждые } 3 \text { нед. Если масса тела пациента } \\
\text { превышает } 100 \text { кг, при расчете дозы следует использовать значение } \\
\text { массы } 100 \text { кг. У пациентов, не кандидатов на ВДХТ с аутоТГСК, } \\
\text { при достижении стабилизации или при положительной динамике } \\
\text { заболевания лечение продолжают до 16, но не менее } 8 \text { циклов, } \\
\text { при отсутствии прогрессирования и с оценкой чувствительности } \\
\text { каждые } 4 \text { введения. Полная длительность лечения составляет } \\
\text { приблизительно } 1 \text { год }\end{array}$} \\
\hline
\end{tabular}

\begin{tabular}{|l|c|c|c|}
\hline Монотерапия ниволумабом** [45, 85] \\
\hline Препарат & $\begin{array}{c}\text { Стандартная } \\
\text { доза }\end{array}$ & $\begin{array}{c}\text { Путь } \\
\text { введения }\end{array}$ & Дни введения \\
\hline Ниволумаб & $\begin{array}{c}3 \text { мг/кг } \\
\text { или } 240 \text { мг } \\
\text { независимо } \\
\text { от массы тела } \\
\text { или 480 мг } \\
\text { независимо } \\
\text { от массы тела }\end{array}$ & $\begin{array}{c}\text { Внутривенно } \\
\text { в течение } \\
60 \text { мин }\end{array}$ & 1 \\
\hline $\begin{array}{l}\text { Лечение возобновляется на 15-й день (для дозы 3 мг/кг или 240 мг) } \\
\text { или на 29-й день (для дозы 480 мг) }\end{array}$ \\
\hline
\end{tabular}

\begin{tabular}{|l|c|c|c|}
\hline \multicolumn{3}{|l|}{ Монотерапия пембролизумабом [46] } \\
\hline Препарат & $\begin{array}{c}\text { Стандартная } \\
\text { доза }\end{array}$ & $\begin{array}{c}\text { Путь } \\
\text { введения }\end{array}$ & Дни введения \\
\hline Пембролизумаб** & 200 мг & $\begin{array}{c}\text { Внутривенно } \\
\text { в течение } \\
\text { Зо мин }\end{array}$ & 1 \\
\hline Лечение возобновляется на 22-й день \\
\hline
\end{tabular}

\subsection{5. Схемы терапии пациентов с НлплХ}

\begin{tabular}{|c|c|c|c|}
\hline \multicolumn{4}{|l|}{ R-CHOP [56] } \\
\hline Препарат & $\begin{array}{c}\text { Стандартная } \\
\text { доза }\end{array}$ & $\begin{array}{c}\text { Путь } \\
\text { введения }\end{array}$ & Дни введения \\
\hline Ритуксимаб*夫\# & $375 \mathrm{Mr} / \mathrm{M}^{2}$ & $\begin{array}{c}\text { Внутривенно } \\
\text { капельно }\end{array}$ & 0 или 1 \\
\hline Доксорубицин ** & $50 \mathrm{mr} / \mathrm{M}^{2}$ & $\begin{array}{c}\text { Внутривенно } \\
\text { капельно }\end{array}$ & 1 \\
\hline Циклофоссфамид ** & $750 \mathrm{Mr} / \mathrm{M}^{2}$ & $\begin{array}{c}\text { Внутривенно } \\
\text { капельно }\end{array}$ & 1 \\
\hline Винкристин ${ }^{\star *}$ & $\begin{array}{c}1,4 \mathrm{mr} / \mathrm{M}^{2} \\
\text { (не более } 2 \mathrm{mr} \text { ) }\end{array}$ & $\begin{array}{c}\text { Внутривенно, } \\
\text { за 5-10 мин }\end{array}$ & 1 \\
\hline Преднилозон ${ }^{\star *}$ & $100 \mathrm{Mr}$ & Внутрь & $1-5$ \\
\hline
\end{tabular}

\begin{tabular}{|c|c|c|c|}
\hline \multicolumn{4}{|c|}{ R-CVP (дозировки для детей и подростков с НЛХЛП) [55] } \\
\hline Препарат & $\begin{array}{c}\text { Стандартная } \\
\text { доза }\end{array}$ & $\begin{array}{c}\text { Путь } \\
\text { введения }\end{array}$ & Дни введения \\
\hline Ритуксимаб*夫\# & $375 \mathrm{Mr} / \mathrm{M}^{2}$ & $\begin{array}{c}\text { Внутривенно } \\
\text { капельно }\end{array}$ & 0 или 1 \\
\hline Циклофооссрамид & $500 \mathrm{mr} / \mathrm{M}^{2}$ & Внутривенно & 1 \\
\hline Винбластин ${ }^{\star \star}$ & $6 \mathrm{Mr} / \mathrm{M}^{2}$ & Внутривенно & 1,8 \\
\hline Преднизолон ${ }^{* *}$ & $40 \mathrm{Mr} / \mathrm{M}^{2}$ & Внутрь & $1-8$ \\
\hline \multicolumn{4}{|c|}{ Лечение возобновляется на 22-й ден } \\
\hline
\end{tabular}




\subsection{6. Режимы кондиционирования при аутоТГСК}

\begin{tabular}{|c|c|c|c|}
\hline \multicolumn{4}{|l|}{ BEAM [86] } \\
\hline Препарат & $\begin{array}{c}\text { Стандартная } \\
\text { доза }\end{array}$ & $\begin{array}{c}\text { Путь } \\
\text { введения }\end{array}$ & Дни введения \\
\hline Кармустин $^{\star *}$ & $300 \mathrm{Mr} / \mathrm{M}^{2}$ & $\begin{array}{c}\text { Внутривенно } \\
\text { капельно }\end{array}$ & -6 \\
\hline Цитарабин ** & $\begin{array}{c}100 \mathrm{mг} / \mathrm{M}^{2} \\
\text { каждые } 12 \text { ч }\end{array}$ & $\begin{array}{c}\text { Внутривенно } \\
\text { капельно }\end{array}$ & $-5--2$ \\
\hline Этопозид & $100 \mathrm{Mr} / \mathrm{M}^{2}$ & $\begin{array}{c}\text { Внутривенно } \\
\text { капельно }\end{array}$ & $-5--2$ \\
\hline Мелфралан ${ }^{\star \star}$ & $140 \mathrm{Mr} / \mathrm{M}^{2}$ & $\begin{array}{c}\text { Внутривенно } \\
\text { капельно }\end{array}$ & -1 \\
\hline
\end{tabular}

\begin{tabular}{|c|c|c|c|}
\hline \multicolumn{4}{|l|}{ CBV [86] } \\
\hline Препарат & $\begin{array}{c}\text { Стандартная } \\
\text { доза }\end{array}$ & $\begin{array}{c}\text { Путь } \\
\text { введения }\end{array}$ & Дни введения \\
\hline Кармустин ${ }^{* *}$ & $600 \mathrm{Mr} / \mathrm{M}^{2}$ & $\begin{array}{c}\text { Внутривенно } \\
\text { капельно }\end{array}$ & -3 \\
\hline Этопозид & $400 \mathrm{mr} / \mathrm{M}^{2}$ & $\begin{array}{c}\text { Внутривенно } \\
\text { капельно }\end{array}$ & $-7--5$ \\
\hline Циклофроссрамид ** & $1800 \mathrm{Mr} / \mathrm{M}^{2}$ & $\begin{array}{l}\text { Внутривенно } \\
\text { капельно }\end{array}$ & $-7--4$ \\
\hline
\end{tabular}

\section{Приложение А3.2. Рекомендации по редукции доз или увеличению промежутков при проведении миелосупрессивной цитостатической терапии}

Лечение следует проводить в полных дозах в соответствии со схемой, если в день введения химиопрепаратов уровень нейтрофилов более $1 \times 10^{9}$ /л и тромбоцитов более $100 \times 10^{9}$, но только в том случае, если пик падения уже пройден.

Если необходимый уровень нейтрофилов не достигается к плановому дню введения химиопрепаратов (15-й день от начала предыдущего цикла для схем ВЕАСОРР-14, ЕАСОРР14 и BV-AVD и 21-й день для схемы BEACOPР-эскалированный), введение Г-КСФ продолжается в прежних дозах до достижения уровня нейтрофилов более $1 \times 10^{9}$ при ежедневном контроле анализов крови, далее исследование крови повторяется через день. Лечение возобновляется при достижении вышеуказанных параметров.

В том случае, если показатели крови восстанавливаются в течение последующих 14 дней, следующий цикл проводится в полных дозах.
В случае, если показатели крови не восстанавливаются дольше дополнительных 14 дней, а также в случае повторной отсрочки курса вследствие миелотоксичности более 10 дней проводится снижение доз препаратов до 75\% от исходной дозы (кроме доз винкристина, блеомицина и преднизолона).

Если к плановому дню введения химиопрепаратов необходимый уровень тромбоцитов не достигается, в дальнейшем исследование крови повторяется на 3, 7, 10 и 14-й дни; лечение возобновляется при достижении вышеуказанных параметров. Если показатели крови восстанавливаются в течение дополнительных 14 дней, цикл проводится в полных дозах. В случае, если показатели крови не восстанавливаются дольше дополнительных 14 дней, в следующем цикле производится редукция доз по той же схеме, как и при длительной нейтропении.

\section{Приложение Б. Алгоритмы ведения пациента}

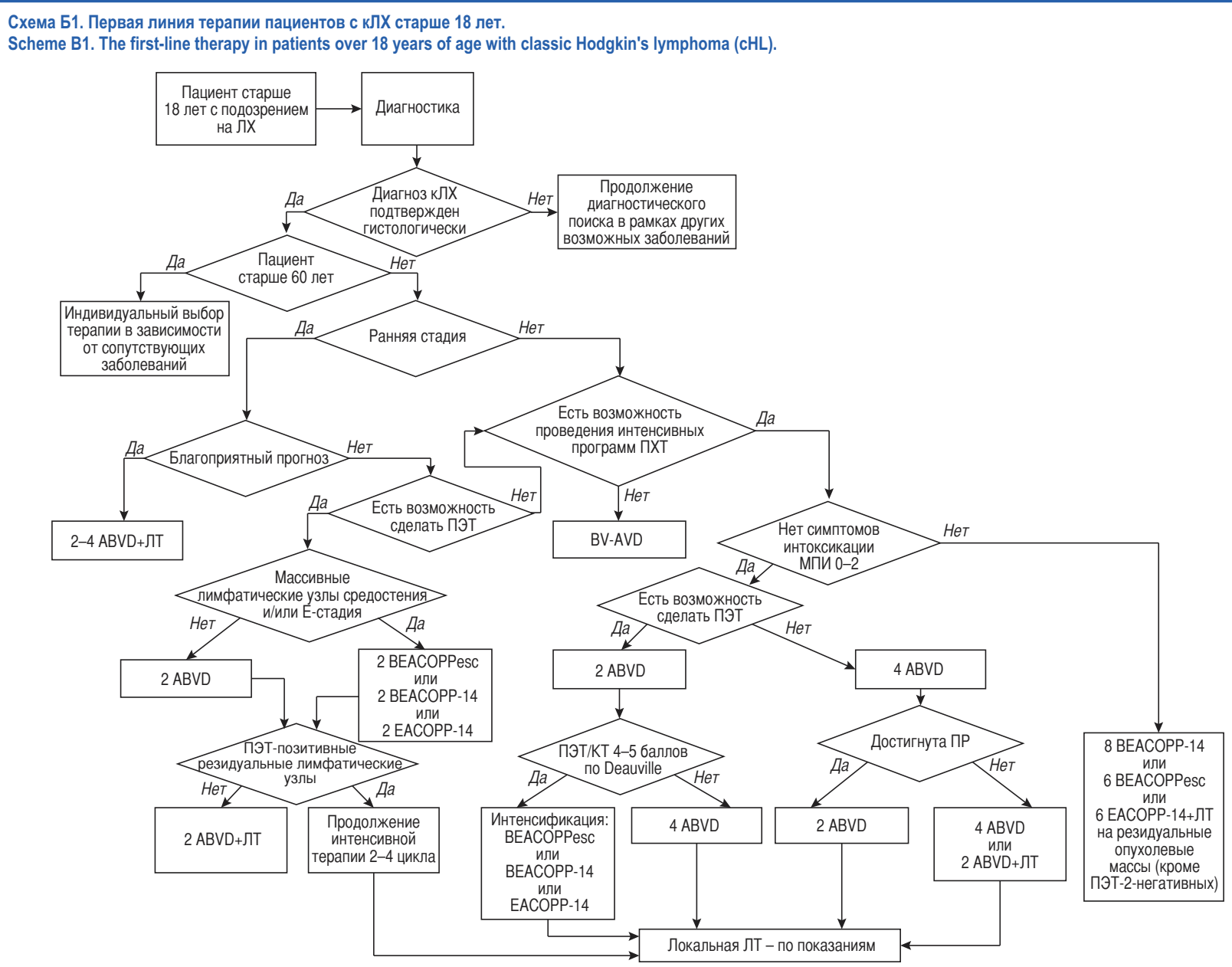


Схема Б2. Первая линия терапии детей и подростков до 18 лет с кЛХ.

Scheme B2. The first-line therapy in children and adolescents under 18 years of age with $\mathrm{cHL}$.
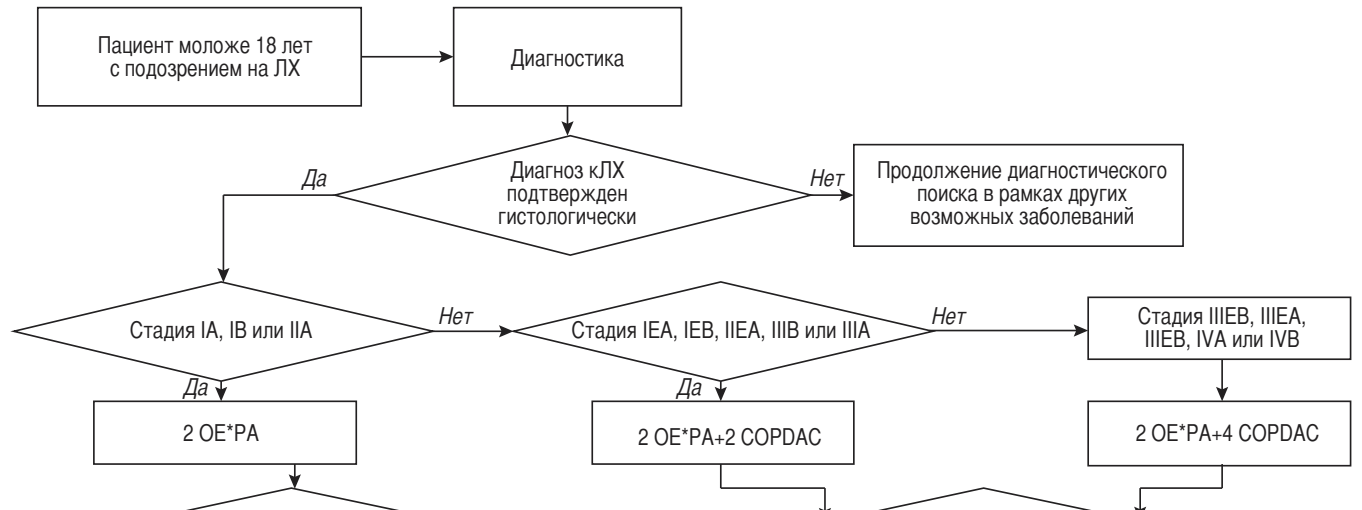

После 2 циклов ОЕ*РA

по данным ПЭТ/КТ определяется
метаболически активная $\quad \begin{gathered}\text { по данным ПЭТ/КТ определяется } \\ \text { метаболически активная }\end{gathered}$

метаболически активная

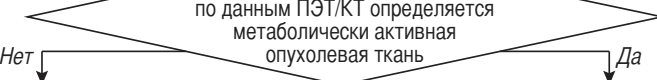

1 COPDAC

опухолевая ткань

ЛТ

Схема БЗ. Лечение рецидивов кЛХ.

Scheme B3. Treatment algorithm for relapsed cHL.

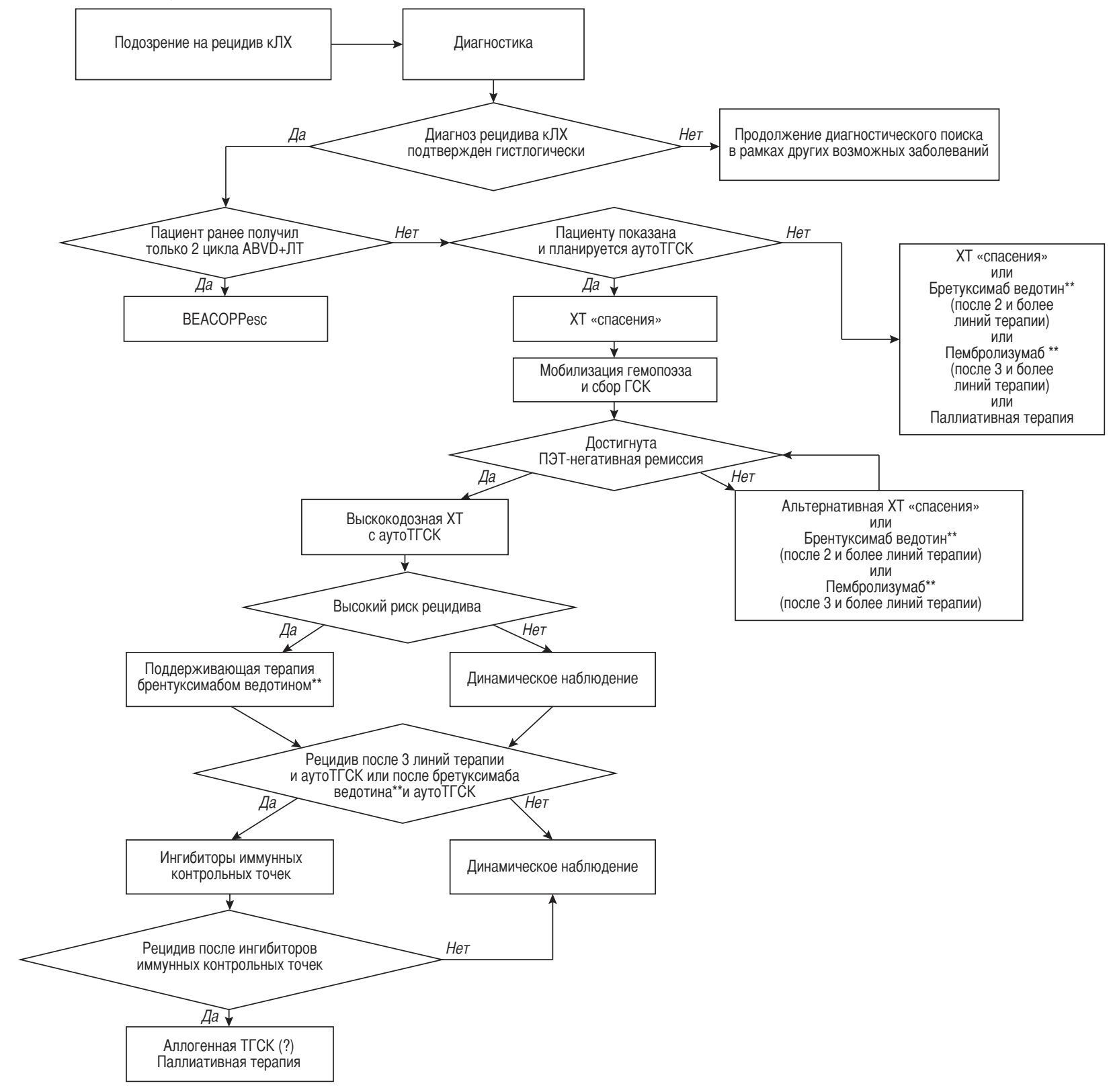




\section{Приложение В. Информация для пациентов}

Лимфомы - это опухоли из лимфоидных клеток. Лимфома - не одна болезнь, это большая группа, включающая более 30 разных заболеваний, которые отличаются друг от друга по своим проявлениям, по течению, по ответу на лечение. Лимфомы ведут себя и лечатся совершенно по-разному. Поэтому просто слово «лимфома» ни о чем не говорит - чтобы понимать, как лечить, надо знать конкретный вариант лимфомы.

ЛХ болеют в любом возрасте, но наиболее часто заболевание встречается у молодых людей, пик приходится на возрастной период от 16 до 34 лет. Люди старшего возраста, особенно те, кому больше 55 лет, также могут заболеть ЛХ.

Диагноз ЛХ устанавливается только после исследования пораженной ткани, полученной при биопсии. Диагноз подтверждается, только если обнаружены типичные клетки, называемые клетками Березовского-Штернберга-Рид. В последние годы диагностика ЛХ и других лимфом улучшилась, благодаря использованию нового метода, иммунофенотипирования, позволяющего точно идентифицировать опухолевые клетки по маркерам на их поверхности. Этот метод исследования очень важен для правильного выбора терапии, особенно в тех случаях, когда необходимо использовать узконаправленные (таргетные) препараты и иммунотерапию. ЛХ изучена лучше любого другого типа лимфом. К счастью, при современных методах лечения более 80\% заболевших ЛХ полностью излечиваются от этой болезни.

Специфических, характерных только для этого заболевания симптомов нет. Схожие жалобы и признаки могут быть при многих других заболеваниях. Нередко заболевание начинается как бы с простуды, респираторной инфекции, которая почему-то затягивается. Заболевание может начинаться с безболезненного увеличения лимфатических узлов.

\section{Приложение Г}

\section{Приложение Г1. Шкала оценки общего состояния пациента Восточной объединенной онкологической группы (ECOG)}

Оригинальное название: The ECOG Scale of Performance Status.

Источник: Oken MM et al. Toxicity and response criteria of the Eastern Cooperative Oncology Group. Am J Clin Oncol 1982; 5 (6): 649-65 [87].

Тип: шкала оценки.

Назначение: клиническая оценка общего состояния пациента.

Содержание и интерпретация:

\begin{tabular}{|l|l|}
\hline $\begin{array}{l}\text { Статус } \\
\text { (баллы) }\end{array}$ & Описание общего состояния пациента \\
\hline 0 & $\begin{array}{l}\text { Пациент полностью активен, способен выполнять все, } \\
\text { как и до заболевания }\end{array}$ \\
\hline 1 & $\begin{array}{l}\text { Пациент не способен выполнять тяжелую, но может } \\
\text { выполнять легкую или сидячую работу } \\
\text { например, легкую домашнюю или канцелярскую работу) }\end{array}$ \\
\hline 3 & $\begin{array}{l}\text { Пациент лечится амбулаторно, способен } \\
\text { к самообслуживанию, но не может выполнять работу. } \\
\text { Более 50\% времени проводит активно - в вертикальном } \\
\text { положении }\end{array}$ \\
\hline 5 & $\begin{array}{l}\text { Пациент способен лишь к ограниченному } \\
\text { самообслуживанию, проводит в кресле или постели } \\
\text { более 50\% времени бодрствования }\end{array}$ \\
\hline 5 & $\begin{array}{l}\text { Инвалид, совершенно не способен к самообслуживанию, } \\
\text { прикован к креслу или постели }\end{array}$ \\
\hline Смерть пациента \\
\hline 4
\end{tabular}

Наиболее распространенные признаки ЛХ:

- безболезненное увеличение лимфоузлов;

- лихорадка, которая не объясняется инфекцией или другими причинами и которую не удается устранить с помощью антибиотиков;

- потливость, особенно по ночам (мокрая подушка по утрам);

- необъяснимая потеря массы тела;

- необычная утомляемость и слабость.

Самый частый симптом ЛХ - увеличение лимфатических узлов, чаще на шее, реже в других областях тела. Температура обычно в пределах $37,5^{\circ} \mathrm{C}$ по вечерам. Очень характерно обильное потоотделение по ночам, хотя этот симптом трудно оценивать: летом жарко, зимой сильно топят. Могут наблюдаться многочисленные другие жалобы и признаки, связанные с тем, где находится очаг опухоли. Болей, как правило, не бывает. При локализации болезни в средостении, ближе к грудине, возможен дискомфорт за грудиной. У небольшого числа пациентов возникает мучительный, до расчесов кожный зуд. Около 5\% пациентов отмечают боли в увеличенных лимфоузлах после приема алкоголя. Это редкий симптом, но он характерен для ЛХ. Причина его неизвестна.

Более 80\% всех пациентов с ЛХ могут быть вылечены, причем обследования и лечение осуществляются в основном амбулаторно. Большинство пациентов получают комбинированную терапию, включающую ХТ в сочетании с ЛТ. В определенных обстоятельствах применяется высокодозная терапия и трансплантация костного мозга или стволовых клеток. ЛТ как единственный метод лечения в настоящее время не используется практически никогда.

\section{Приложение Г2. Шкала визуальной оценки ПЭТ-данных}

Оригинальное название: The Deauville ëve point scale

Источник: Meignan M et al. Report on the First International Workshop on Interim-PET-Scan in Lymphoma. Leuk Lymphoma 2009; 50 (8): 1257-60 [88].

Тип: шкала оценки.

Назначение: оценка результатов ПЭТ/КТ-исследования Содержание и интерпретация: для стандартизации, воспроизводимости и возможности сравнения результатов ПЭТ/КТ, полученных в различных медицинских учреждениях, при оценке эффективности лечения у пациентов с лимфомами используется визуальный анализ ПЭТ-данных по 5-балльной шкале [88]. При этом интенсивность накопления 18F-фтордезоксиглюкозы в патологическом очаге сравнивается с интенсивностью накопления препарата в неизмененных отделах средостения или в правой доле печени:

- 1 балл - характеризуется отсутствием накопления препарата в определяемом ранее патологическом очаге;

- 2 балла - накопление препарата в патологическом очаге не превышает по интенсивности накопление препарата в неизмененных отделах средостения;

- 3 балла - накопление препарата в патологическом очаге выше, чем в средостении, но не превышает накопление препарата в правой доле печени;

- 4 балла - накопление препарата в патологическом очаге несколько выше, чем в печени;

- 5 баллов - накопление препарата в патологическом очаге значительно выше, чем в печени, или определяется появление новых патологических очагов, связанных с заболеванием.

Также введено понятие Х-баллов, характеризующих наличие очагов накопления 18F-фтордезоксиглюкозы неясного, скорее воспалительного генеза, связь которых с основным заболеванием маловероятна.

Интерпретация результатов ПЭТ по шкале Deauville проводится комплексно с учетом клинических и исходных ПЭТ-данных, этапа лечения, а также других показателей ответа на лечение. 